\title{
Franciszek Wawrzyniak
}

\section{Erekcja Domu sióstr miłosierdzia w szpitalu św. Aleksandra w Kielcach w r. 1862}

Prawo Kanoniczne : kwartalnik prawno-historyczny 10/1-2, 221-287

1967

Artykuł został zdigitalizowany i opracowany do udostępnienia w internecie przez Muzeum Historii Polski w ramach prac podejmowanych na rzecz zapewnienia otwartego, powszechnego i trwałego dostępu do polskiego dorobku naukowego i kulturalnego. Artykuł jest umieszczony w kolekcji cyfrowej bazhum.muzhp.pl, gromadzącej zawartość polskich czasopism humanistycznych i społecznych.

Tekst jest udostępniony do wykorzystania w ramach dozwolonego użytku. 


\section{Ks. FRANCISZEK W A W R Z Y N A K}

\section{EREKCJA DOMU SIÓSTR MIŁOSIERDZIA W SZPITALU SW. ALEKSANDRA W KIELCACH W 1862 ROKU}

Tręś ć: Wstęp. 1. Rys historyczny. 2. Erekcja Domu Sióstr Miłosierdzia. 3. Utrzymanie Domu, legaty. 4. Zakres pracy, ilość, mieszkanie szarytek. 3. Kaplica szpitalna, kapelan szpitala, spowiednicy Sióstr Miłosierdzia. 6. Zakończenie. Bibliografia.

\section{Wstęp}

Szpital w Kielcach, pod wezwaniem św. Aleksandra, istnieje od r. 1828. Opicke i zarząd sprawowała w nim bezpośrednio i na mocy prawa Rada Opiekuńcza Zakładów Dobroczynnych Powiatu Kieleckiego w zależności od Rady Głównej w Warszawie. Mieścił etatowo 50 łóżek; w rzeczywistości jednak liczba chorych dochodziła do stu. Usługi oddawali chorym posługacze i posługaczki.

Za przykładem innych miast Gubernii Radomskiej, jak Sandomierza i Kurozwęk, gdzie chorym w szpitalach służyły pomocą i opieką Siostry Miłosierdzia, róźne osobistości i instytucje starały się sprowadzić szarytki do szpitala św. Aleksandra w Kielcach. Najwięcej zasług na tym polu położył Administrator i Wikariusz Apostolski Diecezji Krakowsko-Kieleckiej, ks. Maciej Majerczak. Był on duszą całego przedsięwzięcia i jemu nieomal wyłącznie szpital kielecki sprowadzenie Sióstr Mił. zawdzięcza. Szczerze i z pożytkiem współdziałały z biskupem Majerczakiem Rada Opielsuńcza Zakładów Dobroczynnych Powiatu Kieleckiego, Rada Główna Zakładów Dobroczynnych w Królestwie Polskim, Marszałek Szlachty Gubernii Radomskiej, duchowieństwo Diecezji Krakowsko-Kieleckiej, które zapisało najwięcej legatów na uposażenie SS. Mił., oraz kieleckie społeczeństwo.

Sama myśl sprowadzenia szarytek do Kielc celem pielęgnowania chorych jest $\mathrm{z}$ góra całe sto lat starsza. Rzucił ją $\mathrm{w}$ r. 
1756 Kajetan Sołtyk, biskup krakowski. Gdy w tymże roku rozebrano drewniany kościółek św. Leonarda, wystawił Sołtyk na jego miejscu wielki gmach, zwany Leonardem, zastrzegając wyraźnie, aby przeznaczony był na szpital i na Dom SS. Mił. Nieprzewidziane wypadki plan ten unicestwiły. W r. 1800 w czasie wielkiego pożaru, gdy prawie całe Kielce spłonęły, spalił się również gmach Leonarda. Odbudowany i odnowiony w r. 1809, służył juź innym celom. Od r. 1816 mieścił biura Komisji Województwa Krakowskiego, a w późniejszych latach urządzono w nim szpital wojskowy.

\section{Rys historyczny}

Myśl oddania szarytkom opieki nad chorymi w szpitalu św. Aleksandra i erekcji Domu SS. Mił. w Kielcach, powziął w r. 1855 Administrator i Wikariusz Apostolski Diecezji Krakowsko-Kieleckiej, ks. Maciej Majerczak ${ }^{1}$.

$\mathrm{Z}$ wielką energią, ze szczerą i realistyczną koncepcją działania, postanowił biskup zrealizować swe zamierzone działo.

Ostatecznym motywem do publicznego wystąpienia $\mathrm{z}$ projektem sprowadzenia SS. Mił., było ogłoszenie przez pap. Piusa IX dogmatu o Niep. Poczęciu N. M. P. ${ }^{2}$ Chciał bp Majerczak, aby dogmat ten połączyć konkretnie z życiem i uwiecznić go na swoim terenie przez czyn miłosierny, który by służył dobru ogólnemū, a odpowiadał intencjom Tej, która jest „Matką Miłosierdzia” i „Uzdrowieniem Chorych”. Gdy więc 8. XII. 1859 roku, nowa tę prawdę wiary we wszystkich kościołach diecezji głoszono, równocześnie $\mathrm{z}$ ambony Kolegiaty Kieleckiej ${ }^{3}$ podał kaznodzieja miejscowy do wiadomości wszystkich wolę oraz zarządzenie biskupa, by powierzyć szarytkom opiekę nad chorymi w szpitalu kieleckim, oraz, by na fundusz potrzebny na ten cel, przeznaczyć ofiary jednej ze

\footnotetext{
${ }^{1}$ Ks: Maciej Majerczak ur. się 23. XI. 1800 roku w Ofalu w starostwie spiskim. Był Administr. i Wikar. Apost. Diecezij Krakowsko-Kieleckiej od r. 1849 do 1870 tj. aź do śmierci. Konsekrowany w Warszawie na biskupa jerychońskiego $w$ r. 1862. Diecezja jego powstała z części diec. krakowskiej, położonej w Królestwie Kongresowym pod nazwą Wikariatu Apostolskiego. Przyjęta powszechnie nazwa Diecezji Krakowsko-Kieleckiej datuje się od r. 1842 i przetrwała do 5. I. 1882, tj. do przywrócenia przez Stol. Apost. samoistnej Decezji Kieleckiej; Rząd rosyjski już wcześniej Ukazem $z$ dn. 26. XII. 1865 roku uznał część Diec. Krak., leżącą w Królestwie Kongresowym, za oddzielną decezję.

2 Bullą ,Ineffabilis Deus" w r. 1854.

3 Kolegiata Kielecka wyniesiona została do godności katedry wpierw przez pap. Piusa VII bullą $z$ dn. 15. VI. 1805 roku, następnie bullą apostolską z an. 5. I. 1882 roku.
} 
skarbon kolegiaty aż do czasu zebrania wystarczającej kwoty zakładowej. Było to formalne zapoczątkowanie nowego dzieła.

Przez sześć $z$ góra lat niezmordowanie odtąd pracować będzie bp Majerczak dla tego umiłowanego przedsięwzięcia. Nie szczędzi zabiegów, sił, własnych funduszów; w trudnościach wykazuje święty upór i zaparcie. Inicjuje, przyspiesza i wykonuje wszystkie prace przygotowawcze. Kieruje i sam układa prawie całą korespondencje, zwracając ją wszędzie, gdzie tylko obudzić może zrozumienie i poparcie. Nie mogąc własną wyłączną władzą oddać szarytkom szpitala, stale organom nad Instytucjami Dobroczynnymi w kraju czuwającym, przypomina i podsuwa sposób formalnego działania, przesyłając im gotowe, wypracowane akta do aprobaty Rządu. Znosi się bezpośrednio z Władzami Rządowymi Królestwa Polskiego w Warszawie, zwłaszcza w sprawach, dotyczących uposażenia nowego Domu, szuka prywatnie protekcji członków Rządu dla przyspieszenia biegu formalności urzędowych. Powagą biskupiego urzędu osobiście zbiera cały fundusz na uposażenie SS. Mił. Poważny to musiał być dorobek pracy, jeżeli „Synodus Dioecesana Kielcensis" ", podając w krótkiej charakterystyce najważniejsze wydarzenia za rządów poszczególnych Administratorów Diecezji Kieleckiej, podkreśla przy bpie Majerczaku sprowadzenie do Kielc SS. Mił.

Aby zapewnić sobie należytą sankcję działania, zniósł się z Radą Opiekuńcza Zakładów Dobroczynnych Powiatu Kieleckiego, która według swych kompetencji szpitalem zarządzania, oraz z Marszalkiem Szlachty Gubernii Radomskiej E. Niemojewskim. Przekonany, że z żadnym sprzeciwem $z$ tej strony się nie spotka, nie czekając na odpowiedź, szuka sposobów, aby wyjednać zapisy i legaty, stanowiące podstawę $i$ bezwzględny warunek sprowadzenia szarytek. W goracych apelach, nacechowanych serdeczną wylewnością i namaszczeniem, zwraca się skutecznie do okolicznych ziemian, a przede wszystkim do zamożnych proboszczów swej diecezji. Korespondencja, jaką w tym przedmiocie prowadził bp Majerczak ze swoimi kapłanami, świadczy dobitnie o wspaniałym podejściu, pełnym ludzkich i nadprzyrodzonych pobudek, o szacunku dla proboszczów onaz o wielkiej ofiarności duchowieństwa. Potwierdza też wymownie ustaloną opinię, że gdziekolwiek zawiązywało się i dojrzewało dzieło miłosierdzia, tam Kościół Katolicki w osobach swoich pasterzy służył światłą radą, okazywał głębokie zrozumienie, a nade wszystko moralną i materialną pomoc.

4 Z r. 1927. 
Oto $\mathrm{m}$. in. charakterystyczne odręczne pismo ks. biskupa Majerczaka do emeryta, b. proboszcza w Szkalbmierzu, ks. Bartłomieja Jarzębskiego z dnia 17 maja 1859 roku:

„Wielmożny Księże Dobrodzieju.

Poważanie, jakie W.X. Dobrodziej umiałeś zyskać u Duchowieństwa, daje mi rękojmię szlachetności uczuć Jego. Chętna pomoc, $\mathrm{z}$ jaką $\mathrm{w}$ czase nabożeństw wiekkszych przybywasz $\mathrm{W}$. Pan spowiadać lud Boży, choć włos ubielony i wiek poważny, wskazuje, że nosisz $\mathrm{w}$ pamięci i sercu wage powołania kapłańskiego. Dlatego $\mathrm{z}$ zaufaniem do W. $\mathrm{X}$. Dobrodzieja $\mathrm{z}$ prośbą się odzywam.

Blogosławił Bóg pracy Twojej $\mathrm{W}$. Panie tak obficie, że należysz dzisiaj do najzamożniejszych kapłanów w Diecezji. Dziś uwolniwszy się sprzedażą wioski powiatowej od kłopotów obywatelskich, mniemam, że majątkowi swemu nadasz takie przeznaczenie, iż nie tylko wesprzesz rodzinę swoja, ale Panu Bogu złożysz dowód wdzięczności ze zbudowaniem tych, co w każdej chwili na stan kapłański gotowe mają zarzuty.

Oto $w$ szpitalu kieleckim najistotniejszej nie dostaje rzeczy, bo Sióstr Milosierdzia, bez których obsługa około chorych nigdy ani sumienną ani wygodną być nie może. Od lat trzech zbierają się składki na zapewnienie tego dobrodziejstwa $\mathrm{w}$ szpitalu rzeczonym, a rezultat dotychczasowy pokazał 17000 złp., suma zaś, odpowiadająca celowi, najmniej złp. 90000 wynosić powinna. Licząc przecież na miłosierdzie Boże a szlachetność ludzkă, już w zamierzonej sprawie zniosłem sie $z$ Wizytatorem XX. Misjonarzy. Sam co mogłem dałem ${ }^{5}$ i jeżeli mam odkryć prawdę, wyczerpawszy do dna mój fundusz, uciec się muszę do innych. Jakieś przeczucie skierowało myśl moją do W.X. Dobrodzieja $\mathrm{z}$ prośbą o ofiarę $\mathrm{w}$ powyższym celu. Ale nie ja wyciagam rękę do Szan. Pana; to Chrystus ubogi i chory, który Ci blogasławił na zamożności i zdrowiu i poważnych latach i który jeszcze ma w ręku Swoim dla Ciebie Panie cała wieczność szczęcia, przekraczającego wszystkie skarby ziemi, ważniejszego nad posiadanie całego świata. Raczże W. X. Dobrodzieju nie zawieść nadziei Zbawiciela, jaka On w Tobie pokłada. Uzacnisz imię Twoje, staniesz się wzorem dla drugich, odnowisz pamięć Konfratrów dawnych, co gdziekolwiek uzbierany pieniądz składali na Bożą chwałe a wsparcie ludzi. Ale cō najpożądańsze, że po najdluższym życiu Twoim Panie, może Ci w ostatniej chwili Chrystus, któremu w ubogich i chorych troskliwszą zapewniłeś ofiarą swoją obsługę, Sam ojcowską ręką łagodnie przychyli oczy, a dusze Twoją za czyn miłosierdzia laska zbawienia uszczęsliwi. Ten Chrystus, Panie, oczekuje na błogi skutek prosby - Boga, którego piastujesz na rękach, pewnie odmową nie zasmucisz." ".

I odpowiedź odbiorcy:

„J. Wielmożny Panie.

Wskutek reskryptu z dnia 17 maja b.r., niemniej wielce dla mnie Szanownego własnoręcznego pisma J. Wnego Pana, okazanego przez $\mathrm{X}$. kanonika Strondałło, mam zaszczyt w załączeniu przesłać rubli 1500 , czyli 10000 złotych polskich, na wieczny fundusz na załóżyć

51500 Rubli, czyli 10000 złotych polskich.

- Akta Konsystorskie Tom I. 
się mający Instytut Sióstr Mił. w Kielcach przy szpitalu tamecznym. - Nie umiem znaleźć wyrazów na podziękowanie J. W. Panu za szczególną jego dla mnie łaskawość. Odezwy te trafiły do mego serca i przekonania. Rzeczywiście dozwolił mi Pan Bóg przy zdrowym rozsądku, pracy i rządności, zebrać mająteczek, abym na starość, kiedy siły fizyczne już nie wystarczają do pracy w obowiązkach parafialnych, nie obciążał funduszu kościoła, przy którym lat $30^{1 / 2}$ byłem proboszczem, który to mająteczek chciałbym pożytecznie użyć, aby oprócz rozumnego wsparcia mojej biednej rodziny, zostawić kościolom i cierpiącej Iudzkości pamiąteczkę, w czym J. W. Panie jesteś dla mnie i przykładem i silną pobudką. Niech Pan nieśmiertelności w najodleglejszą przyszłość przedłuża czerstwe zdrowie J. W. Pana, tyle dla dobra religii i Towarzystwa potrzebne i niech nieustannie opatrywać raczy Swój Kościół podobnymi Diecezji Pasterzami. - A teraz racz J. W. Panie przyjąć wyrazy głębokiego szacunku i uwielbienia od starego weterana i Jego najniższego sługi ?.

$\mathrm{X}$. Bartłomiej Jarzębski, były proboszcz w Szkalbmierzu a teraz Członek czynny Towarzystwa Rolniczego w własnej siedzibie w Stawiszycach osiadły."

Tak Rada Opiek. w Kielcach, jak Marszałek Szlachty z. całą przychylnością i uznaniem do projektu X. Majerczaka się odnieśli. W dwukrotnych odpowiedziach Rada doniosła, że „Instytucję tę $z$ całą chęcią zaprowadzić jest gotowa" 8 , że ,,szczerze pragnie sprowadzenia SS. Mił. i wszelkich ze swej strony dołoży do tego starań" 9, byleby odpowiednie fundusze na to pozwoliły. Wprawdzie dla powiększenia ich nic Rada nie uczyniła, nie zasiliła ich ani własnym kapitałem, bo go nie miała, ani zabiegów $w$ tej nieprzyjemnej dziedzinie nie wykazała; niemniej przez swe chęci i gorliwość dla rzeczy samej, dawała Władzy Klnej urzędowe oparcie. Prezydujący Radzie Pow. Erazm Różycki, chociaż „,najzacniej, najkorzystniej i najgorliwiej, prawdziwie po chrześcijańsku i z głębokim rzeczy przejęciem urząd swój spełnia" ${ }^{10}$, żadnego działania w kierunku zebrania funduszów nie podejmuje. Prosi tylko ks. Majerczaka o zwrócenie się do Marszałka Szlachty, aby ten większą sumę od Rządu wyjednał.

Tymczasem Marszałek E. Niemojewski, świadom swego stanowiska reprezentowania Polaków Gubernii Radomskiej wo-

7 Tamże.

8 Tamże, pismo Rady Pow. do bkpa $\mathrm{z}$ đn. 10. V. 1857 roku.

- Tamże, pismo Rady Pow. do bkpa $z$ dn. 3. II. 1859 roku.

10 Słowa bkpa Majerczaka $w$ piśmie $z$ dn. 8. III. $1860 \mathrm{r}$. do Laszczyńskiego, Prezesa Rady Głównej Zakładów Dobroczynnych w Królestwie Polskim.

15 - Prawo Kanoniczne 
bec Wladz Rosyjskich i Instytucjom Dobroczynnym bardzo oddany, w odezwie $z$ dnia 7. IV. 1857 roku, skierowanej do bpa Majerczaka, daje się poznać jako wielki zwolennik i przyjaciel szarytek. Rad by już je widzieć w szpitalu kieleckim mimo braku właściwych środków na ich utrzymanie. Chwali SS. Mił. i podaje motywy, dla których jedynie im należy oddać opiekę nad chorymi:

„Tylko te świątobliwe kobiety przez poświęcenie swoje i wrodzone im uczucie dla cierpiących, moga z całą troskliwością pielęgnować chorych i osładzać niedolę ubóstwa. Ich zajmowanie się osobiste opatrywaniem ran, podawanie lekarstw, moralno-religijne ożywienie ducha upadającej nadziei cierpiącego, przy tym ich rząd na gospodarność domową i zarazem latwość nagięcia się do warstw towarzystwa, nieprzeniknionego jeszcze egoizmem i powszechnym zepsuoiem, odgrywa tu najważnejszą rolę, zjednywa zaufanie i sympatię ogólu, a tym samym sprowadza wsparcie materialne, bez którego zakłady prowincjonalne istnieć by nie mogły. Dlatego teź widzimy, że te tylko Zakłady Dobroczynne zaszczycają się prawdziwą pieczolowitością i otoczone sa poszanowaniem ogólu, w których znajduja się Siostry Miłosierdzia" "1.

Niemniej Marszałek Niemojewski stwierdza trudności natury finansowej, wysunięte przez $X$. Majerczaka $i$, nie wiele o tym wspominając, żadnego sposobu rozwiązania ich nie podaje. Proszony, aby do obywateli ziemskich skierował odpowiednie wezwanie i sam poparl je wlasnym przylkładem, oraz, by wpływem swoim w Rządzie znaczniejszą kwotą ${ }^{12}$ fundusz zakładowy powiększył, w odpowiedzi zapewnia tylko biskupa, że otrzymał poufnie obietnicę pozytywnej decyzji Władz Wyższych. „Jak w każdym razie tak i tu dobroczynny $i$ dbały o dobro mieszkańców Rząd" 13, chociaż pomocą materialną służyć nie może, nie odbiega od samego zatwierdzenia szlachetnego przedsięwzięcia. W rezultacie przyrzekł Marszałek Szlachty jedynie moralne poparcie u Rządu, a caly projekt poleca X. Majerczakowi i duchowieństwu, ,albowiem od nikogo pewniej jak od sług ołtarza" 14 "doprowadzenie do skutku tak błogich zamiarów nie zależy" ${ }^{25}$.

11 Akta Kons. Tom I, z pisma Marszałka Szlachty do Biskupa Majerczaka $\mathrm{z}$ dn. 7 . IV. 1857 roku.

12 Fundusz zakladowy najmniej wynosić winien 11250 rubli, czyli 75000 złotych polskich.

13 Akta Kons. Tom I, z pisma Marszalka Szlachty do Biskupa Majerczaka $z$ dn. 21 . I. 1858 roku.

${ }_{14}$ Tamże $\mathrm{z}$ pisma Marszałka Szlachty do biskupa Majerczaka $\mathrm{z}$ dn. 7. IV. 1857 roku.

${ }_{15}$ Tamże, z pisma Marszalka Szlachty do biskupa Majerczaka $z$ dn. 21. I. 1958 roku. 
Nie mógł mieć bp Majerczak żadnej nadziei na jakąkolwiek pomoc finansową ze strony Instytucji Krajowych i Władz Państwa. Pozostawiony własnej tylko w tym względzie inicjatywie i własnym zabiegom, ponawia apele do proboszczów, u których znajduje pełne zrozumienie i poparcie. Skutki są widoczne. Mnożą się zapisy na szarytki i już 8 maja 1860 roku fundusz zakładowy wynosił wystarczającą na sprowadzenie pięciu sióstr sumą 75000 złp., czyli 11250 rubli. Tym samym najważniejsza przeszkoda w realizacji zamierzonego dziela została usunięta.

$\mathrm{Na}$ prośbę Kieleckiej Rady Opiek. zwraca się X. Majerczak do Dyrektora XX. Misjonarzy i do Domu Prowincjonalnego SS. Mił. w Warszawie. Donosi o zamiarze sprowadzenia szarytek do szpitala w Kiclcach, prosi o podanie warunków, zwłaszcza kosztów utrzymania i potrzebnej ilości zakonnic. Wizytatorka Prowincji Warszawskiej Joanna Schwarz oświadcza dn. 5. I. 1860 roku, ,że SS. Mił. z całą przychylnością gotowe są poświęcić się na obsługiwanie chorych i biednych członków w szpitalu kieleckim, szukając zawsze czasu i miejsca sposobnego do dopełnienia dzieła świętego stanu" ${ }^{16}$. Czyni zastrzeżenia i uwagi, dotyczące chorych wenerycznie, intendenta, kaplicy i kapelana, oraz nadmienia, że siostry w liczbie pięć osób obejmą nowa placówkę tuż po odpowiednim wniosku Pow. Rady Opiekuńczej, zarządzającej szpitalem.

Mając potrzebne fundusze, życzliwe stanowisko Pow. Rady Opiekuńczej i Marszałka Szlachty, oraz przychylną odpowiedź S. Wizytatorki, wstępuje biskup na droge oficjalną. Kieruje pismo do Laszczyńskiego, prezesa Rady Głównej Zakładów Dobroczynnych w Królestwie Polskim, donosząc, że wszystko do sprowadzenia szarytek jest gotowe ${ }^{17}$. Przedkłada cały swój plan, wyszczególnia legaty i sposób zarządzania nimi, porusza chorych wenerycznie, sprawę intendenta, prosi o dopuszczenie kapłanów w liczbie 5-7 jako członków Pow. Rady Opiek. i o szybkie dopełnienie dzicła. Prezes Laszczyński daje ostatnie wskazania ${ }^{18}$, w myśl których Rada Opiekuńcza Kielecka przez swego przewodniczącego Erazma Różyckiego, zawiera dn. 11. VI. 1860 roku, wieczysta umowę z S. Wizytatorką, a ta przyjmuje $\mathrm{w}$ formie notarialnej akceptacje darowizn prawnie zeznanych. Do akt tych dołącza bp Majer-

\footnotetext{
${ }_{16}$ Akta Kons. Tom I.

$17 \mathrm{~W}$ dniu 8. III. 1860 roku. Por. Akta Kons. Tom I.

${ }^{18} \mathrm{~W}$ piśmie do biskupa Majerczaka $\mathrm{z}$ dn. 4. IV. 1860 roku. Por. Akta Kons. Tom. I.
} 
czak zezwolenie na sprowadzenie do Kielc SS. Mił., oraz akt erekcji $z$ dn. 10. VIII. 1860 roku i wszystkie cztery dokumenty wręcza dn. 29. VIII. 1860 roku Pow. Radzie Opiek. z prośbą, aby ta jak najwcześniej przesłała je $\mathrm{z}$ prośbą o zatwierdzenie do Rządu przez Radę Główną w Warszawie i w ten sposób do urzeczywistnienia przedsięwzięcia przystąpiła. Równocześnie $\mathrm{X}$. Majerczak informuje ${ }^{19}$ prezesa Laszczyńskiego o wysłaniu do Rządu wszelkich akt, prosi o poparcie i szybkie działanie: ,pragnę i błagam, abyśmy na zatwierdzenie długo nie czekali. Może J.W. Pan zechce łaskawie prosić Władze Rządowe o spieszniejsze $\mathrm{w}$ przedmiocie tym działanie, bo rad bym z serca, aby na dzień 8 grudnia b. r. już Siostry Miłosierdzia do szpitala wprowadzone zostały" 20.

Wydawało się, że najbliższe tygodnie przyniosa zatwierdzenie przez Rząd aktu erekcyjnego. Żadna uzasadniona trudność nie pozwalała sądzić inaczej. Pow. Rada Opiekuńcza bezzwłocznie przesłała go Radzie Głównej, a ta Komisji Rządowej W. R. i O.P. w Warszawie.

Mijają miesiące, zbliża się 8 grudnia 1860 roku, dzień przewidziany przez Wladzę Duchowna na wprowadzenie szarytek do szpitala; zatwierdzenia jednak nie ma. Powodem zwłoki nie może być ani Pow. Rada Opiekuńcza, która każdą myśl bpa Majerczaka przyjmuje, razem z nim się niepokoi i publicznie daje powody radości $\mathrm{z}$ powodu wykończenia - zda się - wszystkich przygotowań, ani Rada Główna, która przez prezesa swego sławi postać biskupa za jego wysokie pojęcie o obowiązkach posterza Diecezji i obywatela Kraju, ,wykonującego religię iw uczynkach" "21, tym więcej, że sama formę załatwienia sprawy podala i na miejscu $\mathrm{w}$ Warszawie wobec Władz Rządowych obiecała jej dopilnować. Najprawdopodobniej akta wszystkie ugrzęzły w Komisji Rządowej W. R. i O. P., gdzie albo przez zapomnienie, albo celowo nie są rozpatrywane. Nie pozostało nic innego, jak zapukać do wpływowych osób w Rządzie, interesom Polaków życzliwych; inaczej cały projekt mógłby utknąć na martwym punkcie, a przez długotrwałą zwłokę $i$ trudności, jakie czas z sobą niesie, ulec likwidacji. Tego obawiał się biskup. Dlatego po przeszło trzech kwartałach od wysłania po zatwierdzenie aktu erekcyjnego, $\mathrm{w}$ dniu 24. VI. 1861 roku, szuka protekcji u hr. Wielopol-

\footnotetext{
$19 \mathrm{~W}$ piśmie $z$ dn. 31. VIII. 1860 roku. Por. Akta Kons. Tom I.

20 Akta Kons. Tom I, z pisma bkpa Majerczaka do prezesa Laszczyńskiego $\mathrm{z}$ dn. 31. VIII. 1860 roku.

${ }_{21} \mathrm{~W}$ piśmie Laszczý́skiego do $\mathrm{X}$. Majerczaka $\mathrm{z}$ dn. 4. IV. 1860 roku. Akta Kons. Tom I.
} 
skiego: „Rzecz dziwna, że pomimo całej korzyści z Instytucji Sióstr Miłosierdzia, pomimo tak hojnego uposażenia, nie zostawiającego żadnej wątpliwości, pomimo wreszcie licznych korespondencji i osobistych zabiegów już przez delegowanych, już przeze mnie osobiście czynionych, po 10 miesiącach starań, nie otrzymano dotąd skutku $w$ powyższym przedmiocie. Jaśnie Wielmożny Panie! Ponieważ w tak świętej sprawie nie mogę spieszniejszego działania wyjednać, mam zaszczyt szukać protekcji J. W. Pana, nie tylko jako u Dyrektora Prezydującego w Komisji Rządowej W. R. i O.P., ale jako jednego z najwyższych dygnitarzy Kraju. Wszelkie usilniejsze wyrażenia uważam tu za zbyteczne - sam przedmiot mówi za sobą. Powaga i przekonanie J. W. Pana pewno go poprą stanowczo, a ja $z$ upragnieniem oczekiwać będę przychylnego słowa J. W. Pana" 22.

Siedem tygodni później kieruje bp pismo do Solnickiego, rzeczywistego Radcy Stanu w Komisji Rządowej W. R. i O.P. z zapytaniem, czy prośba, wystosowana do margrabiego Wielopolskiego, doszła do właściwych rąk; nie pomija przy tym sposobności, aby i jego sercu sprawę gorąco polecić. To zwrócenie się X. Majerczaka wprost do Komisji Ministerialnej, miało znaczenie decydujące. Odtąd roztrzygnięcia szybko padać będą. Komisja W. R. i O.P. jako pierwsza z centralnych Komisji Rządowych całe dzieło dokładnie rozpatrzyła i po przychylnym zaopiniowaniu przesłała dn. 9. X. 1861 roku wszystkie akta do Komisji Rządowej Spraw Wewnętrznych. Z upoważnieniem Dyrektora Głównego Komisji Rządowej W. R. i O. P. hr. Wielopolskiego, uwiadomił o tym bpa Majerczaka Dyrektor Wydziału tej Komisji Solnicki urzędowym dokumentem z dn. 9. X. 1861 roku: „Komisja Rządowa zawiadamia, iż po rozpoznaniu operatu, dotyczącego zaprowadzenia Sióstr Miłosierdzia przy szpitalu św. Aleksandra w Kielcach, takowy wraz ze swoją opinią zwróciła w dniu dzisiejszym Komisji Rządowej Spraw Wewnętrznych do dalszego $z$ nim postąpienia" 23. Z kolei rozpatrzyła akta Rządowa Komisja Sprawiedliwości. Wreszcie Rada Administracyjna Królestwa uchwałą z dn. 26. XI. 1861 roku właściwe dokumenty zatwierdziła. Wiadomość ta doszła do bpa Majerczaka droga urzędową. Uczyniła to Pow. Rada Opiek. ${ }^{24}$, która pismem Rady GłówTom I.

22 Z pisma bkpa Majerczaka do margr. Wielopolskiego, Akta Kons.

${ }_{23}$ Akta Kons. Tom I.

$24 \mathrm{~W}$ dn. 23. XII. 1861 roku. 
nej ${ }^{25}$ została o tym poinformowana, oraz upoważniona do przyjęcia SS. Mił. i powierzenia ich opiece chorych w szpitalu kieleckim. W ten sposób formalnościom wszystkim stału się zadość.

Niemniej w ostatniej chwili na gruncie miejscowym jakieś trudności wylonić się musiały, skoro szybki w działaniu i z utęsknieniem wyglądają̧cy rządowego zatwierdzenia bkp Majerczak, dopiero po 9 tygodniach skomunikował się z Władzami Domu Prowincjonalnego SS. Mił. w Warszawie ${ }^{26}$. Równocześnie, wybiegając zawsze $z$ inicjatywą, na ręce $\mathrm{S}$. Wizytatorki przesłał zastrzeżoną kontraktem ${ }^{27}$ sumę 500 rubli czyli 3333.10 złotych polskich, przeznaczoną na koszt przejazdu i pierwsze na miejscu zagospodarowanie sióstr. Gdy Rada Opiek. Powiatowa na mocy prawa swego wyznaczyła termin oddania siostrom szpitala św. Aleksandra na 13 maja 1862 roku, wizytatorka Joanna Schwartz, po uprzedzeniu bkpa Majerczaka, wyruszyła z Warszawy do Kielc w dniu 11 maja wieczorem wraz z pięcioma siostrami. Dzień 13 maja stał się prawdziwie świętym całych Kielc. Powitanie sióstr i wprowadzenie ich $\mathrm{w}$ urząd odbyło się wśród ceremoniału wszystkich możliwych funkcji kościelnych, oraz $\mathrm{z}$ honorami ze strony miejscowych Instytucji Dobroczynnych i społeczeństwa ${ }^{28}$. Od południa tego dnia były szarytki na swych posterunkach.

\section{Erekcja domu sióstr milosierdzia}

Równocześnie z zamiarem sprowadzenia SS. Mił. do szpitala św. Aleksandra w Kielcach, wyłoniła się dla inicjatorów trudność natury formalnej, godząca w samą istotę przedsięwzięcia. Ukaz Najjaśniejszego Pana z 2. III. 1842 roku, dotychczas obowiązujący, oddał zarząd wszystkich Instytucji Dobrocznnych, $\mathrm{w}$ tym także szpitali, jedynie władzy świeckiej z wyłączeniem wszelkiego innego wpływu. Do tejże władzy świeckiej należało wyłącznie administrowanie majątkiem szpitali. Na żadne wyjątki nie pozwalał rygor przepisów państwowych; one ustalały liczbę osób, tworzących wewnętrzny zarząd poszczególnych szpitali, skład i zakres pracy zarządu zewnętrznego, którym dla powiatu była Radą Opiekuńcza Zakładów Dobroczynnych,

${ }^{25} \mathrm{Z} \mathrm{dn.} \mathrm{16.} \mathrm{XII.} 1861$ roku.

${ }^{26} \mathrm{~W}$ dn. 2. III. 1862 roku.

27 Art. 15. Umowy z dn. 11. VI. 1860 roku, zawartej między Pow. Radą Opiek. i S. Wizytatorką.

${ }_{28}$ Patrz następny rozdział, Erekcja Domu Sióstr Miłosierdzia. 
dla calego Królestwa zaś Rada Główna Zakładów Dobroczynnych. Przepisy państwowe oznaczały wysokość funduszów dla każdego szpitala i sposób zarządzania nimi. Ponadto każdy szpital miał oznaczone przez Radę Główną Opiekuńczą i przez Komisje Rządowe Spraw Wewnętrznych i Spraw Duchownych stałe etaty i odpowiednie na nie uposażenie.

Przy tak szczegółowej i ekskluzywnej ustawie rządowej niemożliwa była ani całkowita ani częściowa zmiana w zarządzaniu szpitalem na rzecz SS. Mił. Powiększyłaby to bowiem liczbę członków zarządu i rozchody z kasy szpitala, co wyraźnie było wzbronione. A gdyby nawet szarytki mogły objąć pracę $\mathrm{W}$ szpitalu $\mathrm{w}$ charakterze pielęgniarek $\mathrm{z}$ dodatkowym obowiązkiem zajęcia się kuchnią, spiżarnią i pralnią, szczupłe fundusze szpitalne, przez wyższe władze ściśle określone, stanowiłyby przeszkode nie do zwalczenia.

Liczne wyjaśnienia bkpa Majerczaka, Głównej i Powiatowej Rady Opiekuńczej, oraz Marszałka Szlachty doprowadziły do sprecyzowania stanowiska SS. Mił. w szpitalu św. Aleksandra $\mathrm{z}$ zachowaniem wszelkich przepisów prawa. Tak Marszałek Szlachty Niemojewski, jak prezes Rady Głównej Laszczyński, mając kontakty z czynnikami rządowymi, poznali ich opinię i otrzymali nieoficjalne zapewnienie, że Rząd chętnie widzi w szpitalach Siostry Miłosierdzia i zgadza się na powierzenie chorych ich pielegnacji; zastrzega tylko, że żadnych ciężarów $\mathrm{z}$ tego powodu ponieść nie może i nie pozwala nawet na najmniejsze na ten cel naruszenie funduszów szpitalnych. Poza tym zostawia Radzie Głównej swobodę działania i byleby tylko przedstawiła Rządowi odrębne, wystarczające fundusze na utrzymanie SS. Mił., z żadnym sprzeciwem się nie spotka. $\mathrm{Na}$ tej podstawie ustalono, że:

1. Rada Opiekuńcza Powiatu Kieleckiego nic ze swej prerogatywy rządzenia szpitalem nie traci. Do niej zatem należeć będzie cała administracja, korespondencja, rachunkowość, księgowość; siostry zaś zajmą się chorymi i domowym gospodarstwem.

2. Konieczny jest, niezależnie od ogólnego funduszu szpitalnego, oddzielny fundusz, przeznaczony wyłącznie na szarytki w sumie conajmniej 11250 rubli, czyli 7500 złotych polskich i pozostający pod zarządem Administratora Diecezji Krakowsko-Kieleckiej.

3. 'SS. Mił. w sprawach, dotyczących szpitala, pozostają pod zwierzchnictwem Pow. Rady Opiek. i „obowiązane są stosować się do praw, dekretów, postanowień i urządzeń, według któ- 
rych odbywa się zarząd szpitalny" ${ }^{29}$, poza tym podlegają biskupowi i władzom Zgromadzenia.

W ten sposób ustawa rządowa $\mathrm{z}$ r. 1842 została w calej rozciągłości respektowana.

Daleko łatwiej i prościej usunięto zastrzeżenia, które z kolei wysunęła S. Wizytatorka. Dotyczyły one oddziału chorych wenerycznie, które istniały przy szpitalu kieleckim i którego z przybyciem sióstr nie moźna było zlikwidować. Reguła zaś SS. Mił., przez św. Wincentego à Paulo ułożona, zakazywała oddawania posług przy tego rodzaju chorobach ze względu na ich obyczajowe podłoże, oraz $\mathrm{z}$ powodu zabiegów wprawdzie koniecznych, ale nie odpowiadających duchowi i delikatności zakonnej. Przepisu tego trzymały się szarytki ściśle w każdym innym szpitalu i nie mogły czynić wyjątku dla szpitala św. Aleksandra. W ramach zatem reguły zgodziły się szarytki przyjąć ogólny dozór i opiekę moralną nad chorymi wenerycznie, oraz dostarczać im potraw z kuchni i spiżarni, ale bez prania ich bielizny i bez opieki pielęgniarskiej, którą wykonywać mieli pielęgniarze i pielęgniarki.

Instytucją, upoważnoną $\mathrm{z}$ prawa do sprowadzenia SS. Mił. była Rada Główna Zakładów Dobroczynnych w Warszawie, zarządzająca szpitalami w całym Królestwie Polskim. Ona też bezpośrednio zabiegała u Rządu Królestwa o wyjednanie życzliwej w tym przedmiocie decyzji i o zatwierdzeniu potrzebnych funduszów. Do tejże Rady Głównej odniósł się biskup Majerczak 8. III. 1860 roku, która z kolei ${ }^{30}$ upoważniła Radę Opiek. Pow. Kieleckiego do formalnego działania i zażądała od niej następujących dokumentów:

1. Umowy Powiatowej Rady Opiekunczej z S. Wizytatorką. 2. Urzędowej przez notariusza sporządzonej akceptacji darowizn prawnie zeznanych. 3. Aktu erekcji $\mathrm{w}$ formie notarialnej. 4. Właściwego zezwolenia Administratora Diecezji.

Natychmiast Rada Powiatowa powiadomiła o tym X. Majerczaka, oraz specjalnym pismem $z$ dn. 11. VI. 1860 roku wydelegowała swego przewodniczącego, Erazma Różyckiego, do dopełnienia wszelkich formalności.

$\mathrm{W}$ tym samym dniu t. j. 11. VI. 1860 roku została zawarta umowa między Powiatową Radą Opiekuńczą i S. Wizytatorką Joanną Schwartz, określająca warunki pracy i wynagrodzenia pięciu szarytek. Urzędowe akta zeznania legatów od dłuższego czasu znajdowały się w rękach Administratora Die-

20 Art. 3 Umowy.

$30 \mathrm{~W}$ dn. 4. VI. 1860 roku. 
cezji, a dokonywane były wobec notariusza w terminach, w których ofiarodawcy poszczególne zapisy składali. $\mathrm{Za}$ datę sporządzenia ostatniego takiego aktu należy uważać dzień 8. III. 1860 roku ${ }^{31}$. Aktu akceptacji wszystkich darowizn dopełniła wobec notariusza S. Wizytatorka w kilku terminach, najpóźniej zaś 1. VIII. 1860 roku.

Erekcja domu SS. Mił. przy szpitalu św. Aleksandra w Kielcach stwierdzona została przez dwa oddzielne i niezależne akty. Jeden akt erekcji sporządzony zostal wobec notariusza łącznie przez Władzę Duchowną, oraz przez Radę Opiekuńczą Zakładów Dobroczynnych Powiatu Kieleckiego jako zwierzchność szpitalna i miał moc prawną wobec Władz Państwowych. Drugiego aktu erekcji dokonał sam Administrator Diecezji Krakowsko-Kieleckiej; była to zgoda rządcy Diecezji na utworzenie nowego Domu Zakonnego, wymagana przez prawo kościelne ${ }^{32}$. Większą wage $i$ znaczenie posiada pierwszy akt erekcji $\mathrm{i}$ to nie tylko $\mathrm{z}$ tego względu, ze zachowany został w całości, ale przede wszystkim dlatego, że wystylizowany i aprobowany przez obie Władze nad szarytkami w szpitalu, duchowną i świecką, ma szerszą podstawę i potrzebną zgodę ordynariusza diecezji bezpośrednio zaświadcza. Oto jego treść i brzmienie ${ }^{33}$ :

My Aleksander II Cesarz Wszech Rosji, Król Polski, etc. etc. etc.

Wiadomo czynimy, iż przed urzędnikiem naszym Rejentem Kancelarii Ziemiańskiej Gubernii Radomskiej, zeznany został akt osnowy następującej: Działo się w Kancelarii Ziemiańskiej Gubernii Radomskiej w Kielcach dnia dziesiątego sierpnia tysiąc osiemset sześćdziesiątego roku.

Przede mną Hilarym Kudlickim, Rejentem Kancelarii Ziemiańskiej Gubernii Radomskiej w Kielcach, przy Trybunale Cywilnym tejże Gubernii urzędującym, w mieście Kielcach zamieszkałym, stawili się osobiście:

1. Ks. Józef Gawroński ${ }^{34}$, kanonik honorowy lubelski, proboszcz w Dzierzgowie, regens Seminarium Kieleckiego,

2. Ks. Maciej Majerczak, dziekan Kolegiaty Kieleckiej, Wikariusz Apostolski i Administrator Diecezji Krakowsko-Kieleckiej, na część w Królestwie Polskim położoną, oraz

${ }^{31}$ Data pisma bkpa Majerczaka do prezesa Rady Głównej Laszczyńskiego, w którym biskup stwierdza wystarczalność funduszu SS. Mił. ${ }_{32}$ Tak quoad statum religiosum proprium, stricte et minus stricte dictum, jak i quoad statum religiosum improprium ac late acceptum. Por. We rnz F., Ius Decretalium, Tomus III, nr 593; U r ban us VIII, Const. "Romanus Pontifex" z 28. VIII. 1624.

${ }_{33}$ Nie w całości, tylko w punktach, dotyczących samej erekcji.

${ }_{34}$ Komisarz Biskupi, czyli Prokurator Domu SS. Mił., ustanowiony przez bkpa Majerczaka do zarządzania majątkiem szarytek. 
3. Erazm Różycki, dziedzic dóbr Żerniki i Zagórzyce, prezes Dyrekcji Szczególowej Towarzystwa Kredytowego Ziemskiego Gubernii Radomskiej w Kielcach i prezydujący w Radzie Zakładów Dobroczynnych Powiatu Kieleckiego, ze strony tejże Rady reskryptem $z$ dnia jedenastego czerwca tysiąc osiemset sześćdziesiątego roku $\mathrm{Nr}$ 337, do attentowania niniejszemu aktowi upoważniony, wszyscy w mieście powiatowym Kielcach Gubernii Radomskiej zamieszkali i zamieszkanie prawne co do aktu tego $\mathrm{w}$ tymże mieście obierający, mnie Rejentowi akt ten przyjmującemu, z osób i zdolności do działań urzędowych znani, do aktu tego prawomocni, niemniej w przytomności światków poniżej z imion, nazwisk $i$ miejsc wymienionych, zeznali akt osnowy następującej:

„W roku tysiąc osiemset pięćdziesiątym piątym (1855) przy ogłoszeniu w dniu (8) ósmym grudnia w mieście Kielcach dogmatu Niepokalanego Poczęcia Najświętszej Maryi Panny, Matki Bożej, bullą Jego Swiątobliwości Piusa Papieża IX, "Ineffabilis Deus" określonego, pragnąc tę uroczystość uwiecznić przez połączenie jej z miłosiernym uczynkiem, stawający do tego aktu wyżej wspomniany $X$. Maciej Majerczak, jako dziekan Kolegiaty Kieleckiej przyzwolił, aby jedna ze skarbon $w$ tejże Kolegiacie, w których zbieraja sie ofiary na potrzeby kościoła, odtąd przeznaczoną została na dobrowolną jałmużnę $w$ celu zaprowadzenia przy szpitalu św. Aleksandra w Kielcach Domu Sióstr Milosierdzia reguły św. Wincentego à Paulo, lub podobnychże sióstr albo braci innej jakiejkolwiek reguły, zawsze wyznania rzymsko-katolickiego. O tym zamiarze uprzedzoną została Rada Opiekuńcza Zakładów Dobroczynnych Powiatu Kieleckiego i takowy chętnie podzieliła.

W następstwie kilka osób pobożnych na tenże cel ofiarowało rozmaitej wysokości legaty tak, że suma zakładowa na uposażenie Domu Sióstr Milosierdzia przy szpitalu w Kielcach, wynosi rubli srebrem jedenaście tysięcy dwieście piędziesiąt, czyli zlotych polskich siedemdziesiąt pięc tysięcy. Procent od tej sumy ma slużyć na utrzymanie Sióstr Miłosierdzia.

Cały kapitał tak jako przez zapisodawców w pojedynczych sumach przeznaczony, oddany i darowany, zaś przez Joannę Schwartz, Wizytatorkę zaakceptowany, rzeczony X. Józef Gawroński, regens Seminarium Kieleckiego łącznie z stawajacym X Maciejem Majerczakiem, Administratorem i Wikariuszem Apostolskim Diecezji Krakowsko-Kieleckiej, imieniem tychże zapisodawców, przeznacza, oddaje, daruje i na wieczne czasy $z$ nich zaprowadza i uposaża Dom Sióstr Miłosierdzia w Kielcach, obsługa chorych przy szpitalu na teraz S-go Aleksandra trudnić się obowiązanych. Do tak uczynionej darowizny nikt prawa rościć nie może, stanowi ona prawną i bezporna własność tegoż Domu, do którego rzeczona Wizytatorka Joanna Schwartz, na mocy kontraktu miẹdzy nią, a obecnym temu aktowi Erazmem Różyckim, Prezydującym w Radzie Zakładów Dobroczynnych Powiatu Kieleckiego, na dniu jedenastym czerwca tysiąc osiemset sześdziesiatego roku spisanym, za siebie i za swoje nastepczynie jak na teraz, pieć Sióstr Miłosierdzia ze Zgromadzenia pod jej zarzadem w Prowincji obecnie Warszawska zwanej, ciagle utrzymywać zobowiązanie przyjęła i takowe własnoręcznie podpisała".

Gdyby dzisiejszy szpital S-go Aleksandra w Kielcach takie otrzymał przeznaczenie lub urządzenie, iż by Dom Sióstr Miłosierdzia 
istnieć przy nim na mocy reguły obowiązującej nie mógł, wówczas tenże X. Maciej Majerczak za siebie i następców swoich w duchu religii zobowiązanie przyjmuje przedsięwziąć silne i skuteczne starania, aby Dom rzeczony tu w Kielcach mógl inny szpital zalożyć $i$ przy nim nadal zbawiennemu swemu przeznaczeniu odpowiadać".

Tak zeznany akt, zaprowadzający Dom Sióstr Miłosierdzia przy szpitalu $w$ Kielcach, po zatwierdzeniu go przez Władze Rządowe ${ }^{35}$ wedle wymagalności praw krajowych, ma moc obowiązująca, wieczystą i co do litery na przyszłość ma być spelniony, - nad czym Rząd Krajowy, Władza Diecezjalna, oraz Zwierzchność szpitala miejscowego troskliwie czuwać raczą. W końcu stawający Erazm Różycki, prezydujący w Radzie Zakladów Dobroczynnych Powiatu Kieleckiego, w imieniu tejże Rady, przez nią reskryptem na początku powolanym upoważniony, oświadcza, że fundacje niniejszą Domu Sióstr Miłosierdzia dla obsługi chorych przy szpitalu Ś-go Aleksandra $w$ Kielcach akceptuje. - Po czym akt powyższy, odczytany wobec świadków Walentego Sojczyńskiego i Andrzeja Szajdakowskiego, obywateli krajowych, w mieście Kielcach zamieszkałych, niewylączalnych, i takowy przez stawających świadków, oraz mnie Rejenta podpisany zostal" 36 .

Nie pozostawia żadnych niedomówień jasność powyższego aktu erekcyjnego, zaprowadzającego Siostry Miłosierdzia w Kielcach. Niemniej nie pod każdym względem odpowiada on przepisom i duchowi prawa kościelnego, oraz praktyce Kościoła, który na założenie nowego Domu Zakonnego domaga się osobnego, formalnego i, o ile możności, pisemnego zezwolenia kompetentnych Władz Duchownych. Przepisy kościelne są tu wyraźne. Wprawdzie Zgromadzenie SS. Mił. nie zalicza się do zakonów, ani zgromadzeń zakonnych (nec ordo nec congregatio religiosa) i członkiniom jego nie przysługuje stricto sensu miano zakonnic (religiosae). Córki Miłosierdzia św. Wincentego à Paulo należą do stowarzyszenia niewiast, żyjących wspólnie na wzór zakonnic według swoich zatwierdzonych reguł ${ }^{37}$, oraz pod władza swych przełożonych. Z pięciu bowiem istotnych elementów, jakie musi mieć każdy zakon lub kongregacja zakonna, tzn:

35 Było niedopatrzeniem i błędem Władzy Duchownej, że nie posłarała się o zatwierdzenie aktu erekcji u Rządu. Z przykrością stwierdził to następca X Majerczaka bp Kuliński, gdy 26. VIII. 1870 roku Wladze Gubernii Kieleckiej zażadały oddania całego funduszu SS. Mił. dla sprawowania wyłącznego nad nim dozoru i gdy całe dzieło prawie niespostrzeżenie wymknęło sę z rąk Władzy Duchownej na rzecz. Władzy Świeckiej.

${ }^{36}$ Akta Domu Prowincjonalnego SS. Mił. w Warszawie.

${ }_{37}$ Pap. Innocenty X aprobowal zgromadzenie „Confrérie de la charitè" (Puellae Caritatis) w r. 1654; ostatecznie zaś regulę ich zatwierdzil pap. Klemens IX w r. 1668. 
a) praktykowanie ewangelicznej doskonałości, b) ślubów publicznych; c) własnych konstytucji; d) życia wspólnego; e) aprobaty Wladzy Kościelnej, brakuje im jednego elementu zasadniczego, mianowicie ślubów publicznych, przyjętych nomine Ecclesiae oraz a legitimo superiore ecclesiastico. I chociaż szarytki składają wszystkie trzy śluby ubóstwa, czystości i posłuszeństwa, śluby ich mają charakter prywatny, podczas gdy dla zakonów i dla zgromadzeń zakonnych wymagana jest koniecznie publica emissic trium votorum. Stąd Zgromadzenie Sióstr Miłosierdzia zwie się congregatio saecularis, lub pia congregatio, pia sodalitas, wreszcie institutum religiosum. Niemniej, ze względu na sposób życia, bardzo zbliżony do życia zakonnego, należy ono ,ad statum religiosum improprium atque late acceptum, in quo tota essentia status religiosi non habetur" 38. Z tego powodu w zakresie zarządu wewnętrznego rządzi się według reguł, oraz według przepisów prawa powszechnego, odnoszących się do zgromadzeń zakonnych congrua congruis referendo. W szczególności odnoszą się do stowarzyszeń tak jak do zgromadzeń zakonnych wszystkie zasady prawne, dotyczące erekcji i zniesienia domów i prowincji zakonnych. Sa stowarzyszenia, ich domy i prowincje zdolne do prawnego nabywania i posiadania dóbr materialnych, stosując $w$ administrowaniu majątków rygory prawa, jak w zgromadzeniach zakonnych; korzystaja $z$ wspólnych przywilejów duchownych, oraz tych, które stowarzyszeniom specjalnie udzielone zostały.

Podobnie więc jak congregatio religiosa, musiało zgromadzenie SS. Mił. uzyskać na założenie Domu zgodę Ordynariusza, w którego Diecezji nowy Dom miał powstać ${ }^{39}$. Liczne

${ }^{38}$ W e rnz F., dz. cyt. Tom III, nir 593.

${ }^{39} \mathrm{Na}$ erekcję nowego domu zakonnegō ścisłego (ordinis) konieczne było zezwolenie i Ordynariusza i Stolicy Apostolskiej (Decretalis Gregorii $\mathrm{X}$ a. 1273; Decretalis Bonificii VIII a. 1298; Decretalis Clementis $\mathrm{V}$ a 1311; Constitutio "Instaurandae" pap. Innocentis X 15. X. 1652; Benedict us XIV, De Synodo Dioecesana lib. IX. cap. I. n. 9; Praxis ac stylus Curiae Romanae; Constitutio „Romanos Pontifices" pap. Leonis XIII 8. V. 1881). Wprawdzie, gdy pap. Innocenty X Konstytucją „Instaurandae" z r. 1652 wydał pro Italia et insulis adiacentibus surowe zarządzenie, ,ne deinceps aliquis Regularium Ordinis Mendicantium vel non Mendicantium, Congregationis, Societatis et cuiusvis alterius Instituti, in aliqua sivitate, castro, villa, seu loco ad habitandum domos el loca quaecumquae de novo recipere vel fundare praesumat absque Sedis Apostolicae licentia speciali". - przyjęlo się powszechne obowiązujące postẹpowanie Kurii Rzymskiej, która rygor powyższej Konstytucji Papieskiej $z$ Italii $i$ wysp przyleglych rozszerzyła 
i wyraźne obowiązywały $\mathrm{w}$ tym względzie dekrety kościelne. $\mathrm{Za}$ podstawowe uważać należy orzeczenie Soboru Trydenckiego: „nec de cetero similia loca (scill. monasteria, seu domus tam virorum quam mulierum) erigantur sine Episcopi, in cuius Dioecesi erigenda sunt, licentia prius obtenta" (Sess. 25, cap. 3, De Regul.). To samo prawo, acz pośrednio, zawiera Konst. pap. Grzegorza XV. „Cum alias” z 17. VIII. 1622 roku, która pozwala na założenie Domu wtedy tylko, jeżeli Ordynariusz przekonał się, że nowy Dom będzie miał dostateczne utrzymanie i wystarczającą dla spelnienia wszystkich właściwych obowiązków liczbę zakonników czyli sióstr. Jeszcze silniej prerogatywy Ordynariusza w sprawie erekcji nowego Domu Zakonnego, tak w ścisłym jak i w szerszym znaczeniu, podkreśla Konst. pap. Urbana VIII „Romanus Pontifex” z 28. VIII. 1624 roku. Pod kara ekskomuniki, pozbawienia urzędów, niezdolności przyjęcia ich na przyszłość, zabronił Urban VIII „superioribus ordinum, congregationum, societatum, aliorumque institutorum" bez względu na nazwę" recipere, erigere, fundare, seu alias quomodolibet instituere nova monasteria, collegia, domus, conventus et alia loca regularia huiusmodi, nisi de expressa licentia Ordinariorum et servata in omnibus sanctorum canonum forma". $Z$ równą też siłą konieczność uzyskania zgody Ordynariusza na erekcję nowego Domu akcentują wszystkie Konstytucje papieskie, które ponadto domagają się licencji Stolicy Apostolskiej ${ }^{40}$.

Zatem pod rygorem nieważności erekcji konieczne było zezwolenie Ordynariusza i to wyraźne choćby tylko ustne.

w całej rozciągłości $w$ odniesieniu do każdego zgromadzenia na cały Kościół Katolicki. Wykładnikiem tej praktyki Stolicy Apostolskiej był pap. Benedykt XIV, który orzekł: „satis patet, nihil a Tridentina Synodo detractatum fuisse eiusdem Apostolicae Sedis auctoritati iam praecedenter stabilitae; sed illud dumtaxat statutum fuisse, ut, praeter eam, episcopalis quoque auctoritas et licentia in iisdem erectionibus interveniret. Communis hodie et in tribunalibus recepta opinio est, non licere regularibus, tam intra quam extra Italiam, nova monasteria sive collegia fundare sola Episcopi localis auctoritate, sed Apostolicae Sedis licentiam praetera necessariam esse" (De Synodo lib. IX, cap. I, n. 9). Papież Leon XIII Konstytucją „Romanos Pontifices” ostatecznie zaaprobował dla całego Kościoła obowiązująca moc Konstytucji „Instaurandae" i postępowanie w tym przedmiocie Kurii Rzymskiej. Mimo to, gdy chodziło o erekcję nowego Domu, należącego do Congregatio Religiosa, czy do Congregatio Saecularis, wymagana była w praktyce tylko wyraźna zgoda ordynariusza bez specjalnej i wyraźnej licenciji Stolicy Apostolskiej). (S. C. Episc. et Reg. 6. VI, 1860, 27. VII. 1860; Wernz F., Por. dz. cyt., Tom III, n. 619; Por. I c a rd H., Praelectiones Iuris Canonici, Tomus II, n. 449.

${ }_{40}$ Patrz przypisek 39. 
W praktyce jednak, mimo, że przepisy tego bezwzględnie nie wymagały, udzielał go biskup na piśmic w formie urzędowego dokumentu, który faktowi erekcji daje zawsze większą moc dowodową, zwłaszcza na przyszłość i potęguje ważność samego aktu.

Wiszystkie te przepisy prawne wypełnił ściśle bp Majerczak. Napewno zgodę swoją na założenie Domu SS. Mił. w Kielcach wyrazil nie tylko ustnie $i$ to niejednokrotnie, ale i na piśmie w oddzielnym, urzędowym akcie erekcji. Niestety akt ten zaginął. Trzeba więc innych dowodów na Ordinarii licentiam expressam. Dostarcza ich aż nadto urzędowa korespondenicja X. Majerczaka z Radą Główną Opiekuńczą, z Powiatowa Radą Opiekuńcza i z Marszałkiem Szlachty Gubernii Radomskiej, oraz — i to przede wszystkim - działalność biskupa w pomienionym przedmiocie. Dowody te są następujące:

1. Bp Majerczak jako pierwszy wystapil z projektem sprowadzenia SS. Mił. do szpitala św. Aleksandra w Kielcach i zamiar swój ogłosił publicznie i uroczyście $z$ ambony Kolegiaty Kieleckiej w dn. 8. XII. 1855 roku.

2. Zaapelował do ofiarności swych diecezjan, wysyłał pisma do duchowieństwa i ziemiaństwa, podajac zawsze jasno cel zbierania zapisów; sam też wyłącznie bez niczyjej czynnej współpracy zebrał cały fundusz na szarytki.

3. Zwracal się do Głównej i do Powiatowej Rady Opiekuńczej jako do Władz, sprawujących opiekę nad Instytucjami Dobroczynnymi w Królestwie Polskim, oraz do Marszałka Szlachty Gubernii Radomskiej jako do przedstawiciela obywatelstwa, $\mathrm{z}$ prośbą o moralne poparcie $\mathrm{w}$ powyższym celu, o pomoc w zbieraniu funduszów i wyjednania aprobaty Rządu.

4. Odniósł się wprost do Komisji Rządowej W.R. i O.P. o przyspieszenie zatwierdzenia funduszu na szarytki, oraz do najwyższych urzędników tej komisji, używając w pismach mocnych wyrażeń dla jasno sprecyzowanego dzieła.

5. W częstych pismach do S. Wizytatorki i do Dyrektora XX. Misjonarzy Prowincji Warszawskiej prosił o przysłanie szarytek dla opieki nad chorymi, zabiegał o podanie liczby zakonnic, potrzebnych dla szpitala, warunków ich utrzymania i pracy.

6. Razem z prezesem Powiatowej Rady Opiekuńczej Edwardem Różyckim i prokuratorem Domu SS. Mił. w Kielcach $\mathrm{X}$. Józefem Gawrońskim, stanął biskup Majerczak dn. 10. VIII. 1860 roku przed notariuszem Hilarym Kudlickim w Kiel- 
cach i własnoręcznie podpisał akt erekcii, konieczny dla Władz Cywilnych.

7. W powyższym akcie erekcji są dwie wyraźne wzmianki, stwierdzające zgodę Ordynariusza na założenie nowego Domu szarytek:

a) ,X. Majerczak przyzwolił, aby jedna ze skarbon $\mathrm{w}^{r}$ Kolegiacie przeznaczoną została na dobrowolną jałmużnę $w$ celu zaprowadzenia przy szpitalu Sw-go Aleksandra w Kielcach Domu Sióstr Miłosierdzia reguły św. Wincentego à Paulo, lub podobnychże sióstr albo braci innej jakiejkolwiek reguły" 41.

b) „Cały kapitał przez Joannę Schwartz Wizytatorke zaakceptowany, X. Józef Gawroński łącznie z stawającym X. Maciejem Majerczakiem, Administratorem i Wikariuszem Apostolskim Diecezji Krakowsko-Kieleckiej imieniem zapisodawców przeznacza, oddaje, daruje i na wieczne czasy z nich zaprowadza i upoisaża Dom Sióstr Miłosierdzia w Kielcach, obsługą chorych przy szpitalu na teraz S-go Aleksandra trudnić się oloowiązanych" 42.

8. Na wskazanie Laszczyńskiego, prezesa Rady Głównej, $z$ dn. 4. IV. 1860 roku, aby starania „o zakrzewienie w Kielcach Zgromadzenia Sióstr Miłosierdzia uzupełnić zezwoleniem J. W. Pana jako Zwierzchnika Diecezji" ${ }^{43}$, bkp Majerczak przesłal swą Ordinarii licentiam expressam na piśmie, co stwierdza w odezwach do Pow. Rady Opiek. 29. VIII. 1860 roku i do Rady Głównej 31. VIII. 1860 roku.

9. Osobiście brał X. Majerczak udział w ceremoniach przyjazdu SS. Mił. do Kielc i $w$ dniu 13. V. 1862 roku własnoręcznie podpisał protokół $\mathrm{z}$ wprowadzenia ich $\mathrm{w}$ urząd.

10. Dopełnieniem bezspornej zgody Ordynariusza w tym względzie jest:

a) aprobata legatów na szarytki przez Radę Administracyjną Królestwa $\mathrm{z}$ dn. 26. XI. 1861 roku.

b) upoważnienie Pow. Rady Opiek. przez Radę Główną do przyjęcia SS. Mił. z dn. 16. XII. 1861 roku.

Nie można ustalić dokładnej daty, kiedy biskup udzielił na piśmie zezwolenie na założenie nowego Domu Szarytek; niemniej pewnym jest, że uczynił to najpóźniej 10. VIII. 1860 roku, tj. w dniu, w którym przed rejentem podpisal akt erekcji razem z przedstawicielem Powiatowej Rady Opiekuńczej.

\footnotetext{
$41 \mathrm{Z}$ aktu erekcji, Akta Domu Prow. SS. Mit. w Warszawie.

42 Tamże.

43 Akta Kons. Tom I.
} 
Ten dzień należy uważać za termin formalnej erekcji Domu SS. Mił. przy szpitalu św. Aleksandra.

W kilkanaście dni po sporządzeniu aktu erekcji, 29. VIII. 1860 roku, przesłał X. Majerczak wszystkie cztery potrzebne dokumenty do Pow. Rady Opiek., a ta niezwłocznie do Rady Głównej. Stąd skierowane zostały kolejno przez Komisje Rządowe W. R. i O. P., Spraw Wewnętrznych, Sprawiedliwości do Rady Administracyjnej Królestwa. Rząd nie rozpatrywał kwestii, czy SS. Mił. są dla szpitala kieleckiego potrzebne, czy sprowadzenie ich jest pożądane, - decyzję tę zostawił Radzie Głównej Opiekuńczej; badał tylko, czy fundusze, przeznaczone na założenie nowego Domu, sa wystraczające, czy nie naruszają praw osób trzecich, czy zapisane są przez ofiarodawców w właściwej formie prawnej. Godząc się na legaty i zatwierdzając je, tym samym zatwierdzał sprowadzenje szarytek do szpitala.

Aprobata rządowa nie nadeszła tak wcześnie, jak się tego spodziewano. Przeszło rok musiał czekać na nią zniecierpliwiony już kip Majerczak. Dopiero w początkach grudnia 1861 roku otrzymała Rada Główna aprobowany dekret rządowy z dn. 26. XI. 1861 roku:

„W Imieniu Najjaśniejszego Aleksandra II-go Cesarza Wszech Rosji Króla Polskiego etc. etc. etc.

Rada Administracyjna Królestwa następujące zapisy... na utrzymanie Sióstr Miłosierdzia przy szpitalu św. Aleksandra w Kielcach uczynione zatwierdza.

Wykonanie niniejszego postanowienia Komisjom Rządowym Spraw Wewnętrznych oraz Sprawiedliwości, w czym do której należy, poleca.

Działo się w Warszawie dnia 26 listopada 1861 roku.

p. o. Namiestnika Jenerał Adiutant (podpisano) Luders. Radca Stanu Królestwa Sekretarz Stanu (podpisano) Karnicki".

Nie zwlekając już wcale, Rada Główna Opiekuńcza pismem z dnia 16. XII 1861 roku powiadomiła Pow. Radę Opiek. o przychylnej decyzji rządowej i upoważniła ją do formalnego przyjęcia SS. Miłosierdzia do szpitala św. Aleksandra. W ten sposób realizacja upragnionego zamiaru i usilnych starań $\mathrm{X}$. Majerczaka stała się możliwą. Należało tylko ustalić jeszcze i uzgodnić termin przybycia szarytek, czekających już od miesięcy na zaangażowanie. Ostatnią korespondencje przeprowadził w tym względzie Administrator Diecezji z Władzami Warszawskiej Prowincji Zgromadzenia. Przyjęły one bez zastrzeżeń wyznaczony przez Pow. Radę Opiekunczą dzień 13 maja 1862 roku jako datę objęcia nowej placówki w Kielcach. Doniosła o tym biskupowi S. Wizytatorka specjalnym pismem 
z początku maja 1862 roku, prosząc go równocześnie, aby w modlitwach swoich polecał Bogu ,tę nową osadę sług ubogich" 44 .

Było wolą biskupa, aby przyjąć SS. Mił. możliwie najuroczyściej. Naprzód więc, łącznie $\mathrm{z}$ prokuratorem szarytek $\mathrm{X}$. Józefem Gawrońskim i przewodniczącym Pow. Rady Opiek. Erazmem Różyckim, ułożył porządek wszelkich ceremonii tak w Kolegiacie jak i w szpitalu. Zaapelował do ludności miejskiej, do duchowieństwa i polskich organizacji zawodowych, poruszył całe miasto, nawołując do gromadnego udziału w tym tak ważnym zdarzeniu dla charytatywnego życia Kielc, pragnąc, aby u progu nowej placówki okazać SS. Mił. głębokie zaufanie i szacunek.

Uroczyste wprowadzenie w urząd nowych sióstr rozpoczęło się dnia 13. V. 1862 roku rano. O godz. 9 udały się nowoprzybyłe szarytki do Kolegiaty Kieleckiej, gdzie mszę św. śpiewaną odprawił Administrator Diecezji X. Maciej Majerczak. W czasie mszy św. siostry przyjęły komunię św. Było ich sześć: S. Wizytatorka Prowincji Warszawskiej Joanna Schwartz, która $z$ urzędu swego nowym pracowniczkom przewodniczyła, oraz pięć innych sióstr, przeznaczonych do opieki nad chorymi. Po mszy św. uformowała się procesja z miejscowym duchowieństwem, cechami rzemieślniczymi, poprzedzonymi chorągwiami i z licznie przybyłą ludnoścą. Pochód procesjonalny prowadził od Kolegiaty do szpitala św. Aleksandra. W czasie procesji śpiewano litanię do Wszystkich Swiętych. Tuż za celebransem bkpem Majerczakiem postępowała S. Wizytatorka, następnie pozostałe siostry i członkowie Pow. Rady Opiek. Po przybyciu do szpitala, wpierw bkp Majerczak poświęcił gmach szpitalny i mieszkanie sióstr, po czym nastąpił akt istotny: Erazm Różycki, jako przewodniczący Rady Opiekuńczej Zakładów Dobroczynnych Powiatu Kieleckiego, wręczył publicznie klucze szpitala S. Przełożonej Wiktorii Postkowskiej, powierzając w ten sposób szpital i chorych opiece Sióstr Miłosierdzia.

$Z$ uroczystości tej sporządzono protokół, podpisany przez X. Majerczaka, X. Józefa Gawrońskiego, Erazma Różyckiego i Joannę Schwartz.

Pierwszy Dom szarytek w Kielcach liczył 5 sióstr. Liczba ta była wystarczająca dla podołania wszystkim obowiązkom w szpitalu, oraz zgodna $\mathrm{z}$ obowiązującymi przepisami praw-

\footnotetext{
44 Akta Kons. Tom I, pismo S. Wizytatorki do biskupa z maja 1862 roku.

16 - Prawo Kanoniczne
} 
nymi aczkolwiek z przepisami więcej lagodnymi. Ze względu na celowość życia zakonnego, możność wspólnego zachowania reguły i wspólnego spełnienia wszystkich prac zakonowi właściwych, od wieków wydał Kościół zarządzenia, dotyczące liczby braci, zakonników i sióstr w każdym nowo założonym Domu. Według pierwszych dekretów papieskich w nowym Domu winno żyć wspólnie 12 osób. Wymaganie takie stawiał pap. Grzegorz XV w Konst. „Cum alias” z dn. 17. VIII. 1622 roku: ,in domibus cuiuslibet ordinis, societatis et instituti religiosorum saltem duodecim fratres aut monachi aut religiosi inhabitare”. Potwierdzeniem obowiązującej mocy Konst. „Cum alias", były dalsze późniejsze $w$ tym przedmiocie zarządzenia najwyższych Władz Kościelnych: Konst. pap. Urbana VIII „Romanus Pontifex" z 28. VIII. 1624 roku; Dekret S. C. Ep. et Reg. z dn. 21. VI. 1625 roku, wydany z nakazu pap. Urbana VIII. Bulla pap. Innocentego XII "Nuper" z 23. XII. 1697 roku. Z ducha powyższych zarządzeń wynikało ${ }^{45}$, że Dom erygowany, jeżeli nie zaraz, to $\mathrm{w}$ krótkim czasie winien $\mathrm{z}$ moralną pewnością osiągnąć liczbę 12 członków. Niemniej w praktyce tylko dla mniszek, składających śluby uroczyste i żyjących pod klauzurą papieska, wymagana była bezwzględnie liczba $12{ }^{46}$, dla innych Domów przyjęła się w postępowaniu Kurii Rzymskiej wystarczająca przy erekcji liczba 6 członków ${ }^{47}$. A nawet, gdy chodziło o Congregatio Saecularis, uwzględniając starą zasadę "tres faciunt collegium", wydała Kongregacja Episc et Regul. dn. 26. VI. 1870 roku zarzadzenie, w myśl którego już dawniej postępowano, ,ut in Domibus Pii Instituti saltem tres sorores simul commorentur, usquedum numerus augeri nequeat" ${ }^{48}$. Niemniej było życzeniem Władz Kościelnych, aby i w tych Domach żyło wspólnie 6 sióstr.

Zatem liczba 5 sióstr w Domu Kieleckim pokrywała się z obowiązującymi przepisami Kościoła. Oto nazwiska pierwszych szarytek: 1. Wiktoria Postkowska, przełożona, lat 46, po ślubach, 2. Rozalia Gregorczyk, lat 26, po ślubach, 3. Julia Swwiderska, lat 26, bez ślubów, 4. Karolina Chmielińska, lat 21, bez ślubów, 5. Antonina Wędrychowska, brak innych danych w źródłach.

45 Por. F a $\mathrm{n}$ a $\mathrm{n}$ i L., De iure religiosorum, nr 21. C. IV.

48 Por. S. Congr. Ep. et Reg. 6. VI. 1605; 5. V. 1690; 27. IV. 1855.

47 Stwierdza to w części historycznej Konst. pap. Leon. XIII „Romanos Pontifices" z dn. 8. V. 1881 roku.

${ }_{48}$ Dekretem $z$ dn. 25. IV. 1896 roku wymagala już S. C. Ep. et Reg. liczby 4. sióstr dla Domu Pii Instituti. 


\section{Utrzymanie domu, legaty}

W każdym dziele, służącym dobru ogólnemu, nieodzownym i zasadniczym jest kapitał bez względu na formę, w jakiej występuje. Zasada ta najściślej odnosi się do Instytucji Charytatywnych, mających czynną pomocą służyć bliźnim.

Od samego początku realizacji zamiaru sprowadzenia SS. Mił. do szpitala kieleckiego, brak jakichkolwiek funduszów był przeszkodą największą i trudną do usunięcia. Wprost nie łatwym było znalezienie właściwego sposobu zbierania funduszu zakładowego. Chociaż różne osobistości tak z życia prywatnego jak i publicznego samą myśl oddania szpitala szarytkom gorąco popierały i $\mathrm{w}$ miarę możności o to zabiegały, nic jednak na ten cel nie przeznaczyły i o nic się nie postarały. Jak często w życiu bywa, tak i w tym wypadku, poza dobrymi chęciami, pięknymi radami, poza, rzec by można, życzliwością na odległość, nikt z konkretną pomocą nie pospieszył. Także Rada Opiekuńcza Zakładów Dobroczynnych tak Powiatowa jak i Główna, z urzędu swego władzę nad szpitalem sprawujące i na mocy tego samego urzędu do gromadzenia funduszów powołane i obowiązane, okazały wprawdzie dużo zainteresowania, udzieliły $w$ całej pelni poparcia i pomocy, ale tylko moralnej. Same ze swych pustych kas ani jednego rubla nie ofiarowały, oraz nie wyjednały żadnej nawet najmniejszej subwencji czy to od Rządu, czy to od innych Instytucji. To samo stanowisko co Rady Opiekuńcze, zajął również Marszałek Szlachty Gubernii Radomskiej E. Niemojewski. Cały więc ciężar zebrania funduszów na szarytki spadł na inicjatora projektu, Administratora Diecezji Krakowsko-Kieleckiej, X. Macieja Majerczaka. Niemało to sprawiło mu kłopotu. Przez cztery lata i dwa miesiące zabiegom tym dużo poświęcal czasu, popierając je zawsze osobistym wpływem $\dot{i}$ akcentowaną wzniosłością celu. Gdy po dokładnym obliczeniu kosztów utrzymania pięciu sióstr doszedł do wniosku, że kwota zakładowa na założenie nowego Domu i opłacenie go $z$ procentów musi wynosić co najmniej 11250 rubli, czyli 75000 złotych polskich, prawdziwie $\mathrm{z}$ uporem potrzebny fundusz zaczął zbierać. Aby dzieło nie utknęło, działał szyblo i energicznie; nie było bowiem żadnych złudzeń, że odpowiedni kapitał zakładowy jest koniecznym warunkiem sprowadzenia SS. Mił. Na straży tego „,conditio sine qua non" stały Władze Rządowe i Prawo Kościelne.

Rząd Rosyjski na mocy Ustawy Szpiłalnej z dn. 2. III. 1842 roku zastrzegł sobie wyłączne prawo zatwierdzenia legatów, 
służących utrzymaniu nowego Domu Zakonnego w szpitalach, oraz decyzji, czy fundusze, przedstawione do aprobaty przez Radę Główną Opiekuńczą, są na ten cel wystarczające. Bez tego rodzaju zgody Rządu, Rady Opiekuńcze nie mogły oddać chorych w szpitalu pod opiekę jakiegokolwiek Zgromadzenia Zakonnego.

Podobnie rozsądzało sprawę prawo kościelne. Zakazywało ono wyraźnie erygowania Domu Zakonnego, jeżeli nie było należytych funduszów, na utrzymanie, lub, jeżeli funduszów tych rozsądnie przewidzieć nie było można. Surowe zarządzenie wydał w tym przedmiocie pap. Grzegorz XV w Const. „Cum alias" z 17. VIII. 1622 roku. Po tej samej linii w odniesieniu do ,aliorum institutorum, quovis nomine appellentur", szła Konstytucja pap. Urbana VIII „Romanus Pontifex” z 28. VIII. 1624 roku, oraz Dekret S. C. Episc. et Regul. z dn. 21. VI. 1625 roku.

W wyszukaniu źródeł dochodu i podstawy utrzymania dawało prawo kościelne swobodę inicjatorom zamiaru i wykonawcom. Utrzymanie Domu zapewnić mogły własne dochody $\mathrm{z}$ pracy $\mathrm{w}$ szpitalach, $\mathrm{w}$ szkolnictwie, $\mathrm{w}$ duszpasterstwie, na misjach itd., jałmużny zwyczajne, wreszcie jakiekolwiek inne godziwie uzyskane fundusze. Sąd o tym, czy założenie nowego Domu Zakonnego było celowe, czy nie godziło $\mathrm{w}$ inny istnjejący już w innej miejscowości Dom Zakonny ${ }^{49}$, czy nie byłoby ciężarem dla miejscowej ludności, oraz, czy nowy Dom $\mathrm{Za-}$ konny miał zapewnione należyte utrzymanie i przez to nie

\footnotetext{
$49 \mathrm{~W}$ stosunku do nowego Domu męskiego, zwłaszcza męskiego zakonu ścisłego, obowiązywały ponadto bezwzględnie przepisy, mówiące, że Ordynariusz nie inaczej mógł udzielić zezwolenia na erekcję, „quam vocatis et auditis aliorum in iisdem civitatibus et locis existentium conventuum prioribus et procuratoribus et aliis interesse habentibus; et causa cognita constiterit, in eisdem civitatibus et locis novos huiusmodi erigendos conventus sine aliorum detrimento commode sustentari posse. Vel alias Ordinariis locorum constiterit id fieri posse absque praeiudicio religiosorum in monasteriis, seu Domibus ante erectis degentium" (Clemens VIII, Const. „Quoniam ad institutum” 23. VII. 1603). Erekcja nowego Domu nie mogła pociągnąc szkody klasztorów już istniejących $w$ przestrzeni ,in aliis per quattuor millia passuum circumvicinis locis" (Gregorius XV, Const. „Cum alias” 17. VIII. 1622); Było to tak zwane privilegium cannarum.

Przy erekcji zaś nowego Domu żeńskiego, nawet należącego do zakonu ścisłego, zgoda sąsiednich konwentów według starodawnej praktyki S. C. Ep. et Reg. nie była wymagana; wystarczało o tym stwierdzenie Ordynariusza, że nowy Dom żeński miał zapewnione stałe utrzymanie dla określonej prawem ilości zakonnic. Por. M o c ch eg i a i P., Iurisprudentia Ecclesiastica, Tomus I n. 257.
} 
był narażony na niepewność istnienia, należał do Ordynariusza miejsca, w którym Dom miał powstać ${ }^{50}$.

W tym wypadku osobą, zbierającą fundusze, jest sam inicjator projektu bp Majerczak, Administrator Diecezji. Jemu też najwięcej na tym zależało, aby rozpoczęte dzieło doprowadzić do końca, oraz zapewnić mu pewną i trwałą przyszłość przez zebranie możliwie najwięcej ofiar i legatów. Tej okoliczności w pierwszym rzędzie należy przypisać, że potrzebne kapitały na utrzymanie szarytek stosunkowo szybko zebrano.

Mimo skrupulatnego rozważania źródeł funduszów i licznych w tym względzie prób, jedno tylko źródło okazało się realne i niezawodne, a tym była ofiarność publiczna. Wyrażała się ona w dwojaki sposób: przez skarbonę kościelną i przez legaty. Do niej uciekł się Administrator Diecezji tego samego dnia, kiedy swój zamiar wprowadzenia szarytek ogłosił; już bowiem 8. VIII. 1855 roku przeznaczył na ten cel jedną ze skarbon w Kolegiacie Kieleckiej, do których wpływały ofiary na potrzeby kościelne. Często kapłani z ambony przypominali wiernym istnienie tej skarbony, która była zaczątkiem funduszu SS. Mił. i nadspodziewanie obficie fundusz ten powiększała. Przez niecałe półtora roku do 1. IV. 1857 roku przyniosła ona r. 564 kop. 50, a do 13. I. 1859 roku 1050 rubli, czyli 7000 złotych polskich. Przeciętnie wpływało do skarbony rocznie 300 rub., czyli $2000 \mathrm{złp}$.

Drugą zarazem najważniejszą formą ofiarności publicznej były legaty, złożone przez biskupa, kapłanów, ziemian i pobożnych diecezjan. Jako pierwszy - aby przykładem swym pociągnąc innych - uczynił to bp Majerczak. Gdy 7. VI. 1857 roku prosił, zresztą bezskutecznie, Marszałka Szlachty o ofiarę i uproszenie Rządu o subwencję, w tymże piśmie stwierdza, że już dawniej zadeklarował na szarytki raz 600 rubli, następnie 400 rubli, a obecnie jeszcze rubli 500, czyli razem 1500 rubli $(10000 \mathrm{złp})$. Powołując się chętnie na własną ofiarność i wyczerpanie swych funduszów, kieruje odręczne pisma przede wszystkim do swych zamożnych proboszczów, następnie do okolicznych dziedziców. Gorące apele w szlachetnej intencji znajdują poparcie zwłaszcza u proboszczów. W odpowiedziach pełnych oddania, ofiarują poważne sumy. „Pelne to zacności Duchowieństwo tutejszej Diecezji" ${ }^{51}$ w ciągu niecałych pięciu

${ }^{50}$ Por. Decretum Tridentinum, Sess. XXV, cap. 3. De Regul.; Const. Gregorii XV „Cum alias" 17. VIII. 1622; Const. Urbani VIII ,Romanus Pontifex" 28. VIII. 1624.

${ }^{51}$ Slowa bkpa Majerczaka, Akta Kons. Tom I. 
lat zapisało ze swego prywatnego majątku i oszczędności większą część całego potrzebnego funduszu na SS. Mił. Ósmego marca 1860 roku wystarczająca kwota zakładowa wynosiła 11250 rub., czyli 75000 złp. Ofiary te złożyli wobec notariusza w urzędowej formie:

1. Władysław Ruảnicki, dziedzic dóbr Kobylany w pow. opatowskim Gubernii Radomskiej, dnia 5. VI. 1859 roku, R. 3000, czyli $20000 \mathrm{zlp}$.

2. X. Florian Sławęncki, proboszcz parafii Książ Mały w Diecezji Kielecko-Krakowskej, dnia 17. VI. 1859 roku, R. 750, czyli 5000 zlp. 3. X. Eukasz Tarnawski, proboszcz parafii Kozłów w Diecezji Kielecko-Krakowskiej, dnia 9. XI. 1859 roku, R. 3000, czyli $20000 \mathrm{zlp.}$ 4. X. Maciej Majerczak, Administrator i Wikariusz Apostolski Diecezji Kielecko-Krakowskiej, dnia 11. VI. 1860 roku, R. 1500, czyli $10000 \mathrm{zlp}$.

5. X. Józef Królikiewicz, kanonik honorowy kaliski, proboszcz parafii Irządze w Diecezji Kielecko-Krakowskiej, dnia 26. VI. 1860 roku, R. 450, czyli 3000 zlp.

6. X. Bartłomiej Jarzębski, kanonik honorowy sandomierski, emerytowany b. proboszcz w Szkalbmierzu w Diecezji Kielecko-Krakowskiej, dnia 10. VII. 1860 roku, R. 1500, czyli 10000 złp.

7. X. Maciej Majerczak, $z$ ofiar składanych do skarbony w Kolegiacie Kieleckej, $z$ darów osób pobożnych, z procentów dotychczasowych tj. do dn. 29. I. 1859 roku, dnia 11. VI. 1860 roku, R. 1050, czyli $7000 \mathrm{zlp}$. - Razem R. 11250 , czyli $75000 \mathrm{zlp.}$

Prowizoryczne obliczenie wykazało, że procent pięć od stu od zakładowej sumy R. 11250, wystarcza na pokrycie kosztów utrzymania pięciu sióstr. Na koszta te poza mieszkaniem, opałem i usługą, które daje szpital, składać się mają:

Żywność dla 5 sióstr przez 365 dni, razem dni 1825 po 20 kopiejek dziennie, R. 365. Habity i bielizna dla 5 sióstr po R. 30. na osobę, R. 150. Myđło do prania bielizny, licząc po 10. funtów na osobę, razem funtów 50 pó 12 kopiejek, R. 6. Razem R. 521.

Wprawdzie procent od funduszu zakładowego wynosił rocznie tylko R. 500 (5\% od R. 11250), niemniej stale ofiary do skarbony i spodziewane dalsze legaty, winny wyrównać niedobór R. 21; ostatecznie zaś można by bez braków w wyżywieniu zmniejszyć o kilka kopiejek codzienną stawkę tym więcej, że jest ona wysoka.

Najtrudniejsza więc od samego początku kwestia utrzymania szarytek, jest już rzeczą pewną.

Wszystkie legaty, zanim mogły służyć właściwemu celowi, musiały wpierw otrzymać zatwierdzenie Rządu, a tym samym mogły stanowić prawną podstawę utrzymania SS. Mił. Zastrzegła sobie Rada Główna Opiekuńcza, że nie wcześniej prześle wykaz funduszów do aprobaty władz Rządowych, aż nie otrzyma od bpa Majerczaka urzędowo i przez notariusza sporządzonych aktów akceptacji wszystkich zapisów, doku- 
mentów, stwierdzających hipoteczne zagwarantowanie ich na nieruchomościach, oraz aktu erekcji, sporządzonego wobec notariusza i podpisanego przez władzę Duchowną i przez Powiatową Radę Opiekuńczą. Już wcześniej pomyślał o tym X. Majerczak; leżało bowiem w interesie Instytucji SS. Mił. i samego inicjatora, aby zaofiarowane kwoty były zabezpieczone w sposób pewny i, aby jak najwcześniej przynosiły dochód $\mathrm{z}$ procentu. W tym celu, ustanowiony prokurator Domu SS. Mił., zarządzający ich majątkiem, X. Józef Gawroński, z polecenia bpa Majerczaka ulokował całą sumę zakładową hipotecznie na dobrach ziemskich $\mathrm{i}$ to $\mathrm{w}$ formie notarialnej ${ }^{\circ 2}$.

Sporządzenie aktu akceptacji funduszu zakładowego spowodowało różnicę zdań między bpem Majerczakiem i Radą Główną Opiek. Chodziło tu o sprawę tak ważną, jak o ustalenie prawnego wlaściciela i zarządzającego całym kapitałem szarytek. Rada Główna, powołując się na swe prawa wyłącznego rządzenia szpitalem, czyniła nacisk, aby akceptacji dokonała Pow. Rada Opiek. Na umotywowanie swego żądania dostarczała słusznych częściowo dowodów, twierdząc, że fundusze na szarytki, tym więcej fundusze wieczyste, dysponowane mogą być przez tę tylko Władzę, która zarządza całym Zakładem Dobroczynnym. Inaczej pracownicy szpitala zależni by byli w sprawach finansowych od innej Władzy zewnętrznej spoza szpitala. Na taką koncepcję w żadnym wypadku nie chciał biskup się zgodzić. I słusznie; oddanie bowiem kapitału zakładowego SS. Mił. w ręce Pow. Rady Opiek. przekreśliłoby wszelką $w$ tym względzie prawną ingerencję Władzy Duchownej. Doszłoby siłą rzeczy do złączenia funduszu szarytek $z$ ogólnymi funduszami szpitala, a wtedy Władze Rządowe mogłyby z czasem zadysponować wszystkimi funduszami szpitala $\mathrm{w}$ zależności od własnych decyzji. W praktyce równało to by się całkowitemu odsunięciu od wpływu tego czynnika, który sam bez niczyjej pomocy i współpracy cały fundusz zebrał $i$ cały kapitał wymknąłby się Kościołowi z rąk. Pewność utrzymania sióstr byłaby $w$ takich warunkach wątpliwa. Dokładał więc X. Majerczak wszelkich starań, aby kwota zakładowa szarytek nie była włączona do funduszów szpitala, lecz, aby stanowiła wieczystą i wyłączną własność Kościoła, w tym wypadku Zgromadzenia Sióstr Miłosierdzia, a zarządzana była tylko przez Władzę Duchowną. Powołanie się na przykład in-

52 Formalności tej domagał się bkp Majerczak przy udzielaniu pożyczki, oraz Rada Gł. Opiek. przed przedłożeniem funduszu zakładowego do aprobaty Rządu. 
nych szpitali, gdzie kapitały na SS. Mił. zapisane, nie podpadały pod zarząd Rad Opiekuńczych, skłoniło Radę Główną do ustępstwa tym więcej, że Pow. Rada Opiek. poparła z zasady stanowisko bpa, oświadczając, że „Rady Opiekuńcze zawiadują funduszami Zakładów Dobroczynnych, ale nie Zgromadzeń Religijnych" 53. Podmiotem zatem akceptacji było Zgromadzenie SS. Mił. jako właściciel funduszu zakładowego. Dokonała jej notarialnie $w$ imieniu Zgromadzenia S. Wizytatorka Prowincji Warszawskiej, Joanna Szwartz.

Kilka dni później, 10. VIII. 1860 roku, stanęli przed rejentem Hilarym Kudlickim w Kielcach X. bp Maciej Majerczak, X. Józef Gawroński i prezes Pow. Rady Opiek. Erazm Różycki, aby sporządzić urzędowy akt erekcji. Akt ten wraz $z$ umową, $z$ wykazem wszystkich legatów i ich akceptacji, został zaraz przesłany za pośrednictwem Rad Opiekuńczych do Komisji Rządowej W. R. i O. P. z prośbą o zatwierdzenie.

Za zgodą obu Władz, sprawujących nadzór nad SS. Mił. w szpitalu kieleckim, tj. Kurii Diecezjalnej i Porwiatowej Rady Opiekuńczej, sformułowano $w$ akcie erekcji zasadnicze stwierdzenie, dotyczące kapitału zakładowego, sposobu zarządzania nim, wyszczególniono dokładnie cel tych kapitałów, oraz warunki utrzymania szarytek.

I tak cała suma R. 11250, czyli 75000 złp., stanowiąca wieczysty fundusz zakładowy, przez zapisodawców ofiarowana i od.nich już podjęta, znajdowała się w dn. 10. VIII. 1860 roku w depozycie Seminarium Duchownego w Kielcach. Poświadczają to wobec notariusza stawający do aktu erekcji bp Majerczak, oraz regens Sem. Duch. i prokurator szarytek X. Józef Gawroński, którzy odbiór wszystkich zapisów kwitują. Następnie cały kapitał zakładowy, już przedtem przez S. Wizytatorkę formalnie wobec rejenta zaakceptowany, bp Majerczak w imieniu zapisodawców przeznacza, oddaje, daruje i na wieczne czasy $z$ nich zaprowadza i uposaża Dom Sióstr Miłosierdzia w Kielcach" 54. Darowizna, o której akt erekcji mówi, że do niej ,nikt prawa rościć nie może ${ }^{55}$, że „stanowi ona prawną i bezsporną własność Domu Sióstr Miłosierdzia w Kielcach" 56, była zatem całkowita i jasno odnosiła się do szarytek jako do prawnego właściciela. Nikomu nie wolno było użyć funduszu na szarytki dla jakiekogolwick innego celu, w szcze-

${ }^{53} \mathrm{Z}$ pisma prezesa Pow. Rady Opiek. Erazma Różyckiego do bkpa Majerczaka z czerwca 1860 roku. Akta Kons. Tom I.

${ }_{54}$ Akta Domu Prow. $w$ Warszawie, akt erekcji $\S \mathrm{I}$.

55 Tamże.

${ }_{56}$ Tamże. 
gólności zaś dla powiększenia uposażenia szpitala, lub połączenie go $\mathrm{z}$ ogólnymi funduszami szpitalnymi (akt erekcyjny § II).

Gdyby przybycie SS. Mił. do Kielc dla jakich ważnych względów opóźniło się, cały kapitał zakładowy miał przejść na własność SS. Mił. w Królestwie Polskim i razem z wrastającymi procentami służyć ich potrzebom; niemniej $\mathrm{w}$ czasie odpowiednim, choćby po kilkunastu latach, gdyby pielęgnowanie chorych przez SS. Mił. w Kielcach nawet w innym nowym szpitalu było możliwe, fundusz cały miał znów stanowić podstawę utrzymania dla szarytek kieleckich (akt erekcyjny $\S$ IV). Zawrsze nazwa kapitału ma się cidnosić do „Instytucji Domu Sióstr Miłasierdzia" nawet wtenczas, gdyby szpital św. Aleksandra po pewnym czasie przestał istnieć. I w tym wypadku nie można by włączyć funduszu zakładowego do funduszów zlikwidowanego szpitala, lecz należałoby przeznaczyć go Siostrom Mił. na utrzymanie chorych według uznania zakonnic. Obowiązek czuwania i wykonania tego postanowienia, spoczywa na. Władzy Diecezjalnej (akt erekcyjny §V).

Także w razie likwidacji Zgromadzenia SS. Mił. w Królestwie Polskim, całe uposażenie szarytek w Kielcach przechodzi na własność innej „Instytucji Religijnej” wyznania rzymsko-katolickiego, rozwijającej działalność w Zakładach dla chorych lub ubogich. Instytucja ta pod względem uposażenia weszłaby we wszystkie prawa Domu SS. Mił. w Kielcach (akt erekcyjny § VI). Gdyby jednak w miejsce SS. Mił. żadnej „Instytucji Religijnej" zaprowadzić nie można, wtenczas kwota R. 3000. z legatu Władysława Rudnickiego, zgodnie z myślą darującego, wypłacona zostanie szarytkom, wszelkie zaś inne legaty przejdą na fundusz wzniesienia lub uposażenia Domu Księży Emerytów dla świeckiego duchowieństwa Diecezji Kieleckiej (akt erekcyjny § VII). Decyzję taką może Władza Diecezjalna wtedy powziąć, jeżeli co najmniej po 10 latach, po wszelkich daremnych staraniach, w żaden sposób nie będzie mogła przeznaczyć odnośnego kapitału na zakład dla chorych lub ubogich. „Zostawia się to chrześcijańskiemu sumieniu i zacności serca Dostojnych Naczelników Duchownych, pod których zarząd Kielce podpadać moga" (akt erekcyjny § VIII).

Aby uniknąć ewentualnej straty, spowodowanej obniżeniem wartości pieniądza, cały kapitał zakładowy winien zawsze być umieszczony na dobrach ziemskich, lub na nieruchomościach miejskich, nie zaś w bankach (akt erekcyjny §III). Przy tym kandydaci, starający się o pożyczkę poddani będą skrupulatnemu przeglądowi ich stanu materialnego. 
Ponadto w każdym wypadku udzielenia pożyczki, Władza Duchowna zasięgać będzie informacji poważnych miejscowych czynników, aby się upewnić, czy ubiegający się o pożyczkę jest osobą ze wszech miar uczciwa i zgodną, daleką od powodowania trudności i sporów (akt erekcyjny § XIII).

Wypożyczanie kapitałów i lokowanie ich na dobrach oraz na nieruchomościach, przeprowadzać będzie Władza Duchowna po uprzednim uzyskaniu na to zgody Pow. Rady Opiek. jako Władzy Zwierzchnej szpitala i przełożonej Domu SS. Mił. (akt erekcyjny $\S \mathrm{XIV}$ ).

Zmiana warunków przy udzielaniu pożyczki możliwa jest tylko wtenczas, jeśli nawet $\mathrm{w}$ najmniejszym stopniu nie spowoduje umniejszenia kwoty zakładowej i jej bezpieczeństwa, oraz, jeżeli nie obniży należnych procentów (akt erekcyjny $\S \mathrm{XIII})$.

Wszelkie nowe legaty, jakie wpływać będą na szarytki, pozostaną pod zarządem Władzy Diecezjalnej z tymi samymi warunkami, jakie odnoszą się do funduszu zakładowego. Gdyby nowe zapisy tak wzrosły, że przekroczyłyby kwotę, przewidzianą na utrzymanie i wszystkie właściwe urządzenia Domu miejscowego, zastrzega się dla biskupa kieleckiego prawo przekazania części nowych funduszów na cele sierót w Ochronce, lub starców w Schronisku św. Tróicy w Kielcach ${ }^{57}$ z zachowaniem wszakże nazwy „Instytucji Domu SS. Mił." Możliwe to byłoby wtenczas, gdyby liczba sióstr w szpitalu nie wymagała powiększenia (akt erekcyjny §IX).

Oszczędności z obrotu kapitałem szarytek, doliczane będą po zaspokojeniu wszystkich ich potrzeb do funduszu ogólnego (akt erekcyjny $\S$ XVIII).

Stosownie do umowy $\mathrm{z}$ dn. 11 . VI. 1860 roku na utrzymanie każdej siostry przeznacza się rocznie R. 90, czyli 600 złp; na utensylia zaś, na pranie i światło, dodaje się rocznie $R .10$, czyli 66,20 złp. Razem więc pensja roczna jednej siostry wynosiła R. 100 , czyli 666,20 złp. (akt erekcyjny $\S \mathrm{XV}$ ). Była to suma wystarczająca na opędzenie średnich warunków życia, duchcwi zakonnemu właściwych. Przełożona Domu nie rozlicza sie ani przed Pow. Radą Opiek., ani przed prokuratorem z kwoty R. 500, otrzymywanej na roczne utrzymanie pięciu sióstr (umowa art. I). Pensja sióstr może ulec podwyższeniu, jeżeli pozwoli na to fundusz ogólny (akt erekcyjny $\S \mathrm{XV}$ ).

${ }^{57}$ Biskup Majerczak nosił się z zamiarem urządzenia Ochrony dla dzieci i Schroniska dla starców, oraz powierzenia tych Zakładów opiece i kierownictwu SS. Mił. 
Koszta pierwszej podróży sióstr do szpitala i transportu ich rzeczy, wydatki na sprowadzenie nowej siostry w miejsce zmarłe j, ponoszone będą $z$ funduszu ogólnego na szarytki (umowa art. 9).W razie powiększenia szpitala i konieczności sprowadzenia więcej sióstr nad liczbę pięć, nowe siostry tak co do pensji rocznej, jak i co do poniesienia kosztów przejazdu, przyjęte będą na warunkach, obowiązujących na początku (umowa art. 9). Przy zwykłych podróżach sióstr, koszta podróży ponosić będzie ta Władza, która zmiany zażąda. Zatem i Pow. Rada Opiek. na ten cel musi w razie potrzeby znaleźć środki z kasy szpitalnej; przełożonej szarytek zaś wypłacać będzie prokurator $\mathrm{z}$ funduszu ogólnego rocznie kwotę R. 30 (200 złp.), wystarczającą na wszelkie podróże sióstr, odbywane $\mathrm{z}$ woli Władz Zgromadzenia.

Przed przybyciem do Kielc otrzyma przełożona $z$ funduszu ogólnego na każdą siostrę R. 100. (666,20 złp.), czyli razem na pięć sióstr R. 500 (3333,10 złp.), jako jednorazowe honorarium na pierwsze zagospodarowanie na miejscu. $Z$ sumy tej poniosą siostry koszta przejazdu z Warszawy do Kielc. Honorarium to wypłacać się będzie na przyszłość $\mathrm{w}$ tej samej wysokości tylko w wypadku powiększenia liczby sióstr, nie zaś w razie zmiany sióstr (umowa art. 15).

Całym funduszem zakładowym, stanowiącym wyłączną własność SS. Mił., zarządzać będzie Duchowna Władza Diecezjalna, która w ten sposób pragnie oszczędzić szarytkom zabiegów natury finansowej i nie odrywać ich od pracy przy chorych. $\mathrm{Z}$ upoważnienia $\mathrm{i} \mathrm{w}$ imieniu biskupa bezpośredni zarząd kapitałów sprawować będzie regens Seminarium Duchownego w Kielcach, lub regens Sem. Duch. tej Diecezji, do której Kielce mogą należeć. Będzie on nosił tytuł komisarza biskupiego, czyli prokuratora Domu SS. Mił. Do obowiązków jego należy umieszczanie legatów na dobrach ziemskich i budynkach miejskich, przenoszenie kapitałów na inne nieruchomości, pobieranie procentów i wypłacanie ich siostrom, doliczanie oszczędności do funduszu ogólnego i zapewnienie $\mathrm{z}$ nich procentów (akt erekcyjny $\S \mathrm{X}$ ). Prokurator pełni swe obowiązki bezpłatnie. Niemniej, gdyby prace i zabiegi tego urzędu pociągały pewne koszta, Powiatowa Rada Opiek. i przełożona Domu SS. Mił. oznaczą ich wysokość i po zatwierdzeniu przez Władzę Duchowna pokryte zostaną $z$ funduszu zakładowego (akt erekcyjny $\S \mathrm{XII}$ ).

Gdyby $z$ jakichkolwiek względów regens Sem. Duch. obowiązków tych pełnić nie mógł, biskup kielecki zamianuje pro- 
kuratorem jednego $z$ członków kapituły katedralnej lub kolegiaty właściwej diecezji, wreszcie jednego $z$ miejscowych lub pobliskich proboszczów (akt erekcyjny $\S \mathrm{X}$ ). Ze względu na korzyść, jaką szpital odnosi z Instytucji SS. Mił., Pow. Rada Opiek., zarządzająca na mocy prawa całym szpitalem, czuwać będzie nad całością funduszu zakładowego. nad jego bezpieczeństwem i obrotem, a komisarz biskupi jest zobowiązany z pierwszym dniem stycznia każdego roku zdawać sprawozdanie Zwierzchności Szpitalnej o stanie uposażenia SS. Mił. w Kielcach (akt erekcyjny $\S \mathrm{X}$ ).

Dla ściślejszej łączności ze szpitalem i większego wpływu na jego życie, każdy prokurator będzie $\mathrm{z}$ zasady członkiem Pow. Rady Opiek.; nie jest to jednak koniecznym warunkiem tego urzędu (akt erekcyjny $\S \mathrm{XI}$ ).

Wysłany dn. 10. VIII. 1860 roku do zatwierdzenia Władz Rządowych wykaz legatów, zapisanych na rzecz SS. Mił., w łącznej kwocie R. 112250 , czyli 75000 złp., doczekał się aprobaty dopiero 26. XI. 1861 roku. Oto postanowienie Rady Administracyjnej Królestwa w pełnym i dosłownym brzmieniu:

„W Imieniu Najjaśniejszego Aleksandra II-go Cesarza Wszech Rosji Króla Polskiego etc. etc. etc.

Rada Administracyjna Królestwa.

$\mathrm{Na}$ przedstawienie Komisji Rządowej Sprawiedliwości następujące zapisy:

a) R. 3000. przez Wladysława Rudnickiego aktem na dniu 5 czerwca 1859 roku urzędownie sporządzonym.

b) R. 3000 . przez X. Eukasza Tarnawskiego na dniu 9. listōpada 1859 roku,

c) R. 1500. przez X. Macieja Majerczaka, oraz

d) R. 1500. ze składek przez tegoż zebranych, aktami na dniu 12 . czerwca 1860 roku urzedownie sporzadzonymi.

e) R. 1500. przez X. Bartłomieja Jarzębskiego aktem na dniu 9. lipca 1860 roku.

f) R. 750. przez X. Floriana Sławęckiego na dniu 17. czerwca 1861 roku.

g) R. 450. przez X. Józefa Królikiewicza na dniu 26. czerwca 1861 roku urzędownie sporządzonym -

na utrzymanie Sióstr Miłosierdzia przy szpitalu św. Aleksandra w Kielcach uczynione, w myśl Art. $910 \mathrm{~K}$. C. z zachowaniem praw osób trzecich i pod warunkami bliżej w samych aktach oznaczonymi, - zatwierdza.

Wykonanie niniejszego postanowienia Komisjom Rządowym Spraw Wewnętrznych oraz Sprawiedliwości, w czym do której należy, poleca.

Działo się $\mathrm{w}$ Warszawie dnia 26. listopada $1861 \mathrm{r}$.

p. o. Namiestnika Jenerał Adiutant (podpisano) Luders. Radca Stanu Królestwa Sekretarz Stanu (podpisano) Karnicki. p. o. Dyrektora Glównego Prezydujacego w Komisji Rządowej Sprawiedliwości (podpisano) L. Dembowski.

Zgodne $z$ oryginałem Sekretarz Stanu (-) Karnicki. - Za zgod- 
ność Naczelnik Sekcji (podpisano) Samochwałow. - Za zgodność (podpisano) Chrostowski. - Nr. 7312."

$\mathrm{Na}$ podstawie tego aprobacyjnego dekretu rządowego, biskup Diecezji Kielecko-Krakowskiej i Powiatowa Rada Opiek. sprowadzili szarytki do szpitala kieleckiego, dnia 13. V. 1862 roku.

Tymczasem od blisko dwóch lat, tj. od terminu sporządzenia aktu erekcji i zebrania zasadniczego funduszu zakładowego, na prośbę bpa Majerczaka płynęły dalsze ofiary na utrzymanie SS. Mił. Z góry trzy miesiące przed wprowadzeniem sióstr w urząd, dokładnie 2. III. 1862 roku, kwota zakładowa na utrzymanie SS. Mił. w szpitalu św. Aleksandra przybrała ostateczną wysokość R. 14809 kop. 62, czyli 98730,25 złp. Zatem do pierwszego zatwierdzonego funduszu zakładowego doszła suma R. 3559 kop. 62, czyli 23730,25 złp. Kwota ta, aczkolwiek nie zatwierdzona przez Rząd ${ }^{58}$, stanowiła razem

58 Nie ma na to dowodu ani w Aktach Konsystorskich, ani w aktach SS. Mił. Najprawdopodobniej nowe te legaty nie były wcale zatwierdzone; nie miało to zresztą istotnego znaczenia wobec wystarczającego pierwszego funduszu, oraz wobec - i to przede wszystkim - późniejszego zabrania wszystkich kapitałów szarytek przez Wladze Gubernii Kieleckiej. Jest w tym duża wina Diec. Władzy Kiel, ponieważ czy to przez zapomnienie czy to przez zlekceważenie sprawy, nie wyjednała u Rządu aprobaty aktu erekcji, który najwyraźniej zastrzega: a) że fundusz zakładowy SS. Mił. zostaje po wszystkie czasy wyłączną własnością Zgromadzenia, oraz b) że funduszem tym zarządzać będzie jedynie. Władza Duch. Diec. przez ustanowionego $w$ tym celu osobnego prokuratora (akt erekcyjny $\S$ I. i X). Z powodu braku zatwierdzenia aktu erekcji, gubernator kielecki zastosowal wobec majątku sióstr „Ukaz Najwyższy” $z$ dn. 31. VIT. 1870 roku, który orzeka, że ,majątki i kapitały, przeznaczone na utrzymanie SS. Mił. w szpitalach, założonych przez osoby prywatne, wyłączają się spod bezpośredniego zawiadywania SS. Mił. i zostają pod zarządem założycieli, ich spadkobierców, lub wyznaczonego przez nich kuratora". Po daremnych szukaniach dowodu na rządowa aprobatę aktu erekcji, po licznych konsultacjach i opiniach kapłanów, pamiętających bieg i kolejność wszystkich formalności przy założeniu Domu Szarytek, w szczególności po zeznaniu samego pierwszego prokuratora X. Józefa Gawrońskiego, że „,nie posiadam żadnych dokumentów, dotyczących potwierdzenia przez Rząd erekcji SS. Mił. w Kielcach z 1860 ioku, ani, wiem, aby kto do potwierdzenia ja przedstawial" (Akta Kons. Tom I) nowy administrator Diecezji Kielecko-Krakowskiej bkp Kuliński reskryptem $\mathrm{z}$ dn. 7. I. 1871 roku polecił X. Gawrońskiemu złożenie całego majątku szarytek kieleckich, tudziéz oddanie administracji tego majątku w ręce Kosteckiego, urzędnika do szczegółowych poruczeń przy gubernatorze kiel.; odtąd Władza, zarzadzaiąca majątkiem SS. Mi., była Rada Opiekuńcza przy Rzadzie Gubernialnym. Przewodniczacy tej Rady dn. 24. II. 1871 roku przesłal Wladzy Duch. formalne pokwitowanie odebranych kapitałów. 
z uprzednio zatwierdzonymi legatami jeden nierozdzielny i ostateczny fundusz zakładowy, z którego SS. Mił, oficjalnie korzystały. Zebraną została $\mathrm{z}$ następujących legatów:

A. 1. X. Józef Malinowski

proboszcz par. Koziegłowy w Diec. Kiel.-Krak. R. 300, czyli 2000 złp. 2. X. Michał Wiśniewski

proboszcz par. Chechlo w Diec. Kiel-Krak. $\quad$ R. 300, czyli 2000 złp. 3. X. Józef Jeleń

proboszcz par. Bolesław w Diec. Kiel-Krak. R. 300, czyli 2000 złp. 4. X. Mikołaj Stanko

proboszcz par. Chlina w Diec. Kiel-Krak. $\quad$ R. 300, czyli 2000 złp.

5. X. Karol Łokczewski

proboszcz par. Korytnica w Diec. Kiel-Krak. R. 150, czyli 1000 złp.

6. $\mathrm{X}$. Stanisław Zygmuntowicz

proboszcz par. Zlotniki w Diec. Kiel-Krak. R. 150, czyli 1000 zlp.

7. X. Jan Grządzielski

proboszcz par. Grodziec w Diec. Kiel-Krak.

8. Drobne ofiary, zebrane ōd różnych

osób na ręce bpa Macieja Majerczaka

Razem R. 150, czyli 1000 zlp.

B. Ofiary rękodajne, zebrane

przez bpa Macieja Majerczaka

C. X. Eukasz Tarnawski

proboszcz par. Kozłów w Diec. Kiel-Krak. R. 300, czyli 2000 złp.

D. Anna Bogdańska

Razem R. 3559 kop. 62, czyli 23730,24 zlp.

$\mathrm{Na}$ polecenie bpa Majerczaka, prokurator SS. Mił. X. Józef Gawroński miał - o ile możności - najweześniej dopełnić potrzebnych formalności celem przesłania nowych legatów do zatwierdzenia Rządu. Dla ułatwienia sprawy i szybszego jej biegu, zgodzili się wszyscy proszeni przez Władzę Duch. ofiarodawcy, aby zapisy ich w jednej łącznej kwocie zeznał bezimiennie wobec notariusza Administrator Diecezji pod wspólną nazwa , ofiary rękodajne na ręce X. biskupa Majerczaka złożone". W jednym terminie t. j. 17. X. 1863 roku w urzędowym akcie wobec rejenta Kancelarii Ziemiańskiej w Kielcach zeznał bp Majerczak na własność SS. Mił. sumy:

A. R. 1800, czyli 12000 złp. jako ofiary rękodaine na jego ręce złożone.

B. R. 1309 kop. 62 , czyli 8730,24 złp. jako ofiary rękodajne na jego rẹce złożone.

Tego samego dnia zeznał $\mathrm{X}$. Łukasz Tarnawski także notarialnie legat C. R. 300, czyli 2000 złp.

Aktu akceptacji powyższych sum dokonał prokurator (zgodnie $z$ \& X. aktu erekcji) w dniu 17. X. 1863 roku wobec notariusza $\mathrm{w}$ Kielcach. Wszystkie te legaty zostały ulokowane na dohrach ziemskich albo w depozycie prokuratora (suma ad B).

Bez zwłoki, dnia 20. X. 186? roku, przesłał bp Majerczak 
za pośrednictwem Komisji Rządowej W. R. i O.P. trzy legaty pod literą A, B, C do Rady Administracyjnej Królestwa z prośbą o zatwierdzenie ${ }^{59}$. Poprzednio już wspomniałem, że aprobata ta nigdy nie nadeszła.

Dziwnym zbiegiem okoliczności legat Anny Bogdańskiej, wynoszący R. 150 (1000 zlp.), oznaczony literą D i również przez Rząd niezatwierdzony, biegł oddzielną od innych zapisów własną drogą prawną, przy czym źródła nie ujawniaja nazwisk i dat, zachodzących przy poszczególnych aktach urzędowych. Pewnym jest to, że do aprobaty rządowej przedstawiony został przez Pow. Radę Opiek. ${ }^{60}$ dn. 26 . VII. 1860 roku, zatem jako pierwszy w ogóle legat jeszcze przed sporządzeniem aktu erekcji (10. VIII. 1860) i przed posłaniem do zatwierdzenia rządowego pierwotnego funduszu zakładowego $\mathrm{w}$ sumie R. 11250 , czyli 75000 złp. Tylko na mocy zasad ogólnych, stosowanych w odniesieniu do wszystkich innych legatów, $z$ cała pewnością twierdzić można, że ofiarodawczyni musiała zeznać go wobec notariusza na korzyść SS. Mił., te zaś przez S. Wizytatorkę musiały równiė $\mathrm{w}$ urzędowym akcie wobec notariusza potwierdzić akceptację legatu hipotecznie zabezpieczonego. Bez tych formalności Pow. Rada Opiek. nie mogłalby przesłać zapisu do Rządu o zatwierdzenie.

Ogólny procent roczny od całego uposażenia szarytek wynosił według racznej stopy procentowej od 4\% do $6 \%$.

Ogólny procent roczny od całego uposażenia szarytek wynosił według rocznej stopy procentowej od $4 \%$ do $6 \%$

Wydatki roczne:

sumę R. 769 kop. 38, czyli 5129,06 złp.

1. Utrzymanie 5 sióstr rocznie

2. Przeciętne koszta translokacji SS. Mił. rocznie

3. Pensja kapelana rocznie

4. Wydatki na kaplicę rocznie

Bilans:

R. 22 köp. 50, czyli 150,- złp.

Dochody roczne SS. Mił. wynoszą R. 769 kop. 38, czyli 5129,06 zlp.

Wydatki roczne SS. Mil. wynoszą

Zostaje roczna oszczędność

R. 500 czyli 3333,10 złp.

R. 30, czyli 200,- złp.

R. 180 , czyli $1200,-$ złp.

R. 732 kop. 50, czyli 4883,10 złp.

R. 732 kop. 50 , czyli 4883,10 złp.

R. 36 kop. 88 , czyli 245,26 złp.

\section{Zakres pracy, ilość, mieszkanie szarytek}

a) Zakres pracy

Jest zasadą prawa kościelnego, że w każdym zezwoleniu na założenie nowego Domu Zakonnego mieści się zgoda odnośnej

59 $\mathrm{i} 60$ Dopiero po sformułowaniu aktu erekcji Władza Diecezjalna zwracała się đo Rządu o aprobatę legatów bezpośrednio, z pominięciem Rad Opiekuńczych. (Akt er. \& X.: ,uposażenie Domu SS. Mił. w Kielcach ma zostawać pod zwierzchnictwem Władzy Diecezjalnej”). 
Władzy Duchownej na spełnienie prac i dzieł Zgromadzeniu właściwych. Chociaż akt erekcji SS. Mił. w Kielcach i umowa, warta między Powiatową Radą Opiekuńczą i S. Wizytatorką, określa istotne prawa i obowiązki szarytek, niemniej co do zakresu pracy zakonnic w szpitalu św. Aleksandra, w całej rozciągłości zachowały swą moc Reguły Ogólne i Szczególne Córek Miłosierdzia, ustanowione przez najwyższą zwierzchność Zgromadzenia i przez Władze Kościoła zatwierdzone. Reguły te służyły zresztą za podstawę przy sformułowaniu tak aktu erekcji, jak i umowy.

Według założeń twórcy Zgromadzenia Sióstr Miłosierdzia, św. Wincentego a Paulo i pierwszej przełożonej Marii Ludwiki Marillac (Le Gras), ,głównym celem, dla którego Bóg powołał i zgromadził Córki Miłosierdzia, jest uczczenie Pana Naszego Jezusa Chrystusa jako źródło i wzór wszelkiej miłości, służąc mu tak w rzeczach co do ciała, jako też i co do duszy odnoszących się, w osobie ubogich tak chorych, więźniów, dzieci, jako też i innych, które dla wstydu, ubóstwa swego okazać nie śmieją" ${ }^{61}$. W praktyce najwięcej szarytek zatrudnionych jest w szpitalach, w służbie chorych. „Służenie ubogim chorym głównym jest Córek Miłosierdzia zatrudnieniem" 62 .

Pomocnym w zorganizowaniu pracy i $w$ ustaleniu zakresu zajęć SS. Mił. w Kielcach, był przykład innych szpitali w Królestwie Polskim, w których opiekę nad chorymi pełniły szarytki, jak w Sandomierzu, Kurozwękach, a nade wszystko w Warszawie. W szpitalach tych respektowano ściśle surowe zarządzenia Władz Rosyjskich, które „Ukazem Najjaśniejszego Pana" z 2. III. 1842 roku zarząd wszystkich Instytucji Dobroczynnych oddały jedynie czynnikom świeckim; stąd pozostawały one pod władzą Rad Opiekuńczych $z$ tym, że do Pow. Rady Opiek. należała administracja, korespondencja, rachunkowość, księgowość szpitala, siostry zaś trudniły się opatrywaniem chorych i gospodarstwem domowym.

Te same zasady przyjęto $\mathrm{z}$ konieiczności przy urządzeniu szpitala św. Aleksandra w Kielcach. Rada Opiekuńcza powiatu kieleckiego, która $z$ upoważnienia Rady Głównej w Warszawie zajęła się zorganizowaniem wewnẹtrznej służby szpitala i wprowadziła w urząd SS. Mił., od såmego początku sprawowała cała administrację i kasowość, powierzając szarytkom pielęgnowanie chorych, zajęcia w kuchni, spiżarni, pralni, piw-

${ }^{61}$ Ogólne Reguty Córek Mił., rozdz. I, punkt 2.

62 Tamże, rozdz. VII, punkt 1 . 
nicy, składach szpitalnych (art. 4 umowy). Wyraźnie rozdzielił kompetencje w ten sposób prezes Rady Głównej Laszczyński, pismem $\mathrm{z}$ dnia 4. IV. 1860 roku. Ponadto do zakonnic należała troska o kaplice szpitala.

Przełożonej szarytek specjalnie powierzone zostały obowiązki intendenta szpitala (umowa art. 4). W tym względzie różnica sądów między Radą Główną z jednej, a Radą Powiatową, bpem Majerczakiem i S. Wizytatorką Joanną Schwartz z drugiej strony, nie pozwalała, poza inną jeszcze trudnością, dotyczącą chorych wenerycznie, na wczesne i bezsporne sprecyzowanie warunków umowy. Rada Główna wzorując się na wielkich szpitalach warszawskich i zaliczając do tej samej kategorii szpital św. Aleksandra, domagała się utrzymania istniejącej dotychczas w Kielcach posady intendenta. Prawdopodobnie zamierzała przez to nie tylko utrzymać większą powage szpitala, ale również ograniczyć SS. Mił. w zakresie ich zajęć. Oczywistą jest rzeczą, że hiskup i S. Wizytatorka chcieli posadę intendenta zastrzec dla miejscowej przełożonej, która łącząc te dwa urzędy, mogłaby głębiej wnikać w sprawy szpitala, a w pielęgnowaniu i żywieniu chorych, oraz $\mathrm{w}$ gospodarce szpitalnej zapewnić sobie większą łatwość i swobodę. W mocnych słowach udowadniał bp Majerczak Radzie Głównej, że skoro SS. Miłosierdzia zajmują się całym wewnętrznym gospodarstwem szpitala, intendent nie będzie miał żadnej pracy. „Ekonom w szpitalu w Kielcach, nie jest wcale to intendent, ale tylko wewnętrzny dozorca i gospodarz, a charakter ten przechodził właśnie na Siostry Mił." 69. Siostra Wizytatorka Prowincji Warszawskiej, powołując się na doświadczenia i wypróbowane zdolności szarytek w zarządzaniu dobrami ubogich, wypowiedziała się również przeciw intendentowi. Sprawę rozstrzygnęła Powiatowa Rada Opiekuńcza. Ta znając dobrze warunki lokalne, przekonała Radę Główną, że jedynie racjonalnym dla szpitala św. Aleksandra jest oddanie obowiązków intendenta przełożonej szarytek; intendentów bowiem ustanawia się $\mathrm{w}$ szpitalach wielkich, gdzie nawał prac gospodarczych zbytnio oddala siostry od właściwej im pielęgnacji chorych. W małym szpitalu kieleckim ,utrzymanie ekonoma obok SS. Mił. jest niepotrzebnym a nawet niemożliwym" ${ }^{64}$, gdyż nie dość; że nie ma dla niego istotnej pracy,

\& Z pisma bkpa Majerczaka do prezesa Rady Głównej Laszczyńskiego $\mathrm{z}$ dn. 31. VIII. 1860 roku. Akta Kons. Tom I.

${ }^{64} \mathrm{Z}$ pisma Pow. Rady Opiek. do bkpa Majerczaka z miesiąca lipca 1860 roku. Akta Kons. Tom I.

17 - Prawo Kanoniczne 
ale istnieniem swoim powodowałby jeszcze - co łatwo przewidzieć można - nieustanne przykre kolizje z szarytkami; przede wszystkim zaś likwidacji posady intendenta domaga się wzgląd na mieszkanie, jakie on w szpitalu zajmuje, a które $\mathrm{z}$ konieczności, $\mathrm{z}$ braku jakichkolwiek innych pokoi, przewidziane jest dla SS. Mił. Wobec takiej opozycji Rada Główna Opiekuńcza uważała za właściwe cofnąc swe żądanie.

Zakonnica, pełniąca obowiązki przy chorych $w$ szpitalu, nie może ograniczyć się do prac, wchodzących w zakres pielęgniarstwa. Zadanie jej jest szersze i głębsze. Do istoty jej powołania należy nie tylko troska o siły fizyczne, o zdrowie i życie chorego, co z pożytkiem czynią również ludzie świeccy, - w służbie chorym ma siostra zakonna coś z kapłaństwa, gdy zgodnie $z$ duchem Kościoła i nakazem Regul Zakonnych podsuwa choremu religijne i nadprzyrodzone motywy życia i cierpienia, godzi go $z$ wolą i opatrznością bożą, zachęca do cierpliwości, nakłania do łączności z Bogiem przez modlitwe i sakramenta św., krzepi psychiczną stronę cierpiącego przez budzenie nadziei i ufności $\mathrm{w}$ dobroć i miłosierdzie boże. Ten charakter dwojakiej pracy przy chorych, tak co do ciała, jak i co do duszy, właściwy siostrom zajętym w szpitalach, był istotnym powodem, dla którego powierzono chorych w szpitalu św. Aleksandra opiece szarytek. Ponad wszelką wątpliwość i kilkakrotnie stwierdziły to Rada Opiekuńcza Główna i Powiatowa jako Władze szpitalne, bp kielecki Maciej Majerczak i społeczeństwo miejscowe przez gubernialnego Marszałka Szlachty E. Niemojewskiego.

Siostry Miłosierdzia, objąwszy szpital kielecki, przestrzegały ściśle Reguł Zakonnych, które odnośnie chorych dają zasadnicze i wyczerpujące wskazania zarówno co do obowiązków samych, jak i sposobu ich wykonywania. I tak na mocy tych reguł udzielały chorym pomocy duchowej i fizycznej, jednej i drugiej możliwie w najszerszym zakresie.

W dziedzinie pomocy duchowej pocieszały szarytki swych chorych i dodawały im otuchy i męstwa, uczyły prawd wiary potrzebnych do zbawienia, zachęcaly do wzbudzenia aktów wiary, nadziei, miłości Boga i bliźniego, aktu żalu za grzechy, przypominały o pięknych chrześcijańskich obowiązkach pogodzenia się z nieprzyjaciółmi, przeproszenia obrażonych, oraz poddania się woli bożej $\mathrm{w}$ sprawach choroby, zdrowia, życia i śmierci. Zachęcały do generalnej spowiedzi św. i do przyjęcia sakramentów św.; uwagę nieszczęśliwych kierowały na Chrystusa, mistrza i wzór w cierpieniu, w modlitwach pole- 
cały Bogu osoby i sprawy cierpiących. Szczególną powinnością sióstr było czuwanie przy konających, podsuwanie im ostatnich formułek miłości i żalu, krótkich zawołań do imienia Jezus, do najśw. Serca Jezusowego i Matki Boskiej, modlitwa za konających i za dusze zmarłych, pomoc w ubraniu nieboszczyka i złożenie go do trumny, wreszcie skrzyżowanie rak na piersiach, obowiazzkowe odmówienie psalmu 129 „De Profundis" i pokropienie zwłok wodą święconą. „Dopełnią ten uczynek miłosierny $\mathrm{z}$ wielką skromnością i roztropnością, przypominając sobie, że Syn Boży chciał znajdować się $w$ tym stanie ${ }^{65}$. Szarytki też dopilnowywały, aby pogrzeb odprawiony został w właściwym terminie. Wszystkie motywy oddziaływania na duszę chorego mają doprowadzać do dobrej śmierci lub do naprawy życia $\mathrm{w}$ razie wyzdrowienia.

W zakresie fizycznej służby przy chorych $\mathrm{w}$ pierwszym rzędzie wykonywały szarytki całe pielęgniarstwo szpitalne, $\mathrm{z}$ wyjątkiem oddziału wenerycznego. Posługi te spełniały same bez jakiejkolwiek pomocy osób trzecich. Szczegół ten mocno akcentują Reguły Zakonne ${ }^{66}$. Podawały więc siostry chorym lekarstwa, opatrywały rany, bandażowały, przyrzadzały i podawały pokarm, poprawiały łóżka i przygotowywały je chorym do snu. Czuwały podczas nocy. Myły chorych, zmieniały bieliznę troszcząc się o jej całość i czystość. Ze zdwojoną gorliwościa miały staranie o słabych. Musiały dokładnie znać ich liczbę, uwiadomić o nich siostrę przełożoną, przestrzegać jak najskrupulatniej wskazań lekarzy odnośnie lekarstw i diety, odradzać rzeczy szkodliwych i dogadzać im ,ze słodyczą i miłością" 67. Po przybyciu nowego chorego do szpitala, myła szarytka jego ciało, głównie nogi, oczyszczała $z$ robactwa, w razie potrzeby obcinała mu włosy, zmieniała koszule i kładła go do łóżka, ogrzawszy wpierw bieliznę, po czym natychmiast uwiadamiała o nim lekarza. W specjalnie przeznaczonym na to miejscu chowała ubrania i pieniądze chorego, zapisując dokładnie ilość, aby w właściwym czasie zwrócić wszystko pacjentowi lub jego rodzinie. Artykuł 12. umowy zabranial siostrom przyjmowania do szpitala sierot i pensjonarek, a także pielęgnowania jakichkolwiek chorych $\mathrm{w}$ mieście bez względu na stan, płeć i kondycję. Zastrzeżenie to przyjęły obie strony w tym celu, aby szarytki oddały się chorym w szpitalu nie-

\footnotetext{
${ }^{65}$ Reguty Szczególne SS. Mit., zalecenia względem pogrzebów.

66 "Żadna kobieta ani dziewczyna przydatną im ku temu być nie może, aby przez zachowanie jedności między sobą, lepiej ubogim służyć mogły". Reguły szczególne dla sióstr zajętych w szpitalach.

${ }_{67}$ Reguty szczególne SS. Mit.
} 
podzielnie i całkowicie, nie szukając poza nimi innych rodzajów pracy charytatywnej nawet na terenie szpitala. Przepisem tym chroniono siostry $z$ góry przed ewentualnym zarzutem, że opiekując się bogatymi i chorymi w mieście, zaniedbują dobro szpitala i ulegają niewłaściwej szczególnie dla osób zakonnych słabości względem pieniądza i łączenia się z ludźmi zamożnymi. Nakazują siostrom Reguły Szczególne, aby wszystkich chorych leżących w szpitalu, obiegać z jednakową miłością, gorliwością i upodobaniem; wyjątek $\mathrm{w}$ tym względzie wolno stosować jedynie wobec wiẹcej cierpiących i potrzebujących serdeczniejszej, wnikliwszej opieki. Zawsze zaś „sumiennie wyistrzegać się będą dawania perwodu do cierpienia przez niedokładne $\mathrm{i}$ nieregularne niesienie potrzebnej pomocy" ${ }^{68}$.

Wyjątkowe wśród szarytek zajmowała stanowisko siostra przełożona, inaczej zwana s. służebną i to tak ze względu na ilość, jak i ważność swych kompetencji. W pierwszym rzędzie do niej należało dawanie przykładu pracy i gorliwości; „,pierwsza wypełniać będzie to, co rozkaże"69. Przełożona z urzędu swiego całym życiem sióstr i wszystkimi ich abowiązkami kierowała, pilnowała ładu i punktualności, czuwała, by każda szarytka dobrze swą powinność pełniła. Ona - jako przełożona $\mathrm{i}$ jako intendent - odpowiadała przed władzami szpitala za całe pielęgniarstwo i gospodarstwo szpitalne. Bezpośrednio też znosiła się $\mathrm{w}$ tym przedmiocie $\mathrm{z}$ lekarzami i Powiatową Radą Opiekuńczą, w sprawach duchownych z Kurią Diecezjalną, wreszcie $w$ sprawach Zgromadzenia $z$ Władzami Zakonnymi.

Przełożona osobiście winna rano i wieczorem podać chorym wodę święconą $i$ odmówić $z$ nimi pacierz. W razie niemożności zlecała tę czynność jednej z sióstr. Codziennie odwiedzała chorych zwłaszcza w godzinach rozdawania pokarmu, aby wszystkich poznać i widzieć, jakie jest chorych samopoczucie, jaki jest przebieg choroby, jakim potrzebom zaradzić. Więcej zainteresowania i opieki zobowiązywało ją wobec ciężko chorych. Pilnie zważać miała na to, aby zawsze i o każdej porze przynajmniej jedna siostra znajdowała się wśród chorych. Osobny dla swoich potrzeb miała spis wszystkich chorych, ujawniający imię, nazwisko, wiek, zawód, wyznanie, datę i miejsce urodzenia, rodzaj choroby, termin opuszczenia szpitala lub termin śmierci. Przełożona szarytek sprawo-

${ }_{68}$ Reguty Ogólne, rozdz. VII. p. 2.

$\rightarrow$ Reguły Szczególne, Zalecenia dla siostry służebnej. 
wała też opiekę $w$ charakterze bezpośredniej 'władzy nad niższą służbą szpitalną, zwłaszcza nad posługaczami i posługaczkami. Do niej wyłącznie należało prawo przyjmowania i zwalniania służących, wydawania sądu o ich moralnym prowadzeniu się, pracowitości i pośłuszeństwie (art. 10 umowy). Powiatowa Rada Opiekuńcza, w sposób specjalny to prawo jej zastrzegła, uzasadniając, że dobór odpowiednich służących wielce się przyczynia do utrzymania wewnętrznego porządku, a lepiej jak przełożona nikt służby poznać i ocenić nie potrafi (art. 10 umowy).

Pełniąc zarazem obowiązki intendenta była przełożona wewnętrznym gospodarzem szpitala i dozorcą gmachu. Zabiegała i czuwała nad regularną aprowizacją dla chorych i pracującego personelu. Troszczyła się o sprawne funkcjonowanie urządzeń gospodarczych. Miała klucze do bram szpitalnych, do drzwi wszystkich zabudowań i sal gospodarstwa wewnętrznego. Dbała o porządek i czystość w całym gmachu szpitalnym, doglądała, by wieczorem zamykano, a rano o właściwym czasie otwierano drzwi szpitala. Uprzedzała władze szpitala, aby przy końcu każdego roku, możliwie po św. Janie, przeglądnạć i skontrolować inwentarz wszystkich sprzętów, bielizny i odzieży szpitalnej celem przeprowadzenia należnych zmian, poprawek i uzupełnień ${ }^{70}$.

Wprawdzie nie przyznano szarytkom żadnego udziału w administracji i kasowości szpitala (art. 4. umowy), niemniej przełożona Domu otrzymywała na drobne wydatki pewne sumy z funduszu szpitalnego, z którego co miesiąc obowiązana była dawać sprawozdanie Powiatowej Radzie Opiekuńczej. Każdorazowa przełożona była też $z$ urzędu swego członkiem Pow. Rady Opiek. Wyróżnienie to miało ją ściślej z instytucją złączyć, przywiązać, oraz uwypuklić jej stanowisko (art. 4. umowy).

W szpitalu św. Aleksandra od samego początku jego istnienia leczono chorych wenerycznie; na mocy zaś wyraźnego zakazu fundatora św. Wincentego à Paulo ${ }^{71}$, szarytki obowiązków pielęgniarskich wobec tego rodzaju chorych nie spelniają. Rada Opiekuńcza w żadnym wypadku nie zamierzała $z$ chwilą przybycia SS. Mił. zlikwidować tego rodzaju chorych, — zresz-

70 Reguty Szczególne dla SS. Mił., pracujących w szpitalach.

71 ,Dla uniknięcia wielkich nieprzyzwoitości, jakie by mogły wyniknąć, nie będą się podejmowały czuwania przy położnicach, ani teź wspomagania kobiet złego życia”. A w razie, gdyby je o to proszono, mają się wymówić, ,że im to przez reguły ich jest zakazane". Reguty szczególne Córek Mit. dla sióstr po parafiach umieszczonych, punkt 13. 
ną najzupełniej słusznie, gdyż nie było ku temu żadnej poważnej racji. Przy dobrej woli wchodzących w grę czynników, mimo początkowej rozbieżności zdań, osiągnięto porozumienie przez przyjęcie koncepcji S. Wizytatorski, tym więcej, że Pow. Rada Opiek. nie narzucała swego poglądu, by kobietami chorymi wenerycznie opiekowaly się szarytki, a mężczyznami felczer. Zaznaczyć wypada, że Rada Opiekuńcza Zakładów Dobroczynnych Powiatu Kieleckiego wykazywała przez swego przewodniczącego Erazma Różyckiego, szerokie spojrzenie, zrozumienie, rzeczową i trafną ocenę w każdej sprawie, a przez swój wielki umiar i takt potrafiła nie dopuszczać do zaognień poglądów w kwestiach spornych; wszelkie zaś różnice sądów wyrównywała $z$ powagą, spokojem i trzeźwością. W rezultacie stanęło na tym, że oddział chorych wenerycznie, oddzielony od innych sal, tworzył odrębną całość, gdzie funkcje pielęgniarskie pełnili pielegniarze i pielęgniarki, nie zaś SS. Mił. Do pielęgniarzy też należal obowiązek utrzymania $\mathrm{w}$ czystości i w porządku bielizny i dostarczania chorym kąpieli. Szarytki natomiast przyjęly nad tym oddziałem ogólny nadzór i opiekę moralną, oraz prowadziły i dla niego wspólną dla całego szpitala kuchnię i spiżarnię (Umowa art. 5; akt erekcji § XIX).

W sprawach świeckich, dotyczących pielęgniarstwa i gospodarstwa szpitalnego, pozostawały siostry pod władzę Powiatowej Rady Opiekuńczej jako formalnej zwierzchności szpitala, i to odnośnie wszystkich praw i postanowień, wydanych dla zarządu szpitalem (art. 3 umowy). Posłuszeństwo sióstr w tym względzie winno być tak dalekie, że były zobowiązane przerwać, przyspieszyć lub opóźnić porządek swych ćwiczeń duchownych, a nawet je opuścić, jeżeli tego wymagało dobro chorych i wola władzy szpitalnej jª ${ }^{72}$ W służbie pielęgniarskiej podporządkowane były całkowicie wskazaniom i dyrektywom lekarzy, „którzy rozkażą, co im się podobać będzie" ${ }^{73}$. Na każde żądanie Władz zdawały szarytki sprawę ze swych powinności.

Zależność sióstr od Pow. Rady Opiek. nie przekreślała atrybucji Władz Zgromadzenia, które w właściwym zakresie spraw zakonnych, $\mathrm{z}$ zachowaniem wszystkich przepisów regụł, wykonywały bez pszeszkód swój urząd wobec szarytek kieleckich. Władzą, która na mocy prawa wykonywała swe kompetencje wobec SS. Mił., był Superior Generalny Kongregacji

${ }^{72}$ i $^{73}$ Reguty Szczególne dla sióstr zajętych $w$ szpitalach. 
Misjonarzy św. Wincentego à Paulo ${ }^{7 \dot{4}}$, nie zaś Ordynariusz miejsca. Nie byla tu auctoritas iurisdictionis proprie dicta, lecz autoritas administratoria. Od pierwszych dni istnienia SS. Mił. taki formalny stan rzeczy sie utrzymywal i wobec kwestionowania go przez niektórych biskupów uzyskał aprobatę najwyższych Władz Kościelnych. Dla zachowania jedności ducha i jedności rządów, dla skutecznej wszystkich szarytek działalności, wynikającej $\mathrm{z}$ ich reguł, pieczę i zarząd sprawrowało nad nimi wyłącznie Zgromadzenie XX. Misjonarzy. Wyraźne $\mathrm{w}$ tym względzie obowiązywały przepisy: pap. Pius VII przez Breve z r. 1804 orzekł: "Quum vero huic officio (nempe Superioris Generalis Missionis) adnexa est tum cura et gubernatio Communitatis Mulierum seu Puellarum Charitatis ubicumque erectae vel erigendae”. Potwierdził ten przywilej rządów XX. Misjonarzy wobec SS. Mił. pap. Leon XII w Breve $\mathrm{z}$ r. 1827: ,Itaque cum perpenderimus piissimum hos in" stitutum, quod sanctum Vincentium à Paulo parentem agnoscit in Galliis ortum, supremum eius praesulem Gallicae nationis perpetuo extitisse, eique instituto adiunctam esse administrationem societatis Puellarum Charitatis".

Ten sposób sprawowania władzy XX. Misjonarzy, zwanych popularnie Łazarzystami, z naciskiem szczególnym podkreślała zwierzchność kościelna w stosunku do SS. Mił. w Królestwie Hiszpanii ${ }^{75}$. Równocześnie papież Pius VII zastrzegal, aby nie inaczej miała się rzecz gdzieindziej poza krajami Królestwa Hiszpanii ${ }^{76}$. Ostatecznie na prośbę Superiora Generalnego XX. Misjonarzy, wniesionej za pośrednictwem Congr. Epis-

74 "Congregatio Presbyterorum Saecularium Missionis Sancti Vincentii à Paulo".

${ }^{75}$ Causis accurate perpensis, earumque agnito non levi pondere, ut... Societatis Puellarum Charitatis faciliori atque opportuniori regimini simulque maiori pauperum et infirmorum utilitati consulamus, ex certa scientia ac matura deliberatione nostris, exque apostolicae potestatis plenitudine, omnes et singulas Charitatis Puellas earumque Societates ac domos in regnis Hispaniarum a quacumque Patriarchae Indiarum, vel cuiusvis alterius iurisdietione ac subiectione prorsus eximentes ac liberantes, omnimodae iurisdictioni, obedientiae, superioritati, ac dependentiae moderni ac pro tempore existentis Vicarii Generalis Congregationis Presbyterorum Saecularium Missiones sancti Vincentii à Paulo nuncupatae, perpetuo ac integre subiicimus atque supponimus". P i us VII, Bullar. Rom. 22. VI. 1818.

${ }^{76}$ „Mandamus, ut... illa tantum regula ab omnibus et singulis nunc et in posterum observari perpetuo debeat, quae a sancto Vincentio à Paulo fundatore fuerat instituta, quaeque in Hispaniarum regnis ad nostra usque tempora retenta fuit, nihil in ea circa dictae Societatis regimem innovantes". Pius ,VII Bull. Rom. 27. XI. 1818. 
coporum et Regularium, wszystkie te przywileje Łazarzystów wobec szarytek, zatwierdził pap. Leon XIII dn. 25. VI. 1882 roku: „Nihil esse innovandum quoad regimen enuntiatae associationis Puellarum Charitatis, quod per pontificia indulta Superiori Generali pro tempore Congregationis Presbyterorum Missionis, vulgo Lasaristi, a S. Vincentio à Paulo institutae, pertinet".

Na tych prawnych podstawach i w odniesieniu do SS. Mił. w szpitalu kieleckim "curam et gubernationem” sprawowało Zgromadzenie XX. Misjonarzy. Władzę tę pełnił, podobnie jak i nad każdym Domem Prowincji Warszawskiej, X. Dyrektor. Do niego należało wizytowanie Domu Kieleckiego, znoszenie się z Ordynariuszem celem zabezpieczenia szarytkom potrzeb religijnych, wglądanie $w$ wewnętrzny zarząd Domu. On też czuwał, by tak w życiu wewnętrznym, jak i w pracy około chorych, rządziły się siostry regulą i zaleceniami Władz.

Niemniej w praktyce bezpośredni kontakt urzędowy z Domem Kieleckim utrzymywała najczęściej S. Wizytatorka Prowincji Warszawskiej, mianowana przez Władze XX. Misjonarzy. I ona miała prawo wizytowania Domu w Kielcach, wysłuchiwania sprawozdań $z$ pracy sióstr $\mathrm{i}$ kontrolowania rachunków z funduszów, przeznaczonych im na utrzymanie, oraz prawo zmiany sióstr.

Wreszcie z prawa powszechnego podlegały SS. Mił. biskupom Diecezji Kieleckiej $w$ odniesieniu do kaplicy i dzieł zewnętrznych. Rozciągał Ordynariusz miejsca jurysdykcję nad kaplicą szpitalną całkowicie, wizytował ją, zwracając uwagę na konserwację Domu Bożego, na wszelkie urządzenia wewnętrzne i przedmioty kultu. Decydował wyłącznie w sprawach kultu bożego, w szczególności o wystawieniu Najś. Sakr., o utrzymywaniu Najśw. Sakr., nakazywał odmawianie modłów publicznych, pilnował wykonywania legatów. Przedmiotem wglądu i wizytacji biskupa kieleckiego był również szpital św. Aleksandra jako opus externum SS. Mił., wszakże w granicach, nie naruszających kompetencji ani Władz Zgromadzenia, ani Władz Szpitalnych. Prawo to przysługiwało Ordynariuszowi również jako pasterzowi wszystkich wiernych w diecezji, zobowiązanemu $z$ urzędu i $z$ istoty powołania swego do szczególnej troski o dzieła chrześcijańskiego miłosierdzia. $Z$ tego samego tytułu, mimo, że formalnej jurysdykcji wobec SS. Mił. Ordynariusz nie wykonywał, roztaczał biskup kielecki ogólną opiekę nad szarytkami w Kielcach, bacząc na zasadnicze zachowanie reguły i karności klnej; o wszelkich nadużyciach zaś, jakie by zajść mogły, winien był donieść Władzom Zgro- 
madzenia lub, w razie potrzeby, Kongregacji Episcoporum et Regularium ${ }^{77}$.

Nie można pominąć, gdy mowa o służbie sióstr przy chorych, wewnętrznych motywów ich pracy. Są one wybitne chrześcijańskie, poczęte $z$ nakazów Chrystusa, z Ewangelii i stąd bodaj ze wyłącznie zakonnicom właściwe. Oderwane od świata i rodziny, Bogu poświęcone szarytki, w powołaniu pielęgniarskim kierowały się i kierować winny najszerzej i najgłębiej pojętym miłosierdziem chrystusowym, które w biednych i chorych każe widzieć samego Boga i przez nich samemu Bogu posługi spełniać ${ }^{78}$. Ten nadprzyrodzony duch chrystusowy, akcentowany nieustannie przez reguły zakonne, miał ożywić wszelką ich pracę, być im dźwignią, radością i zasługą w każdym obowiązku. Służąc chorym ,powinny jedynie widzieć Boga ${ }^{79}$, ,uczcić Pana Naszego Jezusa Chrystusa w osobie ubogich i chorych" ${ }^{80}$, uważając, „że to nie im, ale raczej Jezusowi Chrystusowi posługę oddają" ${ }^{81 . ~ G d y ~ s z a r y t k a ~ k ł a d ł a ~ c h o-~}$ rych do łóżka, miała to czynić ,,w duchu miłości i pokory, pomnąc, że jest ich sługą, a oni jej panami" ${ }^{82}$. Dając chorym pożywienie pamiętać miała, ,że to opatrzność boża zaopatruje wszystkie potrzeby ludzi" ${ }^{83}$; to znowu w czasie nocnego czuwania winna się lączyć z nocami, ,które Zbawiciel, będąc na ziemi, na czuwaniu przepędził" ${ }^{44}$. Podobne uczucia towarzyszyć miały siostrom w każdej innej powinności. Konsekwentnie zatem nakazu.ja reguły, aby wszelkiemu zatrudnieniu odpowiadały Córki Mił. ,z całym staraniem i uczuciem, do jakiego tylko zdolnymi być mogą" ${ }^{85}$, aby z chorymi i ubogimi obchodzić się ,ze współczuciem, słodyczą, serdecznością, poszanowaniem i pobożnością" ${ }^{86}$, nie zważając ,więcej na pochwały jak na obelgi" ${ }^{87}$. Jeżeli każdego człowieka uświęca praca, wynikająca $z$ jego zawodu i powołania, tym więcej pobudki i sposób codziennego służenia ubogim chorym, miały być podstawą zasadniczego bświęcenia SS. Mił.

77 Sobór tryd. na sesji XXIV., w cap. 10. dał biskupom, jako delegatom Stolicy Apostolskiej prawo wglądu w życie moralne zakōnów nawet wyjętych, oraz zobowiązał Ordynariuszy do stosowania wobec winnych sprostowań, wyjaśnień, upmnień, przestróg, kar.

78 Por. Mt. 25, 40.

79 Reguły Ogólne SS. Mił.

80 Tamże.

81 Tamże.

${ }^{82},{ }^{83}$ i ${ }^{84}$ Reguty Szczególne SS. Mił.

85, 86 i 87 Reguty Ogólne SS. Mit. 


\section{b) Ilość szarytek}

Od pierwszych chwil pobytu w szpitalu, obowiązki swe pełniło pięc SS. Mił. (umowa art. I.). Liczbę tę jako konieczną dla należytej i celowej pracy ustaliła S. Wizytatorka Joanna Schwartz ${ }^{88}$. Ona też rozgraniczyła kompetencje poszczególnych sióstr $\mathrm{w}$ ten sposób, że dwie $\mathrm{z}$ nich zajmowały się chorymi, jedna kuchnią, jedna utrzymaniem bielizny, wreszcie przełożona jako intendent zarazem troszczyła się o gospodarstwo wewnętrzne i o ogólny nadzór nad Domem. Liczba sióstr nie mogła być ani zmniejszoną ani zwiększoną bez zezwolenia Pow. Rady Opiek. jako Władzy szpitala; niemniej w razie choroby jednej z sióstr, mogła wizytatorka przysłać inną siostrę na czasowe zastępstwo po uprzednim skomunikowaniu się z Pow. Radą Opiek. (umowa art. 2). Prośbę o zmianę sióstr mogli wnosić tak Pow. Rada Opiek., jak i przełożona Domu (umowa art. 8), samą jednak zmianę przeprowadzała S. Wizytatorka. Decyzja taka w przedmiocie drastycznym i delikatnym reșpektowała pełne prawa wizytatorki, nie umniejszając w niczym słusznych żądań Władzy Szpitalnej; w praktyce właśnie ta sprawa wymagała szczególnie dużo obustronnej dobrej woli ${ }^{89}$. Jeżeli szarytka niezdobną była do pracy, czy to $z$ powodu wieku, czy to dla choroby lub kalectwa, miała prawo do pobytu $\mathrm{w}$ szpitalu i korzystania $\mathrm{z}$ mieszkania i opału po dziesięcioletniej przynajmniej służbie. Wydatki na żywność, światło i bieliznę, pokrywano $w$ tym wypadku $z$ ogólnych funduszów SS. Mił. (umowa art. 11.) ${ }^{90}$.

Ciekrawy obowiązek nałożył biskup kielecki Majerczak na duchowieństwo miejscowe $\mathrm{w}$ razie śmierci której $\mathrm{z}$ sióstr; rozporządził bowiem, aby kapłani kieleccy pochowali siostry zmarłe w szpitalu w sposób odpowiadający godności stanu zakonnego $\mathrm{i}$ to własnym kosztem i zachodem, wprawdzie wtenczas, jeżeli na koszta pogrzebu nie wystarczył ogólny fundusz. szarytek (umowa art. 14).

\section{c) Mieszkanie szarytek}

O mieszkaniu, jakie SS. Mil. zajmowały w szpitalu św. Aleksandra, są - we wszystkich odnośnych aktach - zaledwie cztery krótkie wzmianki, zamieszczone w korespondencji bkpa

${ }_{88} \mathrm{~W}$ piśmie do bkpa Majerczaka $\mathrm{z}$ dn. 5. I. 1860 roku.

89 Według Regul Szczególnych SS. Mił. Władza Szpitalna może po rocznym wypróbowaniu siostry prosić przełożonego zaḱkonnego o inną.

${ }_{90}$ Reguly Szczególne zastrzegają dla takiej siostry całkowite utrzymanie i zaopatrywanie w lekarstwa $z$ kasy szpitala, a nie $z$ funduszów SS. Mił. 
Majerczakka, Pow. Rady Opiek., Marszałka Szlachty Niemojewskiego i w art. 6 umowy. ,Mieszkania dla sióstr wystarczyłyby wygodnie" - stwierdził X. Majerczak w liście $z$ dn. 10. II. 1859 roku do wizytatora XX. Misjonarzy Prowincji Warszawskiej Dmochowskiego. Najprawdopodobniej mieszkały szarytki w trzech pokojach, tworzących odrębną całość, w głównym gmachu szpitalnym, na parterze. Jeden pokój przeznaczony był na dormitarz, drugi na refektarz, trzeci na pracownię o charakterze ogólnym. Poświęcenia mieszkania szarytek dokonal bp Majerczak 13. V. 1862 roku tj. w dniu uroczystego objęcia przez nie szpitala. Artykuł 6. umowx zapewniał siostrom mieszkanie oddzielne i bliskie służby szpitalnej. W ten sposób mogły szarytki bez trudności zachować nakazaną prawem kanonicznym i regułami zakonnymi klauzurę, oraz doglądać pracy i życia podległej im służby. Ponadto z kasy szpitala pokrywane były koszta renowacji mieszkania sióstr, oraz wydatki na opal, na fartuchy do prania i na ścierki. $Z$ iwłasnych natomiast funduszów zaopatrywały sie siostry $w$ meble i w bieliznę, opłacały równieź światło i pranie (art. 6. umowy).

\section{Kaplica szpitalna, kapelan szpitala, spowiednicy sióstr milosierdzia}

\section{a) Kaplica szpitalna}

Szpital św. Aleksandra w Kielcach, założony w r. 1828, przez dłuższy okres czasu nie miał własnej kaplicy, ani swego kapelana. Wszelkie czynności duszpasterskie, w szczególności zaopatrywanie chorych sakramentami św. i grzebanie umarłych, wykonywali księża parafialni katedry kieleckiej, na której terenie szpital się znajdowal ${ }^{91}$. Z tego tytułu duszpasterze katedry pobierali $z$ kasy szpitalnej honorarium w wysokości R. 60, czyli 400 . złp. rocznie. Dopiero z chwilą przybycia SS. Mił. (13. V. 1862) zabiegała Władza Duch. o założenie chociażby małej kalicy szpitalnej. W tym celu Administrator Diecezji Kielecko-Krakowskiej X. Maciej Majerczak, zaraz po ogłoszeniu swego zamiaru sprowadzenia szarytek i jeszcze przed objęciem przez nie opieki nad chorymi, zgodził się na erekcję kapliczki przy szpitalu. Było to w r. 1856. De-

${ }^{91}$ Od daty erekcji parafii św. Wojciecha w Kielcach, tj. od dn. 20. X. 1889 roku, szpital św. Aleksandra z racji swego położenia przypadł nowej parafii, korzystając niejednokrotnie z pomocy kaplanów przy św. Wojciechu. 
cyzją tą wyprzedził biskup świadomie i celowo przyjazd SS. Mił., chcąc od pierwszych chwil zapewnić im podstawę życia wewnętrznego. Naprzód też, zanim siostry do Kielc przyjechały, zamianował kapelana szpitalnego i wskazał dwóch spowiedników szarytek. "Niech Najw. Wizytatorka nie wątpi o szczerych chęciach Władzy Diecezjalnej, która wraz z Duchowieństwem miejscowym pracować nad tym będzie, aby Siostry Miłosierdzia przy szpitalu w Kielcach zaopatrzone zostały we wszystkie potrzeby tak materialne jak i duchowe i zasłaniane od wszelkich $\mathrm{w}$ tej mierze niedogodności" ${ }^{92}$.

Istnienie kaplicy $\mathrm{w}$ szpitalu, w którym pracowały SS. Mil., było potrzeba istotną. Umożliwiała ona i ułatwiała w sposób zasadniczy spełnianie wszystkich obowiązków powołania zakonnego. Dom boży zawsze jest centrum religijnego życia. Przepisane regułami codzienne ćwiczenia wewnętrzne, jak wysłuchanie mszy św., medytacje, nawiedzenia Najśw. Sakr., czytania duchowne, mogły szarytki pogodzić całkowicie z zajęciami szpitalnymi i pielęgniarskimi tylko dzięki najbliższej, bezpośredniej odległości do kaplicy. W ten sposób zawsze byly na miejscu, w obrębie gmachu i w razie potrzeby łatwo osiągalne. Każdej też chwili mogły podjąc wszelkie właściwe prace bez szkody dla swego wyrobienia wewnętrznego i dla dobra szpitala.

Nie samym siostrom służyła kaplica. Bliskość żywego Boga dodawała namaszczenia i powagi całej Instytucji. Personel szpitalny i służba mogli bez trudu wysłuchać niedzielnej i świątecznej mszy św. i częściej przyj̣mować sakramenta św. Chorzy zapewnioną mieli specjalną opiekę duszpasterską dzięki kapelanowi, który z urzędu swego troszczyć się musiał o ich dusze tak, jak proboszcz o swych parafian; regularnie więc byli zaopatrywani w sakramenta św., mieli możność częstszego spowiadania się i codziennego przyjimowania komunii św. tak w kaplicy, jak i w salach szpitalnych.

Pierwsza kaplica przy szpitalu św. Aleksandra w Kielcach, powstała w r. 1856 za zezwoleniem Administratora Diecezji Majerczalsa. Była to zapewne kaplica publiczna ${ }^{93}$. Tenże bp Majerczak najprawdopodobniej kaplice tę poświęcił, konsekrując równocześnie jedyny ołtarz ${ }^{94}$. Byla to kapliczka bardzo

$92 \mathrm{Z}$ pisma kbpa Majerczaka do wizytatorki SS. Mił. Joanny Schwartz $\mathrm{z}$ dn. 17. IX. 1860 roku. Akta Kons. Tom I.

${ }_{93}$ Kaplice przy szpitalach, jako Instytucjach $z$ natury swej publicznych, miały $z$ reguły prawa kaplicy publicznej. Por. Ferrari J., Summa Institutionum Canonicarum, Tom II, nr 447.

${ }_{94}$ Dokładnych szczegółów, odnoszących się do pierwszej kaplicy szpitalnej, odnośne akta nie ujawniają. 
mała, prawdopodobnie murowana, mogąca pomieścić kilkanaście osób. Dobudowana na parterze od strony zachodniej, w środku głównego gmachu szpitalnego i złączona $z$ gmachem przez drzwi do korytarza, naprzeciw głównego wejścia od ulicy, stanowiła odrębną całość. Wzniesioną i urządzoną została z dobroczynnych ofiar miejscowej ludności, głównie dzięki zabiegom prezesa Pow. Rady Opiek. Erazma Różyckiego, X. Leopolda Dobrzańskiego z Kielc i Antoniego Dobrzańskiego, członka Pow. Rady Opiek., sprawującego w jej imieniu nadzór nad szpitalem. Funkcje kapłańskie pełnili w niej duszpasterze parafii katedralnej.

Kapliczka ta ze względu na szczupłe rozmiary, nie mogła służyć potrzebom całego szpitala. Z przybyciem sióstr, gdy duszpasterstwo szpitalne sprawowal oddzielny kapelan, a chorzy, szarytki i służba szpitalna schodzili się codziennie na mszę św. i na modlitwy, $z$ konieczności musiano pomyśleć o gruntownej przebudowie i znacznym rozszerzeniu pierwotnego domu bożego. Ze szczególną troskliwością krzątali się około tego dzieła prokurator SS. Mił. X. Józef Gawroński i pierwsza przełożona szarytek S. Wiktoria Postkowska, dzieląc funkcje $\mathrm{w}$ ten sposób, że prokurator $\mathrm{z}$ urzędu zbieral potrzebne fundusze i materiały budowlane, przełożona zas, będąc najbliżej samej sprawy, całą budową bezpośrednio kierowała.

$\mathrm{Na}$ miejscu pierwotnej kapliczki powstała w roku 1867 kaplica druga, nowa i znacznie większa. Była to kaplica publiczna ${ }^{95}$, te same więc co do kościołów, odnosiły się do niej przepisy prawne ${ }^{96}$. Założenia i poświęcenia kamienia węgielnego pod nową kaplicę, dokonał Administrator Diecezji bkp Majerczak dnia 10. VIII. 1867 roku, stosownie do wymagań prawa kościelnego ${ }^{97}$. Było to formalne aprobowanie właściwego miejsca pod dom boży ${ }^{98}$ tak, aby stanowił odrębną dla siebie całość, wolny był od wszelkich czynności świeckich, a zwłaszcza od bezpośredniego sąsiedztwa z pokojami sypialnymi ${ }^{99}$. Przy

95 Por. Rocznik Diecezji Kieleckiej $z$ r. 1893; Por. Ferrari J., dz. cyt. Tom II, nr 447.

${ }_{96}$ Por. I c a r d H., dz. cyt. Tom II, nr 548; J. F e r r a r i, dz. cyt. Tom II, nr 447; Wernz Fr., dz. cyt. Tom III, nr 455.

${ }^{97}$ Por. Decr. Grat. Can. 9 Dist. I De Cons.; Rit. et Pontif. Rom.

99 "Vide, ne offeras holocausta in omni loco quem videris, sed in omni loco, quem elegerit Dominus Deus tuus". Papa Felix IV, apud Grat.

${ }_{90}$ Por. S. Rituum Congr. 11. V. 1641; 12. IX. 1840; 31. VIII. 1867: 23. XI. 1880; Concilium Mediolanense VI prohibuit, ne „A parte superiori vel coenaculum, vel cubiculum, vel omnino locum habeat, ubi aut 
założeniu kamienia węgielnego naznaczono kaplicy tytuł Niepokalanego Poczęcia N.M.P. ${ }^{100}$ Tytuł ten nigdy już nie był zmieniony ${ }^{101}$.

Konsekracja kaplicy odbyła się $\mathrm{w}$ wigilię święta Niep. Poczęcia N.M.P., 7. XII. 1867 roku. Obrzędu tego według rytu, przepisanego przez Pontyfikał Rzymski, dopełnił osobiśsie bp Majerczak wobec przedstawicieli Pow. Rady Opiek., personelu szpitalnego, SS. Mił. i licznie zgromadzonych wiernych. W przeddzień konsekracji, 6. XII. 1867 roku tak konsekrator jak i SS. Mił., personel i służba szpitalna zachowali post ścisły, a wieczorem odmówiono przed świętymi relikwiami pierwsze nieszpory Dedicationis Ecclesiae. Konsekracja kaplicy ${ }^{102}$, a nie benedykcja tylko, miała nadać aktowi religijnemu większego splendoru i podnieść znaczenie kaplicy szpitalnej. Uroczystość ta odbyła się według rygorów prawa klnego, odnoszących się do loca sacra, $\mathrm{z}$ zachowaniem praw Ordynariusza ${ }^{103}$ Diecezji. Przez konsekrację, która $z$ istoty swej jest ceremonią liturgiczną, została kaplica oddana wyłącznie na cele kultu religijnego. Od tej dopiero chwili mogła w niej $\mathrm{w}$ sposób godziwy odprawiać się msza św. ${ }^{104}$. Wszelkich czynności świeckich w Domu Bożym prawo zabraniało ${ }^{105}$. Corocznie też tak jak w konsekrowanych kościołach, obchodzono

dormiatur, aut habitetur, aut quidquam profani fiat". „Antiqua disciplina constitutum est, ut oratoria in loco decenti et honesto, atque ab omnibus usibus domesticis libero extruantur. Iustam habeant amplitudinem, nullum supra debet existere cubiculum, in quo lectus cuiquam sternatur". Rituale Ecclesiae Parisiensis.

${ }_{100}$,Sanctum vel sanctam, in cuius honorem ac nomen fundabitur ecclesia". Rit. Rom. Por. S. Congr. Rituum 27. I. 1857.

101 Por. I c a r d H., dz. cyt. Tom II, nr 555.

$102 \mathrm{~S}$. Rituum C. nigdy nie zakazywała konsekracji kaplic publicznych, nawet w poszczególnych wypadkach, a 23. I. 1899 roku wyraźnie na to zezwolita. Por. We r $\mathrm{z}$ Fr., dz. cyt. Tom IIT, nr 453.

${ }^{103} \mathrm{X}$. Majerczak rządzif Diecezją Kielecko-Krakowska od r. 1849 do 1870. Sakre bkpią otrzymał w r. 1862. Był zatem w zrozumieniu prawa jako Wikariusz Apost. Ordynariuszem, upoważnionym do konsekracji kościołow i kaplic. Por. I c a r d H., dz. cyt. Tom I, nr 122; Wernz Fr., dz. cyt. Tom II, nr 704; Por. Pontif Rom. P. II, Tit. De Ecclesiae dedic. seu cons.; Leon $\mathrm{X}$ Const. .Dum intra” 19. XII. 1516; Conc. Trid. Sess. VI. cap. 5. De Reform: S. Congr. De Prop. Fide 1. XII. 1837 De Patriarchis.

${ }^{104}$,Missarum celebrationes non alibi quam in sacratis Domino locis, absque magna necessitate fieri debere liquet omnibus, quibus nota sunt Veteris et Novi Testamenti praecepta". Pap. Felix IV. apud Grat. c. I. Dist. I. De cons; najpóźniej też od VI w. istnialy kanony, które surowo zakazywały odprawiania mszy św. w kościołach nie poświeconych (C. 23. Syn. S. Patricii a. 450-456).

105 Por. Wernz Fr., dz. cyt. Tom III, nr 454. 
w szpitalu w dniu 8 grudnia uroczystości konsekracji kaplicy ${ }^{106}$ i równocześnie uroczystość tytułu kaplicy ${ }^{107}$. Był to jakoby Dies Natalis ac Nomen Baptismale Ecclesiae sub ritu duplici primae classis cum octava.

Nie pozostawia najmniejszej wątpliwości, że bp Majerczak wyraził swą zgodę, wymaganą przez prawo klne, konieczną do ważności erekcji nowej kaplicy publicznej ${ }^{108}$. Dowodu na to - z braku aktu erekcyjnego - dostarczał fakt, że bp założył i poświęcił kamień węgielny, oraz kaplicę konsekrował $\mathrm{i}$ to po uprzednim stwierdzeniu, że zbudowaną została na właściwym miejscu, oraz według liturgicznych przepisów i ducha Kościoła. Wprawdzie pierwotna kaplica prawdopodobnie była nie konsekrowana, lecz benedykowana; straciła jednak swą benedykcję, ponieważ całkowicie została zniesiona i poza samym miejscem nic jej z drugą kaplicą nie łączyło ${ }^{109}$. Stąd tak poświęcenie kamienia węgielnego pod nowy Dom Boży, jak i jego konsekracja (względnie benedykcja) była koniecznością prawną. Żadne istotne trudności nie stanowiły przeszkody dla consensus episcopi; istniała bowiem wymagana prawem dla erekcji kaplicy iusta causa ${ }^{110}$, którą była commotitas plebis ac magna utilitas hospitii, oraz wystarczające fundusze na budowę i utrzymanie Domu Bożego ${ }^{11}$.

Nowa kaplica posiadała trzy ołtarze, wielki-główny i dwa boczne. Ołtarz wielki był stały (immobilis), oba zaś boczne prawdopodobnie przenośne (mobiles vel portatiles). Równocześnie z ceremoniami konsekracji kaplicy, dokonał bp Majerczak jako Ordinarius loci konsekracji wszystkich najprawdopodobniej ołtarzy, a conajmniej konsekracji ołtarza wielkiego. Obrzęd ten był koniecznością prawną ${ }^{112}$. Był też niezbędnym warunkiem godziwego odprawiania mszy św. Tra-

106 Por. S. R ituum C. 14. VI. 1608, 18. VIII. 1629, 13. III. 1649, 29. VII. 1780 ad 3; Por. Ferrari J., dz. cyt. Tom I, nr 443.

107 Według S. Aichnera festum tituli obchodzi się tylko na mocy zwyczaju, nie na mocy prawa. Por. Compendium Juris Ecclesiastici 692 ad 2 ; We r n z Fr., dz. cyt. Tom III, nr 453.

108 Por. Ferrari J., dz. cyt. Tom II, nr 441; H. Icard, dz, cyt. Tom

II, nr 548; Bened. XIV, Const. "Quamvis iusto" 30. IV. 1749; S.C.C.

8. VII. 1707, 14. VIII. 1861.

109 Por. Ferrari J., dz. cyt. Tom II, nr 444; I c a r d H., dz. cyt.

Tom II, nr 556; Bened. XIV Const. "Iam inde" 12. V. 1756 \& 13.

110 Por. Conc. Trid. Sess. XXI. cap. 4. De Reform; por. Ferrari J.,

dz. cyt. Tom II, nr 441; W ernz Fr., dz. cyt. Tom III, nr 452; A i ch-

ner S., dz. cyt. 696 ad 2.

111 Por. Aichner S., dz. cyt. 696 ad 2.

112 Por. S. Rit. C. 19. IX. 1665, 24. V. 1844, 23. I. 1844, 23. I. 1850 , 31. VIII. 1872. 
dycja taka utrzymywała się w Kościele od starodawnych czasów apostolskich ${ }^{113}$ do tego stopnia, że kapłan, który by świadomie poza wypadkiem największej konieczności lub bez zezwolenia Stolicy Apostolskiej, odważył się celebrować na ołtarzu nie konsekrowanym, ciężko by zgrzeszył i byłby suspensus a divinis ${ }^{114}$.

Za wzorem kościołów, w których każdy ołtarz, a przynajmniej ołtarz stały ma swój tytuł i przez to jest poświęcony czci jakiegoś świętego, lub jakiej tajemnicy wiary, wszystkie trzy ołtarze w kaplicy szpitalnej otrzymały przy konsekracji odrębne tytuły, na które wskazywały umieszczone na poszczególnych ołtarzach malowane obrazy. Ołtarz główny poświęcony był czci Matki Boskiej Niep. Poczętej; miał zatem ten sam tytuł co i kaplica: Jeden ołtarz boczny od strony ewangelii poświęcony był czci Chrystusa Ukrzyżowanego, drugi od strony epistoły św. Wincentemu à Paulo. Tak ołtarze jak i cała kaplica służyły wyłącznie celom kultu religijnego i służby bożej, w szczególności ofiarze mszy św. z zachowaniem przepisów liturgicznych i $z$ wykluczeniem wszelkich czynności świeckich.

Wszystkie fundusze, dzięki którym kaplica powstała, pochodziły $z$ dobrowolnych składek i ofiar. Dobroczynność publiczna w tym wypadku podobnie jak przy gromadzeniu funduszu zakładowego na SS. Mił., dopisała w zupełności. Ofiary składali kapłani z Kielc i z diecezji kieleckiej, oraz niektóre pobożne osoby $\mathrm{z}$ miasta $\mathrm{i}$ okolicy. Kilkanaście nazwisk ofiarodawców jest nieznanych. Oprócz pieniędzy w gotówce płynęły też ofiary w formie materiałów budowlanych; wszystkie kierowane były na ręce prokuratora, albo wprost do przełożonej szarytek Specjalną ważną część darów stanowiły uiszczone przez różne osobistości koszta za wewnętrzne artystyczne ornamentacje kaplicy, oraz darowane obrazy. Wykaz wszelkich darowizn na budowę i urządzenie kaplicy szpitalnej obejmuje:

a) $\mathrm{W}$ gotówce:

1. X. Bartłomiej Jarzębski, b. proboszcz w Szkalbmierzu, dnia 29. V. 1862 roku R. 300 , czyli 2000 zlp.

2. Katarzyna Wawrzecka, zam. w Kielcach, dnia 27, III. 1859 roku R. 63 kop. 45 , czyli 423 złp.

3. Procent od powyższych sum za czas od 1. VII. 1862 do 18. VII. 1867 wynosił R. 72, czyli 480 złp.

4. Inni nieznani ofiarodawcy R. 502 kop. 25, czyli 3348, 10 złp.

113 Por. I card H., dz. cyt. Tom II, nr 559.

114 Por. Fer r a r i J., dz. cyt. Tom II, nr 451. 
Razem R. 937 kōp. 70, czyli 6251,10 złp.

b) $\mathrm{W}$ innych darach:

1. Strycharze kieleccy 7 tysięcy cegieł. 2. W. Nowosielska, dziedziczka Szczecna w powiecie kieleckm, wszystko drzewo potrzebne do budowy kaplicy. 3. Rafał Hadziewicz, b. profesor malarstwa w Warszawie trzy własnego pędzla obrazy, umieszczone w ołtarzach, obraz. Matki B. Niep. Pocz., Chrystusa Ukrzyżowanego, św. Wincentego à Paulo. 4. Aleksander Bronikowski, obrońca Prokuratorii z Kielc, obraz Najśw. Maryi Panny. 5. Dr Stefan Łuszczkiewicz, ordynujący lekarz w szpitalu św. Aleksandra. 6. Lutnicki, obywatel kielecki. 7. Helena Piegłowska. 8. Serafiński, zegarmistrz $\mathrm{z}$ Kielc. 9. Inne nieznane osoby własnym nakłardem pokryli wewnętrzne ornamentacje kaplicy. 10. Biskup kielecki X. Maciej Majerczak, dnia 16. X. $186 \overline{2}$ roku, kielich srebrny i patenę miedzianą pozłacaną.

Istotnym warunkiem koniecznej erekcji kaplicy, było zawsze odpowiednie uposażenie, wystarczające na budowę, konsekrację i utrzymanie kaplicy, oraz na cele kultu. Przepisy władzy kościelnej są wyraźne w wypadku gdy kto występuje z projektem budowy kościoła czy kaplicy ${ }^{115}$. Przepisami swymi zabezpieczał Kościół Domom Bożym należyty wyglą i chronił je przed zaniedbaniem i opuszczeniem 116. W dniu poświęcenia katmienia węgielnego poid nową kaplice, miał bp kielecki moralną pewność, że fundusze już zebrane i te które $z$ wszelkim prawdopodobieństwem jeszcze wpływać będą, zabezpieczą całkowicie wzniesienie i samo wykończenie budowy kaplicy. Na utrzymanie zaś Domu Bożego i na wszelkie wydatki, związane $z$ kultem, zapewniona była już 10 . VIII. 1860 roku ${ }^{117}$ roczna suma $R$. 22 kop. 50, czyli 150 złp. Ponadto celom kaplicy służyły ofiary wiernych, obecnych na nabożeństwach.

Druga $z$ rzędu kaplica przy szpitalu św. Aleksandra, oddana na służbę bożą 7. XII. 1867 roku i do dziś istniejąca, wzniesioną została jako oddzielna dobudowa na miejscu starej kapliczki, różniąc się znacznie od pierwszej rozmiarami i bogactwem urządzenia wewnętrznego. Położona od strony zachodniej $\mathrm{W}$ stosunku do szpitala, złączona była $\mathrm{z}$ głównym gmachem tylko przez dr̈zwi, wychodzące na sam środek korytarza na panterze. W ten spposób prostopadle dor kaplicy umieszczone były od strony wschodniej gmaichu główne wejściowe drzwi szpitalne tuż przy ulicy Tadeusza.

$\mathbf{1 1 5}$,ostensa donatione, praefiniat, quae ad luminaria et ad custodiam et ad stipendia custodum sufficiant". Decr. Grat., can. 9, Dist. I de cons.

116 Por. A i chner S., dz.cyt . pag. 696 ad 2.

117 Data sporządzenia aktu erekcji Domu SS. Mił. przez bkpa Majerczaka i przez Pow. Radę Opiek.

18 - Prawo Kanoniczne 
Projekt i plan budowy kaplicy wykonał Kowalski, budowniczy guberialny. Cała $\mathrm{z}$ kamienia i cegły, zbudowana była $\mathrm{w}$ formie prostokąta $\mathrm{z}$ zaokrąglonym półkolem $\mathrm{w}$ części zachodniej, gdzie stał wielki ołtarz. Liczy $18 \mathrm{~m}$. długości, 10 $\mathrm{m}$ szerokości, $10 \mathrm{~m}$ wysokości. Uwzględniając urządzenia wewnętrzne, pomieścić może około 200 osób na powierzchni $180 \mathrm{~m}^{2}$. Dach pokryty był blachą; ze wschodniej jego części, a więc nad wejściem $z$ korytarza szpitalnego do kaplicy, wznosi się trzymetrowa wieżyczka z sygnaturką o średnicy $30 \mathrm{~cm}$ i z Krzyżem, stojącym na kuli na samym szczycie ${ }^{118}$. Całość wykazuje styl barokowy z licznymi ornamentacjami i bogactwem, widocznym szczególnie wewnętrz Domu Bożego.

Wspaniałością kaplicy i największą jej ozdobą, jest wielki ołtarz, pierwsze wedle myśli Kościoła zajmujący w Domu Bożym miejsce. Cały wraz $z$ podstawa (stipes) i $z$ zewnętrzną powierzchnią (mensa) $z$ pięknego białego marmuru. Spoczywa on na dwóch dużych i okazałych z białego marmuru plytach, będących stopniami ołtarza. Marmurowe też i białe jest tabernakulum z mosiężnymi drzwiczkami. Mensa, wylkonana $z$ jednolitej naturalnej bryły marmurowej, przylega do całej powierzchni ołtarza, tworząc z nim jedna całość; stąd konsekrowana była razem $\mathrm{z}$ marmurową podstawą, dzięki czemu oltarz wielki jest oltarzem stałym ${ }^{119}$. Z bolków oltarza wznoszą się w górę dwie trzymetrowe kolumny, również z białego marmuru, zakończone marmurowym daszkiem. W środku między kolumnami znajduje się obraz Matki Boskiej Niep. Pocz. - rozmiarach 105 razy $167 \mathrm{~cm}$. pędzla Rafała Hadziewicza z Warszawy; Niepokalana bowiem jest tytułem wielkiego oltarza. Nad obrazem M. B. Niepokalanej, również między kolumnami, na wysokości daszka, umieszczono olejny obraz $\mathrm{w}$ kształcie koła o średnicy $80 \mathrm{~cm}$. Przedstawia on popiersie św. Józefa. Nad obrazem wznosi' się biały marmurowy Krzyż bez pasyjki.

Prowincjonalne władze szarytek wyjednały dla kaplicy od najwyższych Władz Zgromadzenia w Paryżu relikwie św. Wincentego à Paulo, które przesłał do Kiclc Przełożony Generalny $\mathrm{X}$. Etienne wraz z dokumentem autentyczności. Biskup

118 Początkowo, gdy szpital miał tylko parter i pierwsze piętro, kaplica $\mathrm{z}$ wieżyczką wyodrebniała się $\mathrm{z}$ daleka na tle niższego gmachu; później jednak, gdy w r. 1939 dobudowano drugie i trzecie piętro, Dom Boży, niższy i rozmiarami mniejszy, stracił dużo optycznie przy wielkim gmachu szpitalnym.

110 Por, Ferrari J., dz. cyt. Tam IT, nr 451; I c a rd H., dz. cyt. Tom II, nr 559; Aichner S., dz. cyt. 704 ad 1 . 
Majerczak, stwierdziwszy rzeczywistą autentyczność relikwii, zaaprobował je i pozwolił umieścić w ołtarzu wielkim i - co jest prawdopodobne - równiez $w$ obu bocznych ołtarzach. Bez świętych relikwii nie wolno było ołtarza konsekrować ${ }^{20}$. Blisko oltarza przy ścianie po stronie epistoły, stał mały marmurowy stół dla przedmiotów, służących celom kultu.

Prezbiterium wyższe od reszty kaplicy o jeden stopień, oddzielone jest balustradą, której piękno stanowią żelazne kolumienki w formie lilijek i dwie długie białe płyty marmurowe, jedna jako górna powierzchnia balustrady, druga umieszczona u jej nasady, potrzebna jako stopień przy klękaniu. Dzięki znacznemu podwyższeniu trzech stopni w stosunku do głównej nawy, jest ołtarz wielki doskonale widoczny i wszyscy obecni na nabożeństwie dokładnie mogą śledzić odbywające się przy nim funkcje liturgiczne. Obfitość marmuru daje całemu prezbiterium wraz $z$ ołtarzem wygląd estetyczny, harmonijny, nie usuwając mimo bogactwa wrażenia prostoty.

Nawę kaplicy zdobią dwa ołtarze boczne $z$ białego marmuru i prawdopodobnie przenośne (ara portatilis seu mobilis). Podstawa ich przymocowana jest wprost do posadzki, z przodu zaś do każdego $\mathrm{z}$ nich dosunięty jest jeden stopień drewniany, na którym kapłan stoi, odprawiając mszę św. W jednym i drugim umieszczone są marmurowe płyty (petra sacra), które kryją relikwie. W ołtarzu po stronie epistoły, poświęconym czci założyciela szarytek św. Wincentego à Paulo, jest obraz tego świętego o rozmiarach 100 razy $163 \mathrm{~cm}$, pędzla Rafała Hadziewicza z Warszawy. Tej samej wielkości obraz również pędzla Rafała Hadziewicza znajduje się w drugim ołtarzu bocznym po stronie Ewangelii, a przedstawia Chrystusa Ukrzyżowanego jako tytuł ołtarza. $\mathrm{Na}$ suficie widnieją trzy olejne malowidła nieznanego pędzla. Jedno duże $w$ owalu, 0 wymiarach $3 \times 2 \mathrm{~m}$, przedstawia Zwiastowanie N.M.P. Maryja, klęcząc przyjmuje poselstwo archanioła Gabriela. Dalej, prawie już nad chórkiem, namalowany jest do połowy św. Karol Boromeusz $\left(1,10 X_{i} 80 \mathrm{~cm}\right)$; po przeciwległej zaś stronie $\mathrm{w}$ tej samej wielkości i $\mathrm{w}$ tym samym układzie przedstawiona jest św. Jadwiga.

Od tylnej ściany kaplicy idą ku balustradzie dwa rzędy dużych, wygodnych ław po $5 \mathrm{z}$ każdej strony. Po przeciwległej stronie wielkiego ołtarza nad drzwiami do kaplicy, urządzony został chórek z małymi organami. Wejście do niego prowadzi

${ }_{180}$ Por, S. Rit. C. in caus. Rhed. 23. IX. 1837 et $6 . \mathrm{X} .1837$; in caus. Fanon. 17. VI. 1843. 
przez drzwi z korytarza na pierwszym piętrze szpitala. Dokoła na ścianach kaplicy rozwieszone są malowane na płótnie, oprawne w ramy stacje Drogi Krzyżowej. Oświetlenie kaplicy stanowią cztery duże okna witrażowe. Dwa $z$ nich umieszczone są $\mathrm{w}$ prezbiterium; jeden po prawej stronie wyobraża św. Antoniego z Padwy, drugi z lewej strony św. Stanisława Kostkę. W nawie oba witraże wznoszą się nad bocznymi ołtarzami i przedstawiają święty medalik w ten sposób, że nad ołtarzem św. Wincentego à Paulo widnieje litera $\mathbf{M}$, nad nią Krzyż i dwa serca pod litera, a nad ołtarzem Chrystusa Ukrzyżowanego postać M. B. Niepokalanej.

Ponadto $\mathrm{z}$ chórku wychodzą dwa zwyczajne okna na korytarz szpitalny na pierwszym piętrze. Posadzka tak $w$ nawie jak i w prezbiterium ozdobiona została kaflami terakoty, ułożonymi w gwiazdy.

Osobne miejsce zajmuje zakrystia. Stanowi ona oddzielną dobudowę, od południowej strony kaplicy, z kktórą złączona jest przez drzwi. Równolegle też do wejścia z korytarza szpitalnego do kaplicy, prowadzą drzwi z tego samego korytarza do zakrystii.

Kaplica zaopatrzona była obficie we wszystkie paramenty kościelne i przedmioty kultu, nie wyłączając monstrancji, żłóbka i Grobu Pańskiego. Utrzymywanie porządku w kaplicy i troska o całość przyborów do służby bożej, należała do siostry przełożonej (akt er. § XVII). Ona też dostarczała potrzebnych utensyliów jak wina, opłatków, oliwy itp., a wszystkie pieniądze $\mathrm{w}$ tym celu, pobierała $\mathrm{z}$ funduszu ogólnego SS. Mił., w którym przewidziana ibyła sulma R. 22 koip. 50, czyli 150 złp. na roczne wydatki dla kaplicy (akt er. § XVII).

\section{b) Kapelan szpitala}

Jak w każdym szczególe, odnoszącym się do SS. Mił., tak w urządzeniu kaplicy i w dziedzinie szpitalnej opieki religijnej, znać przemyślenie oraz trwałe i rzeczowe zaspokojenie wszystkich potrzeb. Dom Boży i duszpasterstwo nad całym szpitalem wymagały kapłana, który by stale odprawiał nabożeństwa i każdej chwili pełnił właściwe posługi duchowne. Temu zadaniu miał służyć osobny kapelan jako zasadniczy i $z$ urzędu swego duszpasterz szpitalny. Dodatkowo potrzebni byli jeszcze dwaj kapłani przeznaczeni wyłącznie do spowiadania szarytek.

Było życzeniem bpa Majerczaka, aby kapelan szpitalny był równocześnie zwyczajnym spowiednikiem SS. Mił. Nie sprzeciwiało się to prawu klnemu; wnet jednak ustąpił biskiup ze 
swego zdania i to na wyraźną prośbę dyrektora XX. Misjonarzy Warszawskiej Prowincji, X. Dmochowskiego, który zastrzegł sobie, by kapelanem był kapłan oddzielny od spowiednika sióstr. Inaczej tak kapelan jak $\mathrm{i}$ siostry byliby wzajemnie krępowani i pozbawieni koniecznej swobody w działaniu i niezależności w pracy. Niemniej kapelan szpitala był zarazem kapelanem Domu szarytek; spełniał zatem posługi duchowne chorym, leżącym w szpitalu i zakonnicom, - z wyjątkiem spowiadania SS. Mił., oraz dla jednych i drugich odprawiał nabożeństwa. Wyznaczał go i aprobował Wikariusz Apost. i Administrator Diecezji Kielecko-Krakowskiej. Od Ordynariusza też był kapelan jedynie i całkowicie zależny. Pierwszym kapelanem SS. Mił. przy szpitalu św. Aleksandra był X. Kapistran Łukasiewicz, prawdopodobnie $\mathrm{z}$ zakionu reformatów.

Wszystkie prawa i obowiązki kapelana określało nie tyle prawo ogólne, w tej dziedzinie jeszcze nie ujednolicone, ile zwyczaje i praktyka $\mathrm{w}$ danej diecezji czy w danym kraju, prawo fundacyjne i zarzaddzenia bpa ${ }^{121}$. Posiadał kapelan na swoim terenie władzę podobną do władzy proboiszcza (iurisidictio quasiparochialis) i tak wolbec chorych i personelu szpitalnego, jak i wobec SS. Mił. pełnił formalnie curam animarum. Wprawdzie Sobór Trydencki postanowił ${ }^{122}$, aby biskupi podzielili swe diecezje na ściśle określone parafie i, aby każdy z proboszczów pełnił władzę duszpasterską wobec wszystkich swoich parafian; niemniej $\mathrm{w}$ Domach Zakonnych i w Instytucjach takich jak szpitale, sierocińce, więzienia itp., władzę tę pełnić mógł również kapelan, przez biskupa ustanowiony ${ }^{\mathbf{1 2 3}}$. Życie samo stworzyło tę praktykę; proboszcz bowiem sam czy to przez swego wikariusza nie mógł zaspokajać stale wszystkich potrzeb duszpasterskich w różnych Zakładach i Instytucjach, leżących w jego parafii.

Był więc kapelan zobowiązany odprawiać codziennie w kaplicy mszę św., w niedziele i święta głosić kazania, spowiadać i udzielać komunii św., chorych opatrywać sakramentami św. i - jeżeli to możliwe - uczyć rekonwalescentów katechizmu (akt er. § XVI). Mógł udzielać ostatnich sakramentów św. tj. wiatyku i namaszczenia olejami św. wszystkim chorym i Siostrom Miłosierdzia ${ }^{124}$. Mocno prerogatywy proboszcza podkreśla prawo kościelne w sprawie pogrzebów, także wobec zakonnic w sprawach duszpasterskich nie wyjętych spod

121 Por. A i chner S., dz. cyt. 704.

122 Por. I card H., dz. cyt. Tom I, nr 260.

123 Conc. Trid. Sess. XXI. cap. 4. De Reform.; Por. A i chner S., dz. cyt. 452; I c a r d H., dz. cyt. Töm I, nr 260.

124 Por. I c a r d H., dz. cyt. Tom I, nr 261. 
ich władzy ${ }^{125}$. W tym względzie kapelan szpitala św. Aleksandra zależał $\mathrm{w}$ zupełności od miejscowego proboszcza ${ }^{126} \mathrm{i}$ mógł grzebać zmarłych w szpitalu tak świeckich jak i szarytki tylko za zgodą właściwego proboszcza. Nie należało też do kcmpetencji kapelana ważne udzielanie ślubów; i w tej materii zależał on całkowicie od miejscowego proboszcza ${ }^{127}$. Szczególnym obowiązkiem sumienia była dla kapelana troska o Najśw. Sakrament. Polegała ona na utrzymaniu w czystości tabernakulum, przechowywaniu klucza od tabernakulum, odnawianiu postaci świętych.

Jak często przy pobożnych fundacjach, tak i w tym wypad$\mathrm{ku}$ biskup Majerczak jako wykonawca pobożnych zapisów, nałożył na kapelana przy szpitalu św. Aleksandra specjalne zobowiązanie odprawienia w każdym roku piętnastu mszy św. czytanych i to:

sześć mszy św. za wszystkich dobroczyńców Domu SS. Mił. Dwie w stałych terminach, w uroiczystość Matki Boskiej Bolesnej i Niepokalanego Poczęcia N.M.P., a cztery w terminach dowolnych, byle raz na kwartał.

Cztery msze św. w poszczególnych kwartałach na intencje SS. Miłosierdzia.

Cztery msze św., co kwartał jedną, w intencji chorych, leżących w szpitalu.

Jedną mszę św. za duszę ś. p. Marianny ${ }^{128} \mathrm{w}$ stałym terminie 11 marca (akt er. $\S \mathrm{XXI}$ ).

Wszelkie inne czynności kapelana, jak odwiedzanie chorych itp. należały do jego osobistej gorliwości.

Za wszystkie obowiązki i posługi duchowne, otrzymywał kapelan szpitala wynagrodzenie $w$ wysokości $R$. 180, czyli $1200 \mathrm{złp}$. rocznie. Kwota ta wypłacana była z ogólnego funduszu SS. Mił.

\section{c) Spowiednicy Sióstr Miłosierdzia}

W każdym żeńskim Domu Zakonnym słuchali spowiedzi św. kapłani, wyznaczeni i zatwierdzeni przez Władzę Duchowną. Prawo klne przewidywało tu osobnych spowiedników, różne i wielorakie $\mathrm{w}$ tym przedmiocie dodając przepisy. Naczelną

125 Do tej kategorii należa SS. Mił.

126 Od sprowadzenia SS. Mił. (13. V. 1862 r.) do 19 . X. 1889 roku prawo to należało dó proboszcza parafii katedralnej; od 20. X. 1889 roku do proboszcza nowo erygwanej parafii św. Wojciecha.

127 Por. A i c h ner S., dz. cyt. 452.

128 Jedna $z$ dobrodziejek Dōmu SS. Mił. 
zasadą, dotyczącą spowiedników zakonnego Domu żeńskiego, był bezwzględny przywilej Ordynariusza, do którego należała aprobata wszystkich spowiedników zakonnic ${ }^{129}$. Z reguły więc spowiadały się one tylko u kapłanów, obdarzonych specjalną do tego władzą ${ }^{130}$.

Stosownie do starej praktyki w Kościele Kat., rozporządzil pap. Benedykt XIV w Konst. „Pastoralis Curae” z dn. 5. VIII. 1748 roku, ,ut pro singulis monialium monasteriis unus dumtaxat confessarius deputetur, qui sacramentales confessiones univensae earum communitatis excipiat". Przepis ten, zaczerpnięty ze wskazań mistrzów życia wewnętrznego i oparty o wielowiekowe doświadczenie Kościoła w dziedzinie kierowania duszami, zapewniał stały, jednolity kierunek i postęp duchowy u spowiadających się. Stąd odnosił się nie tylko do żeńskich zakonów ścisłych o ślubach uroczystych, lecz również ad Instituta votorum simplicium, oraz $z$ reguły do wszelkiego zrzeszenia niewiast, żyjących życiem wspólnym ${ }^{131}$. Spowiednik zwyczajny spełniał swój urząd $\mathrm{z}$ zasady przez trzy lata $\mathrm{i}$ to tak w żeńskich zakonach ścisłych, jak i w zgromadzeniach zakonnych i w stowarzyszeniach kobiet żyjących życiem wspólnym (Ex litt. S. C. De Prop. Fide 20. II. 1877 roku).

Oprócz spowiednika zwyczajnego winien mieć każdy żeński Dom zakonny jednego spowiednika nadzwyczajnego ${ }^{132}$. $\mathrm{Na}$ nowo rozporzadzenie takie wydal pap. Benedykt XIV w Konstytuc.ji „Pastoralis curae” 5. VIII. 1748, zobowiązując wszystkie zakonnice do spowiadania się dwa lub trzy razy $w$ roku u spowiednika nadzwyczajnego, lub przynajmniej do przyjęcia od niego błogosławieństwa i zbawiennych przestróg. Odnosiło się ono tak do zakonnic w zakonach, jak i do wszelkich

${ }^{129}$ „Confessarii sive regulares sive saeculares, quomodocumque exempti, tam ordinarii quam extraordinarii, ad confessiones monialium, etiam Regularibus subiectarum, audiendas, nullatanus deputari valeant, nisi prius ab Episcepo dioecesano idonei iudicentur, et approbationem, quae gratis concedatur, obtineant". Constitutio papae Gregorii XV "Inscrutabili" 5. II. 1622; Por. M o c che gi a i P., Jurisprudentia Ecclesiastica, Tomus I, nr 577.

${ }_{130}$ „Confessarii regulares generaliter approbati ab Episcopo ad personarum saecularum confessiones audiendas, nequaquam censeri approbati ad audiendas confessiones monialium sibi subiectarum, sed egent quoad hoc speciali Episcopi approbatione" Const. pap. Clementis X "Superna" 1670; Por. M o c che gian i P., dz. cyt. Tomus I, nr 578.

131 Por. Ex litt. S. C. De Prop. Fide 20. II. 1877.

132 ,Praeter ordinarium confessorem alius extraordinarins ab Episcopo, aut aliis Superioribus bis, aut ter in anno offeratur, qui omnium confessiones audrie debeat". Cons. Trid. Sess. XXV. cap. 10. De Regul. 
innych niewiast zakonnych, jeżeli tylko żyły wspólnie i miały spowiednika zwyczajnego ${ }^{133}$. Dobro duszy, wolność i spokój sumienia, są motywem, dla którego wszystkie zakonnice powinny indywidualnie stanąc przed spowiednikiem nadzwyczajnym ${ }^{134}$. Podobnie jak spowientik zwyczajny, tak i nadzwyczajny musiał zawsze być zatwierdzony przez Ordynariusza ${ }^{135}$.

Nie w całej rozciągłości i nie wszystkie przepisy prawa ogólnego o spowiednikach, odnosiły się do SS. Mił. Zgromadzenie to korzystało $\mathrm{w}$ tym względzie $\mathrm{z}$ pewnych przywilejów, pokrywających się $z$ postanowieniami św. Wincentego à Paulo. W ten sposób Stolica Apost. respektowała nieprzerwanie regułę świętego założyciela.

$\mathrm{Z}$ prawa ogólnego były szarytki zobowiązane spowiadać się u spowiednika zwyczajnego i nadzwyczajnego. Zachowanie tego zasadniczego rozporządzenia było konieczne dla zabezpieczenia im stałego i jednolitego kierunku wewnętrznego. Poza tym jednak odrębna niż $\mathrm{w}$ innych Zgromadzeniach ustaliła się formalna praktyka w Domach SS. Mił. Przede wszystkim nie udzielał Ordynariusz miejsca spowiednikom szarytek specjalnej jurysdykcji, ani spowiedników nie wyznaczał. Na mocy przywileju Stolicy Apost. ${ }^{136}$, która władze nad całym Zgromadzeniem SS. Mił. oddała Superiorowi Generalnemu XX. Misjonarzy, obu spowiedników tak zwyczajnego, jak i nadzwyczajnego wyznaczał dla szarytek tenże Superior Gene-

\footnotetext{
133 Quamvis Tridentina Synodus de solis claustralibus monialihus in praemisso decreto loquatur, nihilominus enixe commendatur ecclesiarum Antistitibus, ut eandem disciplinae formam observent tam cum allis monialibus, quae licet clausurae legibus minime adscriptae sint, in communitate tamen vivunt, quam cum aliarum quarumcumque mulierum aut puellarum coetibus, seu conservatoriis, quoties tam illae, quam istae unicum ordinarium paetitentiae ministrum a Superioribus designatum habeant. Quaecumgue enim circa moniales in rigorosa clausura viventes cavenda sunt, eadem in aliis quibuscumaue mulieribus, sive reqularibus, sive saecularibus, in communitate aut collegio degentibus. locum habere possunt". Benedictus XIV, Const. „Pastoralis curae” 5. VIII. 1748.

134 „Multi infirmi et imbecilles animo reperiuntur, qui potius eligerent sine sacramentali expiatione ex hac vita migrare, quam ipsa peccata certo alicui sacerdoti a Superiore designato aperire". Bened. XIV, Const. "Pastoralis curae” 5. VIII. 1748. To samo radzi św. Tomasz z Akwinu in Suppl. III q. 8 art. 5 ad 6.

135 Por. Conc. Trid. Sess. XXIII. cap. 15. De Reform.; Greg. XV. .Inscrutabili".

${ }_{136}$ Pius VII. Breve 1804, Breve 22. VI. 1818, Breve 27. XI. 1818; Leo XII, Breve 1827: Leo XIII. Responsio Superiori Generali Congr. Presb. Missionis 25. VI. 1882: Responsio S. Congr. Ep. et Reg. 17. VIII. 1891.
} 
ralny XX. Misjonarzy i to spośród kapłanów, mających zwyczajną jurysdykcję spowiadania kobiet. W ten sposób i Superior XX. Misjonarzy nie udzielał spowiednikom specjalnej jurysdykcji, a tylko dokonywał wyboru tych, którzy już mieli ogólną jurysdykcję biskupa. O wyborze swym donosił następnie Ordynariuszowi. $Z$ zasady spowiednikami SS. Mił. są kapłani świeccy, najczęściej proboszczowie, lub inni kapłani, zajęci w duszpasterstwie, nie zaś kapłani zakonni. Postanowienia takie powziął sam św. Wincenty à Paulo, tłumacząc je tym, że SS. Mił. pracują w świecie i zrzeszone są w zgromadzeniu świeckim; tam zaś, gdzie to jest możliwe, spowiadają się szarytki u XX. Misjonarzy, należących do wspólnej rodziny św. Wincentego à Paulo.

Nie odnosił się też do SS. Mił. ogólny przepis Kościoła o zmianie spowiedników co trzy lata; spowiadały się one $\mathrm{u}$ swych spowiedników $\mathrm{w}$ dowolnym okresie czasu $\mathrm{i}$ to według starego zwylczaju, zatwierdzonego przez Stolice Apost. ${ }^{137}$.

Wpierw, zanim szarytki objęły obowiązki w szpitalu św. Aleksandra, szły po tej linii prośby do bpa kieleckiego X. Majerczaka tak ze strony dyrektora XX. Misjonarzy Prowincji Warszawskiej, jak i S. Wizytatorki. Zawczasu też, dnia 6. III. 1862 roku, przesłał dyrektor XX. Misjonarzy, X. Dmochowski, na ręce bpa przeznaczoną dla przyszłych spowiedników instrukcję, z której mieli ,powziąc jaką taką wiadomość swojego stosunku do sióstr" 138. Prosił przy tym usilnie, aby kierownicy wewnętrznego życia szarytek starali się poznać obowiązki ich powołania przez przestudiowanie żywotów założyciela św. Wincentego i pierwszej fundatorki Ludwiki Le Gras, przez czytanie konferencji św. Wincentego specjalnie do Sióstr wygłoszonych, celem zaczerpnięcia ducha Zgromadzenia i kierowania duszami w sposób pewny i powołaniu zakonnemu najwięcej właściwy.

Szczególnie gorliwie pilnował dyrektor XX. Misjonarzy swego prawa wyboru spowiedników i nie omieszkał bpowi specjalnie tego przypomnieć ${ }^{139}$. Nie znając wszakże kapłanów kieleckich, prosił bpa Majerczaka o wskazanie odpowiednich na ten urząd kandydatów. Po wzajemnym skomunikowaniu

137 „Excepté les maisons des Filles de la Charité, intituées par saint Vincent de Paul, toutes les autres maisons de Soeurs, Colléges et autres Instituts des femmes, sont sujettes à la lai du changement triennal de confesseur". Responsio Em. Card. Praefecti S. C. Ep. et Reg. ad Episcopum Coadiutorem Agrigont., Rom. 18. VIII. 1883.

${ }_{138}{ }_{132} \mathrm{Z}$ pisma dyrektora Misjonarzy $\mathrm{X}$. Dmochowskiego do bkpa Majerczaka $z$ dn, 6. III. $18 \overline{62}$ roku. Akta Kons. Tom I. 
się 'wybớr dokonany został dn. 3. V. 1862 roku, tj. dziesięć dni przed przyjazdem szarytek do Kielc. Obowiązki te pełnili jako pierwsi X. Ignacy Domagalski, kanonik Kolegiaty Kieleckiej w charakterze spowiednika zwyczajnego, oraz X. Julian Ciechanowski, proboszcz z Daleszyc, w Diecezji KieleckoKrakowskiej w charakterze spowiednika nadzwyczajnego. Byli to pierwsi kierownicy życia wewnętrznego dla SS. Mił. przy szpitalu św. Aleksandra w Kielcach. Kompetencje ich dotyczyły wyłącznie spraw sumienia, $\mathrm{z}$ wyłączeniem jakiegokolwiek wpływu czy to na wewnętrzny, czy to na zewnętrzny zarząd Domem.

\section{Zakończenie}

Erekcja Domu Sióstr Miłosierdzia w Kielcach była dziełem celowym i pożytecznym. Potwierdziło to samo życie.

Szpital św. Aleksandra $z$ chwilą objęcia go przez szarytki, wszedł w nowy okres rozwoju. Od razu zyskał większą popularność i rozgłos. Coraz więcej mieszkańców z miasta i okolicy miało $\mathrm{z}$ nim kontakt, wprawdzie $\mathrm{w}$ pierwszym rzędzie przez kaplicę, do której schodzili się na mszę św. Stało się to tym latwiej, że Władze szpitala nie utrudniały i nikomu nie przeszkadzały w uczęszczaniu do kaplicy, a piękno Domu Bożego, obfitość i wystawność wszystkich nabożeństw, także uroczystych, nie wyłączając ceremonii Wielkiego Tygodnia, popularność kaplicy szpitalnej wybitnie zwiększyły.

Prrede wszystkim zaś wzrosło do szpitala kieleckiego zaufanie społeczeństwa. Wierzono $w$ sumienniejszą opiekę i troskliwszą pielęgnację chorych. Stąd liczba ich rosła z każdym rokiem. Pociągało to rozszerzenie oddziałów szpitala, rozbudowę gmachu, powiększenie ilości SS. Mił., lekarzy i służby. Już w pierwszych latach po sprowadzeniu sióstr, leczyło się w szpitalu stale około stu chorych. $Z$ biegiem czasu, $z$ począt$\mathrm{ku}$ w XX, liczba ich dobiegała do dwieście, wreszcie do trzysta osób. Z konieczności też rosła w związku z tym liczba szarytek. Do początkowej liczby pięć, przydzielały Władze Zgromadzenia Prowincji Warszawskiej stopniowo inne tak, że w r. 1910 opiekę nad chorymi sprawowało już dziesięć, a w r. 1940 trzynaście szarytek. Rozbudowa gmachu szpitala, kilkakrotnie inicjowana i odkładana dla braku należytych funduszów, uskuteczniona została ostatecznie w r. 1939 przez dobudowanie całego drugiego i częściowo trzeciego piętra.

Wyraźnie dzięki SS. Mił. zyskały finanse i gospodarka szpitala. Okazało się, że zakonnice, w warunkach w jakich zostały zainstalowane, stanowią przy najlepszych kwalifikacjach per- 
sonel stosunkowo najtańszy i najmniej obciążajacy kasę szpitala. Nawet najskromniejsze pensje $\mathrm{i}$ warunki utrzymania pielęgniarzy i pielęgniarek świeckich, przewyższyłyby znacznie wydatki, jakie kasa szpitalna pokrywała na rzecz szarytek; wydatki te były minimalne wobec faktu, że SS. Mił. od samego początku miały własny fundusz zakładowy, z którego się utrzymywały. Pokaźne kwoty, zaoszczędzone $z$ tego powodu przez szpital, mogły służyć lepszemu wyżywieniu chorych, łatwiejszej i szybszej rozbudowie całej instytucji.

Rozwój pierwszego Domu SS. Mił. w Kielcach nie ograniczył się tylko do szpitala św. Aleksandra. Z czasem objął on Sierociniec, Dom Księży Emerytów i Szpital Dziecięcy.

Było gorącym życzeniem Administratora Diecezji X. Majerczaka, aby zarządowi i opiece SS. Mił. powierzyć możliwie najwcześniej także Sierociniec i Parafialny Dom Starców, zwany Przytułkiem Starców, lub Szpitalem Sw. Trójcy. Z zamiarem swym zwierzał się nie tylko w prywatnych rozmowach, ale ujawnił go publicznie i urzędowo w pismach do przewodniczącego Rady Głównej Laszczyńskiego ${ }^{140}$ i do dyrektora XX Misjonarzy X. Dmochowskiego ${ }^{141}$; formalnie zaś sprecyzowano go $\mathrm{w} \S \mathrm{XX}$ aktu erekcji dn. 10. VIII. 1860 roku. I znów podobnie jak przy zbieraniu zapisów na szpital św. Aleksandra, tak i w tych wypadkach ,Duchowieństwo o nowe fundusze starać się będzie" 142 .

Stosunkowo wcześnie udało się utworzyć Ochronkę pod przewodnictwem szarytek, wprawdzie $\mathrm{z}$ początku $\mathrm{w}$ maluczkich rozmiarach. Założono ją w r. $18644^{143}$. Na cele sierocinca oddały władze szpitala jedną salę szpitalną, nie mającą połączenia z chorymi. Początkowa łączność ochronki ze szpitalem była tym większa, że kierownictwo jej spoczywało w rękach S. Julii Świderskiej, zajętej urzędowo w szpitalu. Sprowadzenie od razu szóstej szarytki dla wyłącznej opieki nad dziećmi, jak chciał bkp Majerczak, nie doiszło do skutku. W r. 1866 przystapiono do budowy osobnego domu dla Sierocińca. W r. 1870, po poświęceniu go przez bkpa Tomasza Kulińskie-

140 8. III. 1860 i 31 . VIII. 1860 roku. Akta Kons. Tom I.

141 2. III. 1862 roku. Tamże.

${ }^{142}$ Słowa bkpa Majerczaka $\mathrm{w}$ piśmie do prezesa Laszczyńskiego

z 31. VIII. 1860 roku. Tamże.

${ }^{143}$ Por. Akta SS. Mił. przy Ochronie św. Wincentego w Kielcach. Niemniej ze wzmianki, uczynionej przez $X$. Majerczaka w liście do prezesa Laszczyńskiego z dnia 8. III. 1860 roku, wynika, ze schronisko dla sierot istnialo w Kielcach już kilka względnie kilkanaście lat. 
go ${ }^{144}$, wobec Gubernatora Kieleckiego Leszczowa i urzędowego opielsuna Ochrony, życzliwie usposobionego Rosjanina Kotlowskiego, uroczyście wprowadzono tam dzieci. Opiekę nad nimi w dalszym ciągu sprawowała S. Swiderska. Z czasem, gdy liczba sierot stale wzrastała, dom kilka razy w r. 1874, 1897,1910 i ostatecznie w r. 1912, rozszerzono i rozbudowano. Od tego czasu znaidowało $\mathrm{w}$ nim schronienie, oraz zapewniono warunki życia i nauki przeciętnie dla $30-40$ dzieci, pozostających pod wyłączną opieką trzech szarytek. W ostatnich latach, zwłaszcza w latach wojennych, ilość sierot przekraczała niekiedy liczbę sto, a zarząd Domu i obowiązki wychowawcze pełniło pięć, przejściowo zaś nawet siedem SS. Mił.

Do Przytułku Starców w Kielcach pod wezwaniem św. Trójcy, nie udało się bkpowi Majerczakowi w ogóle sprowadzić SS. Mił. mimo usilnych starań i zebrania już pewnej na ten cel kwoty. Trudności i przeszkody $\mathrm{w}$ tym względzie są nieznane. Prawdopodobnie nie wystarczały na to przeznaczone na utrzymanie szarytek fundusze, a przede wszystkim nieżyczliwie do tego zamiaru usposobiony był Rząd Rosyjski.

Przez olkres 31 lat, tj. od 1908 roku, prowadzily szar̄ytki w Kielcach Dom XX. Emerytów Diecezji Kieleckiej. Kompetencje ich dotyczyły jedynie całości spraw gospodarczych. Zadanie to spełniały dwie, później trzy i cztery siostry. W pierwszych miesiącach wojny 1939 roku miejsce SS. Mił. zajęły Siostry Służebniczki Najśw. Serca Jezusowego.

Drugą z rzędu największą placówką SS. Mił. w Kielcach stał się z czasem ,Szpital Dziecięcy pod wezwaniem Matki Boskiej Nieustającej Pomocy im. dr Władysława Buszkiewicza”. Za datę założenia szpitala, powszechnie zwanego „Szpitalikiem", należy uważać 16. VII. 1921 rolku. W dniu tym Zarzad Miejski w Kielcach, na mocy uchwały Rady Miejskiej $z$ dn. 20. VI. 1921 roku, oddał na szpital Polsko-Amerykańskiemu Komitetowi Pomocy Dzieciom cały teren zwany „Nowym Łanem", przy ul. Lipowej nr 30. Gdy Komitet ten przerwał w Kielcach swa działalność, zorganizowało sie ,Towarzystwo Przyjaciół Szpitala Dziecięcego", a zarząd Polsko-Amerykańskiego Komitetu, na zasadzie uchwały Rady Miejskiej z dn. 23. II. 1922 roku, przelał wszystkie swe prawa i obowiazki na Tow. Przyiaciół. Odtąd też (w rzeczywistości już od 6. XI. 1921) Tow. Przyjaciól jest jedynym i prawnym właścicielem szpitala, wykonując swój zarząd na podstawie

144 Rządził diecezja kielecką po śmierci bkpa Majerczaka od 24. IX. 1870 do 8 . I. 1907 roku. 
statutu, zatwierdzonego przez Wojewode Kieleckiego dn. 8. XI. 1921 L. Pr. 63601/II, oraz dn. 30. V. 1928. L.B.P. 3615. Otwarcie i poświęcenie szpitala odbyło się 26. XII. 1921 roku.

Zgodnie $\mathrm{z}$ wolą załoźyciela szpitala dra Władysława Buszkiewicza, oraz $\mathrm{z}$ wyraźnym zastrzeżeniem Zarządu Miasta Kielc, na podstawie uchwał Rady Miejskiej $\mathrm{z}$ dn. 20. VI. 1921 roku i 23. II. 1922 roku, oddano zarząd szpitala, cała gospodarke i pielęgnowanie chorych dzieci Siostrom Miłosierdzia reguły św. Wincentego à Paulo. Od samego też początku szarytki prace te wykonywały, stosując się do umowy, zawartej między właścicielem szpitala i Władzami Zgromadzenia Prowincji Warszawskiej w marcu 1922 roku.

Działalnością swą obejmuje ,Szpitalik" całe Województwo Kieleckie ${ }^{145}$. Leczą się $\mathrm{w}$ nim chore dzieci od niemowlęctwa do 14 roku życia bez różnicy płci, w wyjątkowych wypadkach także niemowlęta $\mathrm{z}$ matkami ${ }^{146}$.

Początkowo, gdy Szpital Dziecięcy mieścił się tylko w kil$\mathrm{ku}$ pokojach $\mathrm{w}$ starym folwarcznym domu, liczba chorych nie nie przekraczała z zasady 60 osób ${ }^{147}$, zarząd zaś i opiekę nad nimi sprawowały dwie szarytki. W. mastępnych latach cyfry te znacznie wzrosły. Gdy Tow. Przyjaciół decyzją z dn. 21. VI. 1924 roku postanowiło wybudować główny gmach szpitalny i po ukończeniu budowy oddało go w dn. 2. X. 1927 roku do użytku, liczba leczących się wynosiła: w r. 1925 - 118 osób; w r. 1928 - 534 osoby; w r. 1933 - 726 osób. Tym samym powiększyć się musiał personel szpitalny. Stopniowo funkcje pielęgniarskie pełniło coraz więcej szarytek i pielęgniarek, wreszcie od 1. I. 1928 rokū zajjętych było siedem SS. Mił. z przełożoną S. Julią Borowską, osiem pielęgniareek, sekretarz i dwanaście osób służby niższej. Od tego też czasu ma szpital stałego lekarza. W latach drugiej wojny światowej leczyło się w "Szpitaliku" rocznie około 900 dzieci, pozostających pod opielką jedenastu szarytek.

Cała Instytucja ma pięć oddziałów: dwa dla chorych wewnętrznie, dwa dla chorych zakaźnie i jeden oddział obserwacyjny. Obejmuje glówny gmach szpitalny, pawilon administracyjny i wszystkie potrzebne zabudowania gospodarcze, oraz agród i sad owocowy. Ma też własną kaplicę i kastnicę ${ }^{148}$.

\footnotetext{
145 Statut Tow. Przyjaciół § 2.

${ }_{146}$ Statut Tow. Przyjaciół \& 4.

147 Statut Szpitala Dziecięcego \& III przewidywał 60 łóżek dla dzieci chorych.

${ }_{148}$ Praca nie obejmuje okresu po $1944 \mathrm{r}$.
} 
1. Akta Konsystorskie Kurii Diecezjalnej w Kielcach, a) Szarytki w Kielcach Tom I. od 1857 do 1884 roku, b) Szarytki w Kielcach Tom II. od 1885 do 1941 roku.

2. Akta Sióstr Milosierdzia Domu Prowincjonalnego $w$ Warszawie.

3. Akta Sióstr Mitosierdzia przy szpitalu św. Aleksandra w Kielcach.

4. Akta Sióstr Młosierdzia przy Ochronie św. Wincentego ḋ Paulo w Kielcach.

5. Reguły Córek Miłosierdzia Stug Ubogich Chorych.

6. „Recueil des privilèges et indulgences" a l'usage des Filles de la Charité, Paris 1899.

7. Synodus Dioecesana Kielcensis, Kielce 1927.

8. A i chner S., Compendium Iuris Ecclesiastici, 1874.

9. F a $\mathrm{f}$ a $\mathrm{n}$ i L., De Iure Religiosorum, Romae 1925.

10. Fer r a ri J., Summa Institutionum Canonicarum, Tomus I, II, III, Genuae 1877.

11. I c a rd H., Praelectiones Iuris Canonici, Tomus I, II, III, Parisiis 1962.

12. Lu g a ri A., De Visitatione Sacrorum Limimum, Volumen I, II, III, Romae 1899.

13. Mocchegi a $\mathrm{i}$ P., Iurisprudentia Ecclesiastica, Tomus I, II, III, Friburgi Brisgoviae 1904-1905.

14. Kowalczewski S., Kielce i Okolica, Kielce 1935.

15. We rn z Fr., Ius Decretalium, Tomus I, II, II, Romae 1905-1908.

\section{Résumé}

Erection de la Maison des Soeurs de Charité auprès de l'hôpital du Saint Alexandre à Kielce en $1862 \mathrm{a}$.

L'Administrateur et Vicaire Apostolique du Diocèse de CracovieKíelce, Maciej Majerczak, forma en 1855 l'idée de rendre la protection des malades dans l'hô'pital du Saint Alexandre et l'érection de leur Maison à Kielce aux Soeurs de Charité (Confrérie de la Charité Puellae caritatis). L'évêque donna commencement et mit à exécution dans le courant d'à peu près sept ans tous les travaux préparatoires pour la réalisation de cet oeuvre. Il effectua en particulier une abondante correspondance officielle avec toutes les Institutions compétentes nationales et avec les plus hautes autorités laïques d'Etat et il amassa tout le capital de premier établissement nécessaire pour la dotation des Soeurs de Charité.

L'acte d'érection de la Maison des Soeurs de Charité aupres de I'hôpital de Kielce fut dressé devant un notaire le 10. Août 1860. Cet acte fut dressé conjointement par l'autorité ecclésiastique du diocèse et par le Conseil Administratif des Etablissements de Charité d'arrondissement de Kielce comme autorité supérieure directe d'hôpital, dépendante du Conseil Général Administratif des Etablissements de Charité agissant sur le terrain de toute la Pologne russe.

Das l'acte d'érection on a pris la décision suivante:

1) L'hôpital sera administré comme jusqu'à présent par le Conseil Administratif d'arrondissement qui dirigera toute l'administration, correspondance, comptabilité, tenue des livres. Les Soeurs de Charité par leur part s'occuperont des soins donnés aux malades et du ménage; 
2) Le fonds entier amassé par l'Autorité Ecclésiastique, intégralement séparé du fonds général d'hôpital, est destiné exclusivement à la dotation et à l'entretien de la Maison des Soeurs de Charité. Ce fonds, s'élevant à un montant de 11.250 roubles ou 75.000 zlaty polonais (finalement après legs ultérieurs et collectes s'élevant à un montant de 14.809 roubles 62 kopecks ou $98.730,24$ zloty polonais) restera sous l'administration directe de l'évêque de Kielce et constituera éternellement la propriété légitime et incontestable de la Maison des Soeurs de Charité.

Le clergé du diocèse de Kielce a legué á peu prés tous les legs au profit de cet oeuvre de bienfaisance.

Les autorités du gouvernement ont sanctionnées le 26. Novembre 1861 le capital de premier établissement, déclarant qu'il était suffisant pour la dotation de la Maison des Soeurs de Charité. Le Conseil Général Administratif des Etablissements de Charité comme l'autorité suprême au-dessus des hôpitaux dans tout le pays autorisa en vertu de susdit par la lettre du 16. Décembre 1861 le Canseil Administratif de l'arrondissement à admettre les Soeurs de Charité à l'hôpital du Saint Alexandre à Kielce.

Le président du Conseil Administratif d'arrondissement Erazm Rózycki accomplit à l'hôpital l'installation des soeurs de Charité en nombre de cinq personnes et l'évêque de Kielce Majerczak accomplit le cérémoniel solennel d'église. Ça se passa le 13. Mai 1862.

Quelque peu de tempe après on confia graduellement aux Soeurs de Charité à Kielce les peines dans la Maison des prêtres pensionnaires, dans la crêche pour enfants et đans l'hôpital d'enfants. 